\title{
Work incentives at the extensive and intensive margin in Europe: the role of taxes, benefits and population characteristics
}

\author{
H. Xavier Jara, ${ }^{a}$ Katrin Gasior, ${ }^{b}$ Mattia Makovec ${ }^{\mathrm{c}}$ \\ ${ }^{a}$ Corresponding author, email: hxjara@essex.ac.uk, Institute for Social and Economic Research (ISER), \\ University of Essex, Colchester, United Kingdom, 0000-0001-6648-2653 \\ ${ }^{\mathrm{b}}$ Institute for Social and Economic Research (ISER), University of Essex, Colchester, United Kingdom, 0000- \\ 0003-4342-1174 \\ ${ }^{\mathrm{c}}$ The World Bank, Washington, United States of America
}

\begin{abstract}
Tax and benefit systems play an important role in determining work incentives at both the extensive and the intensive margin of labour supply. The aim of this paper is to provide a comprehensive comparative analysis of work incentives in the European Union and the United Kingdom. Our analysis makes use of microsimulation techniques and representative household surveys to compare the distribution of short- and long-term participation tax rates and marginal effective tax rates across population subgroups. We focus on people currently in work and characterise the population facing low work incentives in each country. Our results highlight the large variation in the distribution of work incentives across Europe, explained not only by differences in the design of tax-benefit systems, but also by the characteristics of the labour force across countries. Unemployment insurance benefits contribute substantially to short-term participation tax rates and explain on average a 20 percentage point difference between work incentives of short- vs. long-term unemployment. Our analysis further highlights the need to use microdata to study differences across countries in terms of the population subgroups facing low incentives to work with the aim to inform the policy debate on potential reforms to make work pay.
\end{abstract}

Keywords: work incentives, extensive margin, intensive margin, social policy, tax-benefit systems

Acknowledgments: This work was supported by the Economic and Social Research Council (ESRC) through the Research Centre on Micro-Social Change (MiSoC) at the University of Essex, grant number ES/L009153/1. The authors are grateful to Katarina Jaksic, Alari Paulus, Matteo Richiardi, Holly Sutherland and two anonymous referess for valuable comments and suggestions. The results presented here are based on EUROMOD version H1.0. EUROMOD is maintained, developed and managed by the Institute for Social and Economic Research (ISER) at the University of Essex, in collaboration with national teams from the EU member states. We are indebted to the many people who have contributed to the development of EUROMOD. The process of extending and updating EUROMOD is financially supported by the European Union Programme for Employment and Social Innovation 'Easi' (2014-2020). We are grateful for access to micro-data from the EU Statistics on Incomes and Living Conditions (EU-SILC) made available by Eurostat under contract 59/2013-EU-SILC-LFS, the Italian version of the EU-SILC (IT-SILC) made available by ISTAT, the Austrian version of the EU-SILC made available by Statistik Austria, the Lithuanian version of the EU-SILC (PGS) made available by the Lithuanian Department of Statistics, the Greek SILC Production Database (PDB) made available by the Greek Statistical Office, additional indicator variables provided by the Polish Central Statistical Office (GUS), national SILC variables made available by the respective NSIs for Estonia, Luxembourg and Slovakia and the Family Resources Survey (FRS), made available by the UK Department of Work and Pensions (DWP) through the UK Data Service. The results and their interpretation are the authors' responsibility and do not necessarily reflect the official position of the World Bank and of its Board of Directors

Conflict of Interest: The authors declare that they have no conflict of interest. 


\section{Introduction}

For more than a decade, "making work pay" (i.e. ensuring that work is financially more attractive than relying solely on publicly provided social benefits) has come at the forefront of the policy agenda in European countries (Figari and Matsaganis, 2016). In this sense, the design of tax-benefit systems plays an important role as it might influence the incentive to take up (or give up) a job and to work or earn more (or less). Providing a description of work incentives embedded in tax-benefit systems at the population level in Europe and identifying those groups with low work incentives is a necessary first step in order to assess the effectiveness of potential reforms to make work pay and to target labour market activation policies on these groups.

The analysis of the role of tax-benefit systems on work incentives has focused on two different margins: the extensive margin of labour supply (incentives to take up or give up work) and the intensive margin (incentives to work or earn more or less). At the extensive margin, the generosity and duration of unemployment insurance or social assistance benefits have often been associated with disincentives to take up work for certain population subgroups. At the intensive margin, high marginal tax rates have been discussed as factors reducing incentives to work or earn more.

Commonly used indicators of work incentives are usually based on synthetic (or hypothetical) households (see OECD, 2016). Such indicators are particularly useful to analyse the presence of unemployment or poverty traps among specific family types. However, they do not allow us to provide a full representation of the distribution of work incentives in the population, or to identify which population subgroups are more likely to be affected by low work incentives. The aim of this paper is therefore to provide a comparative and comprehensive analysis of work incentives at the extensive and intensive margin in the European Union (EU) and the United Kingdom (UK) ${ }^{1}$, based on representative household microdata. In particular, we use EUROMOD, the European tax-benefit microsimulation model, to compare the short- and long-term participation tax rates (PTRs) and marginal effective tax rates (METRs) in 2017 for individuals currently in work in European countries. Further, our analysis provides a characterisation of individuals facing low work incentives, and assesses how labour market incentives have changed over time across countries due to changes in tax-benefit policies (i.e. keeping the population fixed), in the last ten years.

Our focus on individuals in work is in line with the growing literature analysing the changing nature of jobs, which has highlighted the importance of studying the situation of workers. Increased automation has put jobs in certain occupations at risk (Goos and Salomons 2009; OECD 2015). There has also been an increase in non-standard forms of employment such as self-employment, part-time work and temporary jobs. Moreover, many European countries have experienced a rise in in-work poverty rates (Eurofound 2017; Lohmann and Marx 2018). Our analysis is in line with these studies and aims to focus on another dimension related to the situation of people in work, namely the financial incentives to work inherent in the tax-benefit system for this population. The focus on individuals currently in work allows us to assess on the one hand the potential unemployment traps workers might face in case they lose their jobs, and on the other hand to consider incentives at the intensive margin, which are important to identify individuals facing poverty traps while in work.

Recent studies, making use of representative household microdata, have focused on the effect of tax-benefit systems on work incentives in single countries. Pirttillä and Selin (2011) provide a description of METRs and PTRs in Sweden over the period 2006-2010. Decoster et al. (2015) study the effect of changes in tax-benefit systems on work incentives at the extensive and intensive margin in Belgium over the period 1992-2012. Bartels and Pestel (2016) compute short- and long-term PTRs in Germany over the period 1993-2010 and assess the importance of work incentives in the decision of individuals to take up work. Navicke et al. (2016) study the effect of potential reforms to unemployment and social assistance benefits on financial incentives to work at the extensive margin in Lithuania. Recent cross-country studies using microdata are, on the other hand, scarce. Studies by Immervoll, Kleven, Kreiner and Saez (2007), Immervoll, Kleven, Kreiner and Verdelin (2011) and O'Donoghue (2011) have, for instance, looked at work incentives across European countries but for tax-benefit rules in place in 1998. More recently, Jara and Tumino (2013) present a comparison of work incentives for the EU27 (including the UK, excluding Croatia), but focusing only on the intensive margin of labour supply. Finally,

\footnotetext{
${ }^{1}$ The analysis is based on 2017 when the United Kingdom was still member of the European Union.
} 
Collado, Cantillon, Van den Bosch, Goedemé and Vandelannoote (2019) calculate the cost of reducing the poverty gap while holding work incentives at the extensive margin constant but only in three countries: Belgium, Denmark and the UK.

In summary, our research contributes to the literature in four different ways. First, it provides an up-to-date comparative analysis of work incentives at the extensive and intensive margin for all European countries, based on representative household microdata which enables us to assess the heterogeneity of work incentives across population subgroups. Second, we estimate both short- and long-term (when entitlement to unemployment insurance benefits has been exhausted) PTRs in order to highlight the extent to which unemployment insurance and social assistance benefits affect work incentives at the extensive margin across countries, vis-à-vis income taxes and social insurance contributions. Third, we provide a portrait of the individuals facing low work incentives at the extensive and intensive margin across countries. Fourth, we assess how labour market incentives have evolved across countries during the last decade by holding population and labour market characteristics constant and focusing on the policy effect.

Our results highlight a number of interesting findings. First, there is a large variation in the distribution of work incentives, at the population level, across countries, emphasising the importance of using representative microdata in the analysis. On the one hand, cross-country differences in the distribution of work incentives reflect differences in the design of tax-benefit systems and, on the other hand, differences in the composition of the labour market across countries. We provide a sensitivity analysis where we test the extent to which work incentives are affected by changes in the population structure. Second, our assessment of short- and long-term PTRs highlights the importance of unemployment insurance benefits on work incentives at the extensive margin. Long-term PTRs are on average 20 percentage points lower than short-term PTRs. Third, in general, employees and workers at the bottom of the earnings distribution face the highest short- and long-term PTRs, which might be related to the existence of lower limits for unemployment insurance benefits (short-term) or social assistance (long-term). At the intensive margin, the highest METRs are observed for high earners, which is most likely related to the progressivity of direct taxes in most countries. A comparison over time furthermore shows that these results have been quite stable over the last 10 years in most countries, which can be attributed to a certain path-dependency of social policy.

The remainder of this paper is structured as follows. Section 2 discusses the methodology followed to calculate indicators of work incentives at the extensive and intensive margin using the microsimulation model EUROMOD, based on representative household microdata. Section 3 presents the results focusing on the distribution of work incentives across countries, the composition of work incentives by income source, the variation of work incentives across different population subgroups, a description of the characteristics of individuals facing low work incentives in each country, and an analysis of the evolution of labour market incentives over time. Finally, section 4 concludes by summarising the main findings and discussing their policy implications.

\section{Methodology}

\subsection{EUROMOD and the data}

Our analysis makes use of EUROMOD (version H1.0), the tax-benefit microsimulation model for the European Union. EUROMOD simulates direct taxes and social insurance contributions liabilities, as well as cash benefit entitlements for the household population of all EU countries and the UK. ${ }^{2}$ The underlying microdata used for our simulations in EUROMOD comes from the 2015 European Union Statistics on Income and Living Condition (EU-SILC) for all countries except the UK, where the 2014/2015 Family Resources Survey (FRS) is used. In this study, the tax and benefit rules used are those in place on the 30th of June 2017, which we refer to as 2017 policy systems. Market income and non-simulated income components in the data have been updated to 2017 according

\footnotetext{
${ }^{2}$ See Sutherland and Figari (2013) for further information.
} 
to actual changes in prices and incomes over the relevant period. No adjustment is made for changes in population composition between 2015 and 2017.

The tax-benefit microsimulation model EUROMOD is a unique tool to carry out distributional analysis and measure labour market incentives implied by tax/benefits systems for all European countries. The EU together with the UK are also a perfect laboratory in which to study these issues, since countries vary widely in the generosity of unemployment and social assistance benefits, which will affect incentives at the extensive margin, but also in the progressivity of income taxes and the design of social insurance contributions, which will be reflected in differences in work incentives at the intensive margin. Belgium, Germany, Finland, Austria and Bulgaria, for instance, are characterised by generous unemployment insurance with a payment of around 60 percent of previous earnings and a duration of 12 months or more. In Hungary, unemployment insurance also represents 60 percent of previous earnings but is only paid for up to three months. The payment is lower in Lithuania, which is made of a fixed basic part plus a variable part starting at 40 percent of previous earnings and going down to 20 percent after three months. Unemployment insurance is the least generous in the UK with a flat payment between $£ 58$ and $£ 73$ per week for a duration of six months. Unemployment assistance is also available in Germany, Hungary, Austria and Finland, among others, which can act as a top-up or complement unemployment insurance when this is exhausted, or be available for individuals who are not eligible for unemployment insurance. Furthermore, many countries provide national social assistance benefits in order to guarantee a minimum level of income to low-income households (guaranteed minimum income benefits). The exception is Italy which introduced a national-level guaranteed minimum income benefit in January 2018, not modelled in the current 2017 tax-benefit system.

In terms of income tax, the degree of progressivity varies across countries, with several cases of flat-tax systems, such as Bulgaria, Hungary, Lithuania, Estonia. Other characteristics of the tax-benefit system will also reflect differences in work incentives across countries, such as the existence of in-work benefits (particularly important in the UK and Hungary). Finally, countries also vary substantially in terms of labour market characteristics (e.g. the share of self-employed or part-time workers), the distribution of earnings and household composition (e.g. presence of secondary earners or children), which together with the design of tax-benefit systems will affect the distribution of work incentives at the extensive and intensive margin.

The tax-benefit model EUROMOD is used to calculate work incentives at the extensive and intensive margin for individuals currently in work. As previously mentioned, the focus on individuals currently in work allows us to consider incentives at the intensive margin and to provide insights into potential unemployment traps they might face if they lose their jobs. At the extensive margin, Participation Tax Rates (PTRs) are calculated by means of simulating transitions from work into unemployment. Our analysis considers PTRs rather than net replacement rates because net replacement rates can be significantly influenced by the market income of other individuals in the household, whereas PTRs allow us to abstract from such effects (O'Donoghue 2011). Thus, PTRs are a useful indicator of incentives to work at the extensive margin in order to highlight the role played by the tax-benefit system in the formation of incentives to work. Moreover, our analysis provides a description of both short- and long-term PTRs in order to highlight the role played by unemployment insurance (and social assistance) schemes in different countries. In our analysis, long-term PTRs are defined based on disposable income out of work when entitlement to unemployment insurance benefits has been exhausted. At the intensive margin, Marginal Effective Tax Rates (METRs) are computed assuming a marginal increase in earnings. For both PTR and METR, it is assumed that behaviour of other household members does not change when a person becomes unemployed or when their earnings increase.

We restrict our sample of analysis to individuals with positive earnings, aged 18 to 65, excluding those in fulltime education or retirement. Table 8 in Appendix $\mathrm{C}$ presents the characteristics of the samples in each country. For the purpose of our analysis, we further assume full compliance in the sense that adjustments for tax evasion and benefit non-take-up are not taken into account for the calculation of work incentives. As such, the results should be interpreted as the "intended effect" of the tax and benefit system on labour market incentives. Finally, it is worth mentioning that despite EUROMOD's flexibility in simulating a variety of tax-benefit instruments, the effect of certain policies on work incentives might be difficult to capture. For instance, eligibility for temporary measures to stimulate employment consisting of benefit payments over a short number of months while in work might be complex to simulate. As a result, such benefits might be either taken directly from the data (not 
simulated) or entitlement might not be fully captured, meaning that their effect on work incentives might be underestimated. In general, this type of benefits affects only a relatively small share of the population.

\subsection{Calculation of Participation Tax Rates (PTRs)}

The participation tax rate (PTR) is an indicator of the financial incentives to take-up or to give up work, implied by the tax-benefit system. As such, PTRs are an indicator of incentives at the extensive margin of labour supply. In particular, PTR can be defined as the proportion of earnings taken away by increased taxes and social insurance contributions or by reduced benefits when transitions from unemployment to work are simulated. Alternatively, PTR can also be interpreted as the proportion of earnings kept in the form of increased benefits or reduced taxes and social insurance contributions when transitions from work into unemployment are considered.

The approach used in this paper to calculate PTRs consists of moving people currently in work (employment or self-employment) in the data into unemployment and re-calculating their new disposable income by means of the microsimulation model EUROMOD, hence capturing the implications of tax and benefit systems under their new labour market status. As such, we interpret PTRs as the proportion of earnings kept in the form of benefits or reduced taxes and social insurance contributions. The rationale for our focus on transitions from work into unemployment is threefold. First, simulating transitions from unemployment or inactivity into work would require imposing a number of important assumptions in order to simulate disposable income in work. For instance, wages as well as hours of work and employment status (i.e. employee or self-employed) would need to be imputed for non-workers, and in some cases industry or occupation if tax-benefit rules depend on such characteristics. Second, focusing on those currently in work allows us to consider a large share of the working-age population rather than the selected group of unemployed which varies greatly in size across countries. Third, high PTRs do not necessarily translate into a higher share of unemployed as these indicators do not reflect individual preferences for work (but rather financial incentives implied by the tax-benefit system) and the decision on whether someone enters employment is not necessarily voluntary but driven by labour market constraints. Thus, measured like this, PTRs are not only a measure of work incentives but also a measure of income protection in the case of unemployment for a large population group. In addition, we include results for the 10 percent of those currently in employment most at risk of unemployment which provides a proxy for those currently in unemployment and how results would look like if we were to transition currently unemployed into employment.

The approach used to simulate transitions from work to unemployment in EUROMOD is described in detail in Appendix A.

More formally, the Participation Tax Rate for individual i in household $\mathrm{h}$ can be expressed as:

$$
\mathrm{PTR}_{\mathrm{i}}=1-\frac{\mathrm{Y}_{\mathrm{h}}^{\mathrm{W}_{\mathrm{i}}}-\mathrm{Y}_{\mathrm{h}}^{\mathrm{U}_{\mathrm{i}}}}{\mathrm{E}_{\mathrm{i}}},
$$

where $\mathrm{E}_{\mathrm{i}}$ represents gross earnings of individual $\mathrm{i}$ when they are in work, $\mathrm{Y}_{\mathrm{h}}^{\mathrm{W}_{\mathrm{i}}}$ represents household disposable income when individual $\mathrm{i}$ is in work $\left(\mathrm{W}_{\mathrm{i}}\right)$, and $\mathrm{Y}_{\mathrm{h}}^{\mathrm{U}_{\mathrm{i}}}$ represents household disposable income when individual $\mathrm{i}$ is in unemployment $\left(\mathrm{U}_{\mathrm{i}}\right)$. In the case of households with multiple earners, PTRs are calculated for each earner in the household separately, assuming that the behaviour of other earners and household members does not change when a person becomes unemployed.

The role of different income sources in work incentives at the extensive margin can be described by decomposing household disposable income as the arithmetical sum of original incomes (O) (incomes before any tax and transfer), benefits and pensions (B), minus taxes ( $T$ ) and social insurance contributions (S). Equation (1) can hence be rewritten as:

$$
\mathrm{PTR}_{\mathrm{i}}=1-\frac{\mathrm{Y}_{\mathrm{h}}^{\mathrm{W}_{\mathrm{i}}}-\mathrm{Y}_{\mathrm{h}}^{\mathrm{U}_{\mathrm{i}}}}{\mathrm{E}_{\mathrm{i}}}=1-\left(\frac{\Delta \mathrm{O}_{\mathrm{h}}+\Delta \mathrm{B}_{\mathrm{h}}-\Delta \mathrm{T}_{\mathrm{h}}-\Delta \mathrm{S}_{\mathrm{h}}}{\mathrm{E}_{\mathrm{i}}}\right),
$$


where $\Delta \mathrm{B}_{\mathrm{h}}$ represents, for instance, the difference between household benefits and pensions when individual $\mathrm{i}$ is in work and when individual $\mathrm{i}$ is unemployed. Moreover, since the change in original incomes is equal to the change in earnings, the expression can be further rewritten as:

$$
\mathrm{PTR}_{\mathrm{i}}=-\left(\frac{\Delta \mathrm{B}_{\mathrm{h}}-\Delta \mathrm{T}_{\mathrm{h}}-\Delta \mathrm{S}_{\mathrm{h}}}{\mathrm{E}_{\mathrm{i}}}\right)=\mathrm{PTR}_{\mathrm{i}}^{\mathrm{B}}+\mathrm{PTR}_{\mathrm{i}}^{\mathrm{T}}+\mathrm{PTR}_{\mathrm{i}}^{\mathrm{S}},
$$

where the first component represents the change in benefits and pensions at the household level when individual i enters unemployment, as a percentage of individual i's earnings; and the last two components report, respectively, the change in taxes and in social insurance contributions at the household level when individual i enters unemployment, as a percentage of earnings. In our analysis of PTRs, we further decompose benefits into three components: (i) unemployment benefits, including both unemployment insurance and unemployment assistance schemes; (ii) social assistance benefits, including minimum income schemes, housing benefits, etc.; and (iii) other benefits, which include family and education benefits, in-work benefits (such as the Working Tax Credit in the UK), disability benefits (such as health, disability and invalidity benefits) and public pensions. The analysis only takes simulated benefits into account while non-simulated benefits, i.e. taken from the input data due to lack of information to simulate them, cannot be adjusted to the new labour market status (see Appendix B for information on simulated other benefits). Pensions only contribute to other benefits on very rare occasions as pensioners are by definition excluded from our analysis and the pension rights of other household members are only affected if the means-test is based on employment income from other household members.

Decomposing benefits into unemployment, social assistance and other benefits is particularly important in the analysis of short- and long-term PTRs. The role of unemployment insurance benefits would be particularly important for short-term PTRs, while social assistance benefits would play a larger role in long-term PTRs, which are defined here based on disposable income out of work when entitlement to unemployment insurance benefits has been exhausted.

In principle, one would expect PTRs to range between 0 and 100 percent. While a PTR of 100 indicates a low work incentive as the income would remain the same, a PTR of 0 indicates a high work incentive. However, specific features of tax and benefit systems could result in PTRs taking values above 100 percent. For instance, the presence of lower limits of unemployment insurance schemes (minimum payment amounts for those satisfying the minimum required eligibility conditions) could result in disposable income in unemployment being higher than disposable income in work for low earners. Negative PTRs could be, for instance, the result of losing some type of tax credits when entering unemployment. Although PTRs outside the range of 0 to 100 percent are plausible, in our analysis we exclude the top percentile of the distribution of PTRs if the PTR is above 150 percent and the lowest percentile if the PTR is negative. This restriction is chosen in order to reduce the risk of our calculations being biased by "outliers", especially when we consider PTRs by earning quintiles and for different population subgroups. ${ }^{3}$

\subsection{Calculation of Marginal Effective Tax Rates (METRs)}

The marginal effective tax rate (METR) is an indicator of the financial incentives to work more (at a given wage rate) or earn more (i.e. increase effort at a given number of hours of work). As such, METRs are a popular indicator of the incentives faced by workers on the intensive margin of labour supply. In particular, the METR measures the proportion of a marginal increase in earnings that would be taxed away due to social insurance contributions, taxes and loss of benefit entitlement.

The calculations of METRs in EUROMOD are described in detail by Jara and Tumino (2013) and use the following steps: first, household disposable income is calculated; then, for each earner in the household, in turn, individual earnings are increased by 3 percent and the corresponding household disposable incomes are

\footnotetext{
${ }^{3}$ A similar procedure is suggested by Jara and Tumino (2013) in their analysis of marginal effective tax rates.
} 
computed. ${ }^{4}$ METRs are therefore specific to each earner in the household. More formally, the marginal effective tax rate of individual $\mathrm{i}$ in household $\mathrm{h}$ is given by:

$$
\operatorname{METR}_{\mathrm{i}}=1-\frac{\mathrm{Y}_{\mathrm{h}}^{1}-\mathrm{Y}_{\mathrm{h}}^{0}}{\mathrm{E}_{\mathrm{i}}^{1}-\mathrm{E}_{\mathrm{i}}^{0}},
$$

where the numerator measures the change in household disposable income before $\left(\mathrm{Y}_{h}^{0}\right)$ and after $\left(\mathrm{Y}_{h}^{1}\right)$ the increase in individual earnings $\left(E_{\mathrm{i}}\right)$ and the denominator is equal to the increase in earnings itself.

As in the case of PTR, the role of different income components on METR can be calculated by decomposing household disposable income as the sum of original incomes $(\mathrm{O})$, benefits and pensions (B), minus taxes (T) and social insurance contributions (S). Equation (4) can be then rewritten as:

$$
\operatorname{METR}_{\mathrm{i}}=1-\frac{\Delta \mathrm{Y}_{\mathrm{h}}}{\Delta \mathrm{E}_{\mathrm{i}}}=1-\left(\frac{\Delta \mathrm{O}_{\mathrm{h}}+\Delta \mathrm{B}_{\mathrm{h}}-\Delta \mathrm{T}_{\mathrm{h}}-\Delta \mathrm{S}_{\mathrm{h}}}{\Delta \mathrm{E}_{\mathrm{i}}}\right),
$$

where now $\Delta \mathrm{B}_{\mathrm{h}}$ represents the difference between household benefits and pensions before and after the increase in individual i's earnings. Since the change in original incomes is equal to the change in earnings, we obtain:

$$
\operatorname{METR}_{\mathrm{i}}=-\left(\frac{\Delta \mathrm{B}_{\mathrm{h}}-\Delta \mathrm{T}_{\mathrm{h}}-\Delta \mathrm{S}_{\mathrm{h}}}{\Delta \mathrm{E}_{\mathrm{i}}}\right)=\operatorname{METR}_{\mathrm{i}}^{\mathrm{B}}+\operatorname{METR}_{\mathrm{i}}^{\mathrm{T}}+\operatorname{METR}_{\mathrm{i}}^{\mathrm{S}},
$$

where the first component represents the change in benefits and pensions at the household level as a percentage of the earnings increase and the last two components represent the change in taxes and social insurance contributions as a percentage of the earnings increase.

METRs would also be expected to take values between 0 and 100 percent. A value of 0 means that individuals keep all of the earnings increase, while 100 means that the total increase is taken away due to higher taxation, additional social insurance contributions or the loss of benefit entitlements. However, certain aspects of tax and benefit rules could result in METRs outside this range. METRs above 100 could, for instance, be related to the loss of some benefit entitlement, which would overcome the marginal increase in earnings. Negative values of METRs could, on the other hand, arise from tax allowances or benefit entitlements paid to people with income above a given threshold. Individuals crossing the threshold after an increase in earnings would experience a larger increase in household disposable income, resulting in negative METR (Immervoll 2004). In our calculations, we exclude the top percentile of the METR distribution if the METR is above 150 percent and the lowest percentile if the METR is negative, in order to reduce the risk of our results being biased by "outliers".

\section{Results}

This section presents results focusing on five aspects drawing from the use of microdata for the analysis of work incentives. First, the distribution of PTRs and METRs across the population of analysis is discussed in a crosscountry perspective. Then, work incentives are decomposed by three main income sources: taxes, social insurance contributions and benefits. Third, the use of microdata is exploited to present work incentive indicators for different population subgroups and to discuss their variation across countries. Fourth, a portrait of people facing low work incentives at the extensive and extensive margin in each country is provided. The fifth part of the analysis presents an overview of the main evolution of work incentives in the EU and the UK over the last decade.

\footnotetext{
${ }^{4}$ As such, we calculate the incentives to earn more rather than to work more, as we do not increase hours of work. The marginal increase of 3 percent in earnings roughly corresponds to an extra hour of work for a person working 40 hours per week (Jara and Tumino 2013). The choice of a marginal increase in earnings rather than an increase in hours of work is motivated by the lack of precise information about working hours in EU-SILC (i.e mismatch between the income reference period and the reference period for labour market characteristics). In some countries, our measure of METR would not enable us to capture the fact that working more hours might result in a loss of entitlement to certain social benefits. Social benefits, where eligibility depends on the number of hours worked, exist in Denmark (social assistance), Germany (unemployment benefit I and parental leave benefits), Ireland (Supplementary Welfare Allowance), France (tax credits), Slovenia (social assistance) and the UK (Income Support and Working Tax Credit).
} 


\subsection{Comparing PTRs and METRs across countries}

This section discusses the general level and distribution of short-term PTRs, long-term PTRs and METRs with a focus on mean and median work incentives as well as the inter-quartile range between the $75^{\text {th }}$ and $25^{\text {th }}$ percentile of each indicator. The analysis reveals the advantage of using household representative data to calculate work incentives, and the results illustrate the significant variation in the distributions of short- and long-term PTRs and METRs across countries.

The first part of this section focuses on short-term PTRs, namely the rates during the first year of unemployment, presented in the first set of columns in Table 1. Results show the high variation of work incentives across countries: the highest average short-term PTRs can be found in Luxembourg, followed by France, Denmark, Belgium, Portugal, Finland and Germany. In general, these countries are characterised by quite generous unemployment insurance schemes with a strong contributory component, which can explain high PTRs in the short-term. The lowest average long-term PTRs are observed on the other hand in the UK, Romania, Cyprus, Lithuania and Malta. In the latter countries, the proportion of earnings that is kept in the form of increased benefits or lower taxes when an individual becomes unemployed is less than 50 percent. Thus, individuals have on average a higher incentive to be employed. On the other hand, rewards to work are relatively small in countries with high PTRs which in turn means that these countries provide quite a generous safety net in case of unemployment and/or that a substantial amount of gross wages are taxed away. In Luxembourg for example, reduced taxes and increased benefit entitlements would mean that an employee would receive more than 80 percent of their earnings in case of unemployment, on average.

The association between work incentives and labour market outcomes has been of particular interest in literature. Overly high PTR might influence decisions to give up work, which would translate into higher rates of unemployment. Figure 6 in Appendix C plots short-term PTR against unemployment rates across countries. The left-hand panel presents average short-term PTR across the whole population, which show an extremely low correlation (0.034) with unemployment rates. The right-hand panel of Figure 6 focuses on average short-term PTR across individuals with low earnings (i.e. first quintile of the earnings distribution in each country), which are more likely to be at risk of unemployment. In this case, the positive correlation with unemployment rates is higher (0.278) but still relatively weak. The modest correlation between short-term PTR and unemployment rates reflects the fact that, in addition to the design of tax-benefit systems, other factors might affect individuals' choices in the labour market, for instance labour demand constraints. We come back to this discussion in the conclusion.

Table 1 also illustrates the importance of considering the distribution of PTRs rather than focusing on the average or median values only. The inter-quartiles presented in the table for each country highlight that, overall, national tax and benefit systems contribute to quite different distributions of PTRs across countries. Results show that countries with relatively similar mean PTRs might exhibit different distributions, as in the case of Denmark and Portugal, for instance. Further, the table shows that substantial dispersion of PTRs can occur at high (Denmark and Portugal), intermediate (Sweden, Netherlands, Greece, Bulgaria and Italy) or low (Ireland, Poland, the UK and Malta) average levels of PTRs.

Results also show the extent to which the median of the PTRs distribution differs from the mean. We observe a higher concentration of people with higher-than-average work disincentives in countries where the median is higher than the mean. Generally, this is the case in countries with relatively high average short-term PTRs, and in particular in the Netherlands, Bulgaria and Italy. On the other hand, countries with relatively low average PTRs also show greater concentration towards the bottom of the distribution (the median is lower than the mean), as in the case of Malta and Spain.

The PTRs presented so far show the financial incentive for working versus not working during the first year of unemployment. However, individuals may base their labour supply decision not only on the short-term change in income but may also take a longer time horizon into account (Bartels and Pestel 2016). Once unemployed, individuals might also be faced with long-term unemployment and need to rely on the safety net provided after receipt of unemployment insurance is exhausted. We present long-term PTRs and discuss their difference to shortterm PTRs in the following paragraphs. In our analysis, long-term PTRs are defined based on disposable income out of work when entitlement to unemployment insurance benefits has been exhausted. 
Table 1 Distribution of short/long-term PTRs and METRs in 2017. Note: countries in alphabetical order (based on their national language). See also Figure 7-9 in the Appendix for a graphical representation of the table and Tables 12-14 for a sensitivity analysis with reweighted results. Source: own calculations using EUROMOD version $\mathrm{H} 1.0$

\begin{tabular}{|c|c|c|c|c|c|c|c|c|c|c|c|c|}
\hline & \multirow{2}{*}{$\begin{array}{r}\text { A. } \\
\text { Mean }\end{array}$} & \multicolumn{2}{|c|}{ Short-term PTR } & \multirow[b]{2}{*}{ p75 } & \multirow[b]{2}{*}{ Mean } & \multicolumn{3}{|c|}{ B. Long-term PTR } & \multirow[b]{2}{*}{ Mean } & \multicolumn{3}{|c|}{ C. METR } \\
\hline & & Median & p25 & & & Median & p25 & p75 & & Median & p25 & p75 \\
\hline $\mathrm{BE}$ & 74.3 & 77.8 & 70.9 & 83.9 & 48.1 & 47.6 & 40.6 & 55.2 & 54.2 & 55.3 & 53.5 & 59.7 \\
\hline BG & 61.8 & 67.0 & 50.0 & 77.0 & 25.3 & 22.0 & 22.0 & 27.8 & 21.9 & 22.0 & 22.0 & 22.0 \\
\hline $\mathrm{CZ}$ & 49.4 & 48.2 & 41.2 & 56.6 & 34.8 & 31.1 & 25.2 & 40.3 & 28.5 & 31.1 & 31.1 & 31.1 \\
\hline DK & 75.2 & 74.9 & 66.8 & 84.3 & 56.8 & 49.8 & 41.6 & 66.0 & 46.0 & 42.8 & 40.4 & 55.8 \\
\hline DE & 70.8 & 74.8 & 69.9 & 78.7 & 43.5 & 42.4 & 33.3 & 53.4 & 45.3 & 44.5 & 40.8 & 49.2 \\
\hline $\mathrm{EE}$ & 51.4 & 55.5 & 44.9 & 57.1 & 34.5 & 30.7 & 26.4 & 38.0 & 23.1 & 22.9 & 21.3 & 22.9 \\
\hline IE & 47.5 & 45.0 & 36.6 & 53.0 & 44.2 & 43.8 & 31.3 & 52.9 & 41.2 & 50.0 & 29.0 & 53.0 \\
\hline EL & 61.7 & 55.7 & 49.7 & 66.8 & 45.8 & 42.8 & 33.5 & 54.2 & 32.6 & 36.0 & 16.5 & 40.8 \\
\hline ES & 49.8 & 44.0 & 37.5 & 55.7 & 32.1 & 28.6 & 16.1 & 38.6 & 23.5 & 28.8 & 6.3 & 34.8 \\
\hline FR & 77.3 & 79.6 & 75.9 & 82.6 & 39.9 & 38.7 & 30.1 & 49.1 & 39.5 & 37.1 & 22.3 & 43.5 \\
\hline HR & 53.9 & 56.0 & 46.7 & 63.8 & 28.7 & 26.9 & 21.6 & 32.7 & 28.1 & 20.0 & 20.0 & 41.5 \\
\hline IT & 56.6 & 64.8 & 42.0 & 70.7 & 24.1 & 25.0 & 15.6 & 34.1 & 40.2 & 43.4 & 35.6 & 49.1 \\
\hline CY & 43.4 & 39.3 & 36.8 & 46.6 & 30.7 & 20.6 & 9.1 & 45.7 & 23.4 & 13.2 & 7.8 & 30.9 \\
\hline LV & 53.2 & 58.1 & 50.4 & 62.3 & 30.2 & 28.5 & 25.0 & 30.4 & 31.1 & 31.1 & 31.1 & 32.9 \\
\hline LT & 43.3 & 41.6 & 34.8 & 49.5 & 24.8 & 22.4 & 15.8 & 29.5 & 26.6 & 31.5 & 24.0 & 31.5 \\
\hline LU & 82.8 & 87.8 & 82.7 & 90.0 & 43.6 & 42.2 & 28.2 & 56.1 & 43.7 & 43.5 & 28.9 & 50.0 \\
\hline HU & 51.1 & 47.1 & 41.9 & 51.0 & 41.5 & 34.5 & 33.9 & 44.0 & 29.1 & 34.5 & 34.5 & 34.5 \\
\hline MT & 38.8 & 30.5 & 26.2 & 48.5 & 34.9 & 25.4 & 20.3 & 47.8 & 25.8 & 25.0 & 23.2 & 31.1 \\
\hline NL & 64.0 & 71.4 & 57.2 & 78.4 & 32.7 & 29.1 & 18.3 & 39.4 & 41.3 & 49.2 & 34.8 & 49.2 \\
\hline AT & 68.3 & 68.6 & 64.9 & 71.4 & 47.8 & 45.0 & 33.9 & 57.0 & 42.3 & 43.3 & 36.8 & 48.2 \\
\hline PL & 46.4 & 42.5 & 36.8 & 52.4 & 33.9 & 29.7 & 27.4 & 38.6 & 29.5 & 30.3 & 29.2 & 30.3 \\
\hline PT & 74.0 & 79.2 & 72.8 & 86.9 & 42.3 & 36.7 & 21.6 & 56.7 & 31.0 & 35.8 & 11.0 & 39.5 \\
\hline RO & 44.4 & 49.3 & 41.5 & 54.8 & 29.1 & 29.0 & 25.6 & 34.5 & 33.0 & 29.9 & 29.9 & 33.1 \\
\hline SI & 59.0 & 58.1 & 49.7 & 67.8 & 39.6 & 36.3 & 30.5 & 46.0 & 39.7 & 38.6 & 30.6 & 42.2 \\
\hline SK & 48.6 & 49.3 & 46.0 & 50.1 & 37.8 & 30.8 & 28.2 & 45.3 & 32.8 & 29.9 & 29.9 & 34.0 \\
\hline FI & 70.6 & 70.8 & 68.9 & 74.2 & 56.0 & 51.6 & 48.4 & 60.0 & 45.6 & 46.9 & 39.5 & 50.5 \\
\hline SE & 66.9 & 64.6 & 59.3 & 73.4 & 30.7 & 26.0 & 23.3 & 34.4 & 38.7 & 32.3 & 28.8 & 52.3 \\
\hline UK & 45.0 & 40.7 & 35.1 & 53.4 & 35.7 & 32.8 & 22.3 & 47.1 & 38.9 & 34.4 & 32.0 & 42.5 \\
\hline
\end{tabular}

The second set of columns in Table 1 shows that long-term PTRs are substantially lower than short-term PTRs across countries. The difference between short- and long-term PTRs is driven by the effect of unemployment insurance schemes (see section 3.2), which provide a large degree of income protection in the short-run but in general are of limited duration. The finding is particularly important as, with a few exceptions, most studies based on microdata have overlooked the relevance of unemployment insurance benefits in affecting work incentives at the extensive margin. The ranking of countries, however, is almost preserved. The highest average long-term PTRs are registered in Denmark and Finland (both 56 percent), followed by Belgium, Greece, Ireland, Luxembourg and Germany. The lowest values of long-term PTRs instead are observed in Bulgaria, Italy and Lithuania. While short-term PTRs range between 83 and 38 percent, long-term PTRs range between 56 percent and 20 percent.Thus, work incentives increase with the duration in unemployment. This can be explained by the nature of unemployment benefits. The newly unemployed are mostly eligible for unemployment insurance which is limited to a certain period. Once unemployment insurance is exhausted, the unemployed may be eligible for unemployment assistance in a limited number of countries (for instance in Germany, Hungary, Finland, the United Kingdom and Austria). Unemployment assistance is still very often earnings-related but the replacement rate (less generous) and eligibility criteria differ from unemployment insurance. Once the unemployed person has exhausted all kinds of unemployment benefits they would need to rely on the social net of last resort, such as social assistance benefits. Typically, social assistance benefits target low income individuals and households to guarantee a minimum level of income. As such, the level of the benefit is independent of previous earnings but often based on the household structure, the household's means and other income sources. The different nature, purpose and target groups of these benefits lead to differences in short- vs. long-term PTRs. The average difference across countries is 21 percentage points. The largest differences are observed in Belgium (over 44 percentage points), followed by Bulgaria, Czech Republic, Denmark, Germany, Estonia, and Ireland. On the other hand, the smallest 
differences are registered in Ireland and Malta and in the UK. These low values suggest that work incentives in the latter countries are very similar for the short-term and the long-term unemployed.

Long-term PTRs are not only lower than short-term PTRs but also show a greater dispersion. This might result from high heterogeneity in targeting systems for social assistance benefits, as well as from differential effects of the tax-system on the lowest incomes. Further, we notice that in general the median long-term PTR is below the national mean for almost all countries, suggesting a higher concentration of individuals at lower long-term PTR levels.

The third set of columns in Table 1 presents results on METRs. While the PTRs discussed focus on the incentive to actually participate in the labour market, the following sections focus on the incentives faced by workers on the intensive margin of labour supply. METRs measure the strength of the incentive for individuals to slightly increase their earnings either through working more hours or bonus payments and promotion from the current employer or by getting a better paid job.

Countries with higher mean METRs are typically characterised by highly progressive tax systems, such as Belgium, where on average 54 percent of the gross wage increase is lost as a result of higher income taxes, SICs, and lower benefits. The other countries registering high disincentives at the intensive margin are Denmark, Finland, Germany, Luxembourg, Austria, Netherlands, and Ireland, where over 40 percent of the wage increase would be taxed away. Bulgaria (followed by Malta, Estonia, Cyprus and Spain) is the country providing the highest incentive to earn more: an increase in gross wage would be taxed away for less than 22 percent on average ${ }^{5}$.

Fig. 1 Short-term PTRs vs. Long-term PTRs (left) and vs. METRs (right) in 2017. Note: average values shown, the dotted line refers to the EU plus UK average. Source: own calculations using EUROMOD version H1.0+.
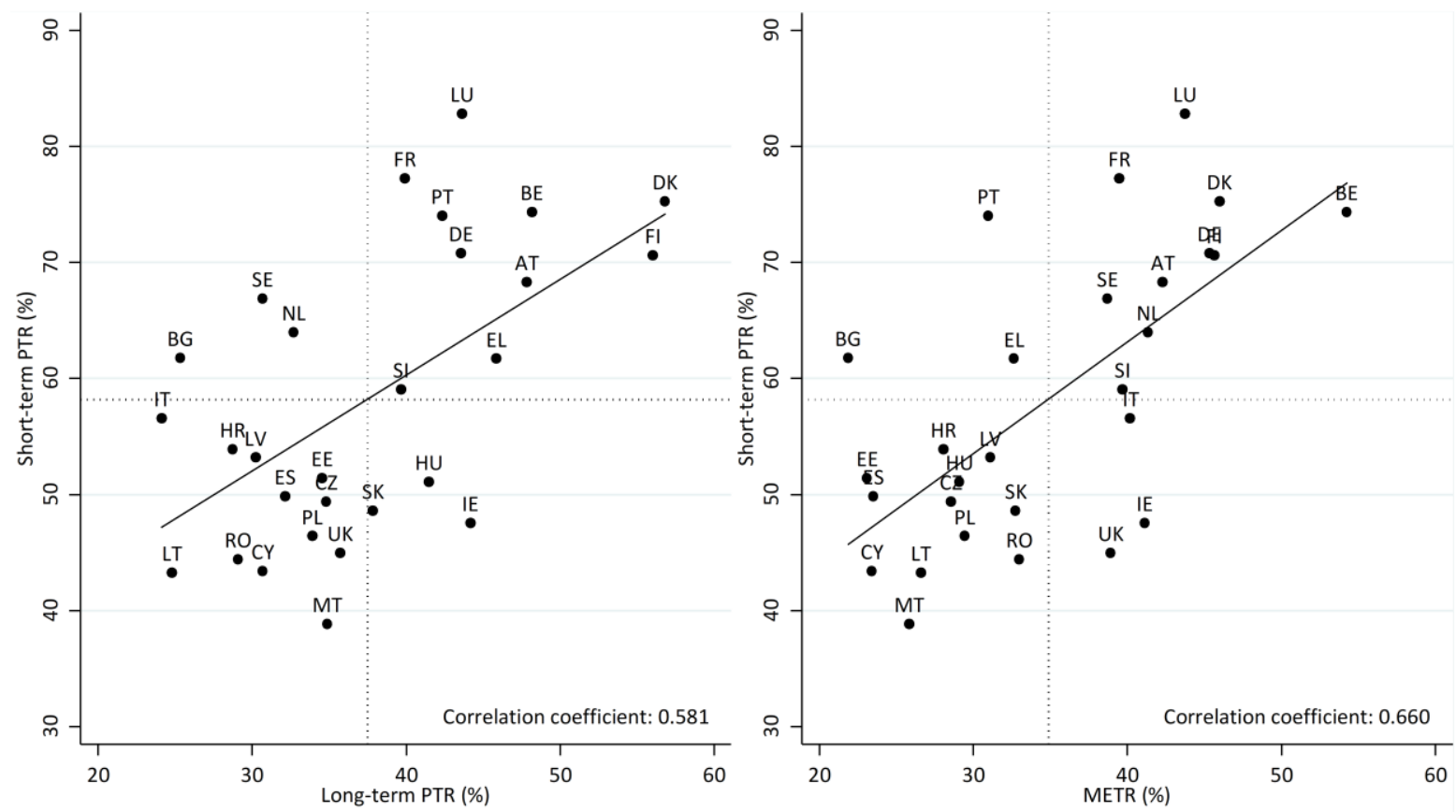

Table 1 also presents results for the 25th and 75th percentile of METRs which are typically quite narrow in countries with a flat-tax system (or a tax-system based on very few tax brackets), such as Hungary, Bulgaria, Czech Republic, Slovakia and Lithuania. In these countries, the distribution of METRs is highly concentrated around the mean. Alternatively, we observe greater variation in METRs in countries like Spain, Cyprus, Croatia, Portugal, Greece, France, and Ireland, mostly due to the greater progressivity in the income tax system.

\footnotetext{
${ }^{5}$ Our calculations include employee social insurance contributions only while including employer social insurance contributions might actually lead to different tax wedges.
} 
Figure 1 provides a summary of average PTRs and METRs in comparison to each other. It offers a useful synthetic characterisation of countries according to the work disincentives implied by their tax/benefits systems. The lefthand side presents short-term PTRs in comparison to long-term PTRs. In the top right quadrant, in fact, we observe countries that present above-average short-term and long-term PTRs. Here we find traditionally generous welfare states such as Nordic countries (Denmark and Finland), and continental welfare models (e.g. Germany, Belgium, France, Luxembourg, Austria). The chart is also useful to identify the countries which are relatively generous in the coverage of the short-term unemployed, but not so much for the long-term unemployed (e.g. the top left quadrant: Sweden, the Netherlands and Bulgaria). On the other hand, countries relatively more generous with the long-term unemployed, such as Ireland, and Hungary, belong to the bottom-right quadrant. A numerous group is finally formed by countries with relatively low short-term and long-term PTRs consisting of the Baltic countries, the UK, and several Central-Eastern European countries (e.g. Poland, Romania, Czech Republic, and Slovenia).

The right-hand side of Figure 1 combines information on short-term PTRs and METRs to characterise countries on the basis of the incentives to work provided by their tax/benefits systems, on both the intensive and extensive margin. The top-right quadrant includes Nordic countries and continental welfare systems, meaning countries presenting low work incentives both at the extensive and at the intensive margin (e.g. through generous benefits and steep tax schedules). Many of these countries provide high levels of support to both short- and long-term unemployed which come at a cost of high taxes and social insurance contributions for those in employment. In the bottom-right quadrant we find Anglo-Saxon economies (UK and Ireland) and Slovenia, characterised by relatively low incentives towards short-term unemployment, but higher than average marginal tax rates, due to tax schedules which impose high marginal tax rates, also at lower incomes. The opposite holds for countries like Portugal, Greece and Bulgaria, which seem to offer lower incentives at the extensive margin, but more so on the intensive margin. Finally, the bottom-left quadrant includes countries showing relatively higher incentives at both extensive and intensive margins, including mostly Eastern European countries, the Baltic countries, and Spain.

It is important to note that the differences in work incentives across countries reflect differences in tax-benefit policies but also differences in population characteristics. In order to have a better idea of the role of population characteristics, we perform a sensitivity analysis, where the population of each country is reweighted to match the population of each of the other 27 countries. This analysis shows how work incentives would look like if all countries were to have similar shares of key population characteristics as those of the country used for the reweighting. ${ }^{6}$ The largest population differences concern skill levels as well as the share of self-employed. Controlling for these characteristics not only changes the population structure but would, to some extent, also change the earnings distribution in the country. However, the earnings distribution and other uncontrolled characteristics such as family structure would still differ across countries.

Nevertheless, work incentive levels remain stable across countries and indicators ( $+/-4$ percentage points) even after the population is reweighted (see Tables 12-14 in the Appendix). There are only a few exceptions: Italy for short-term PTRs, Greece for long-term PTRs as well as Portugal and Hungary for METRs. Overall, the sensitivity analysis suggests that differences in work incentives are mainly driven by the tax-benefit system. This is also line with previous results comparing microdata with hypothetical households, which abstract from differences in population structure and show the pure policy effect (Gasior and Recchia, 2019).

\subsection{Decomposition of PTRs and METRs}

While the previous section showed that countries comprise of different average levels emphasising the general role of different tax-benefit elements, this section sheds light on the country-specific decomposition of the indicators. It discusses the decomposition of mean PTRs (short- and long-term) and METR across countries by main income sources: unemployment benefits, social assistance benefits, family benefits and pensions, and reduced income taxes and social insurance contributions.

\footnotetext{
${ }^{6}$ Reweighted results make use of reweight2 (Browne, 2012) in STATA. We reweight based on the following characteristics: age $(0-9,10-19,20-34,35-49,50-64,65+)$, gender (woman, men), education (restricted to those aged 20-64: maximum lower secondary, (post) secondary, tertiary), labour market status (employed, self-employed, unemployed/inactive, other inactive). A reduced version of this model is applied to selected country combinations.
} 
Starting with short-term PTRs, Figure 2 shows that, on average, unemployment benefits are the most important component of PTRs, followed by social insurance contributions and direct income taxes. However, important differences exist across countries. Countries characterised by generous unemployment insurance systems show PTRs above 70 percent, and, in these countries, unemployment benefits represent the most important component driving short-term PTRs. For instance, Luxembourg is by far the country with the highest contribution of unemployment benefits to total short-term PTRs (over 70 percentage points), followed by Finland, Sweden, France, and Portugal (over 50 percentage points). Luxembourg and Sweden are characterised by high gross replacement rates for short unemployment durations (e.g. around 80 percent of previous wages). In Finland, most employees are covered by generous unemployment insurance in terms of benefits amount and duration, and thus, would receive a relatively high unemployment benefit compared to previous employment income (Jara, Sutherland and Tumino 2016).

Fig. 2 Decomposition of mean short-term PTRs by income source in 2017. Note: countries ranked by mean short-term PTR. See also alternative representation of results in Figure 10 in the Appendix. Source: own calculations using EUROMOD version H1.0

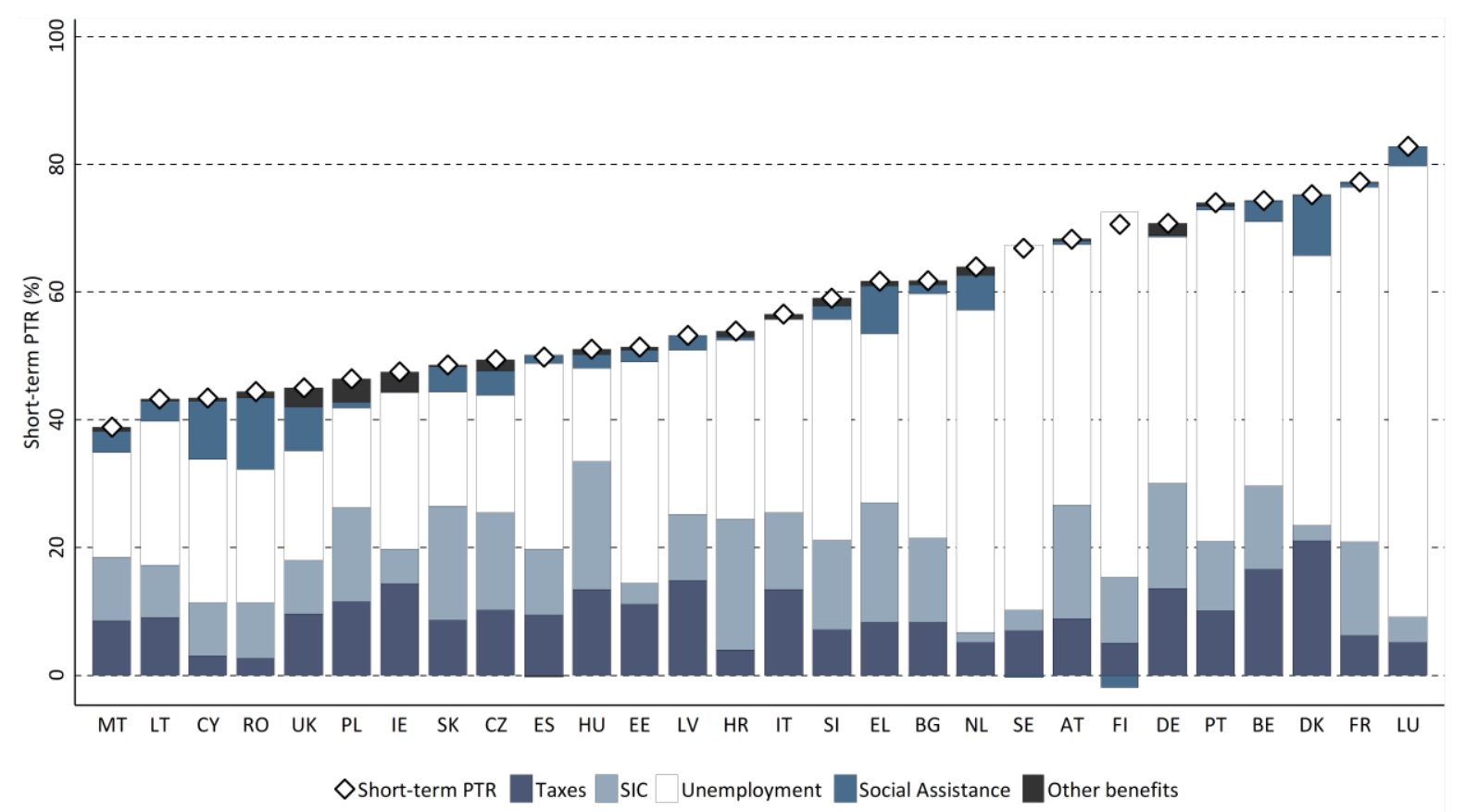

At the other extreme of the distribution, in Slovakia, the UK, Malta, Hungary, and Poland, the contribution of unemployment benefits to short-term PTRs is the lowest in Europe (15 to 17 percentage points). In these cases, the results can be explained by the short duration of unemployment insurance benefits (e.g. only 3 months in Hungary), by low or flat-rate unemployment benefits (e.g. in the UK and Malta), by low caps to maximum unemployment benefits amounts (e.g. in Hungary, Slovakia and Poland), and by low levels of or limitations to unemployment allowances after the expiration of unemployment benefits.

Other benefits, such as social assistance benefits, family benefits and pensions (mostly from other household members) play a comparably minor role. In general, the average contribution of social assistance benefits to total short-term PTRs is 3 percentage points. Countries with higher contributions are Romania, Denmark, Cyprus, Greece and the UK, where the higher importance of social assistance benefits on PTRs can be explained by the presence of guaranteed minimum income schemes that do not rule out eligibility for the short-term unemployed (Greece introduced a new guaranteed minimum income scheme in 2017). The contribution of other benefits is minor and mainly driven by family benefits. In Poland, the UK and Germany, family benefits account for between 4 and 2 percentage points of short-term PTRs, respectively, but in almost all other countries, their contribution falls below 1 percent. 
In some countries, high short-term PTRs are not only the result of unemployment benefits, but are also driven by reduced income taxes and social insurance contributions. This is the case, for instance, in Denmark, Belgium and Germany. All three countries have short-term PTRs above 70 percent and reduced income taxes and social insurance contributions account for up to 30 percentage points of total PTRs. In addition to Denmark and Belgium, the largest incidence of taxes and social insurance contributions to the short-term PTRs is observed in Greece, and, above all, Hungary ( 33 percentage points out of 52 percent total PTR). High contributions of reduced incomes taxes and social insurance contributions to short-term PTRs can also be found in Austria, Slovakia, Poland, Czech Republic, Italy and Latvia (27 to 25 percentage points). The relative importance of reduced income taxes (see Denmark, Belgium, Latvia, Ireland, Germany) vs. reduced social insurance contributions (Greece, Slovakia, Austria, Germany, Slovenia) varies in these countries.

In summary, although we can observe a number of contribution-financed "Bismarkian" systems (e.g. Belgium, Austria and Germany), typically providing a relatively stable safety net in case of unemployment, (see Figari et al. 2011) among the countries with the highest incidence of reduced social insurance contriubitons and income taxes on PTRs, the composition is diverse and cannot be associated to a single typology of welfare-system.

In general, the results show that labour market (dis)incentives seem to be associated with either benefits (e.g. the Netherlands) or taxes/social insurance contributions (e.g. Hungary), but rarely with both in most countries. It is interesting to point out that in Nordic countries and in several other European welfare states, benefits explain over 70 percent of total short-term PTR. While this appears to be in line with the conventional wisdom that benefit dependency is triggered by generous replacement rates (Cappellari and Jenkins 2014; Hansen et al. 2014; Königs 2014; Lalive 2007), we also find that the role of direct income taxes and social insurance contributions cannot be ignored. ${ }^{7}$ In fact, in at least half of the countries, income taxes and social insurance contributions account for at least 40 percent of short-term PTR (over 60 percent in Hungary, and between 52 percent and 57 percent in Poland, Slovakia and Czech Republic). This finding will become more apparent when considering long-term PTRs, as explained in the following paragraphs.

Turning to long-term PTRs, Figure 3 shows that the results of the decomposition change substantially with respect to short-term PTRs. Reduced taxes and social insurance contributions have a larger incidence on long-term PTRs than short-term PTRs, accounting on average for 24 percentage points, out of 36 percent (the average long-term PTR across countries). The combined incidence of taxes and social insurance contributions on long-term PTRs is particularly high in Belgium, Hungary, Denmark, Slovenia, and Germany.

\footnotetext{
${ }^{7}$ Note, however, that we focus on people currently in work whereas people out of work are likely to have lower earnings potential and hence a greater benefit trap. An analysis of short-term PTRs for low earners only, i.e. a group likely to be more similar to those currently out of work, shows that social insurance contributions still contribute to short-term PTRs (12 percent on average) even for low earners while this is less the case for income tax (1 percent on average).
} 
Fig. 3 Decomposition of mean long-term PTRs by income source in 2017. Note: countries ranked by mean long-term PTR. See also alternative representation of results in Figure 11 in the Appendix. Source: own calculations using EUROMOD version H1.0

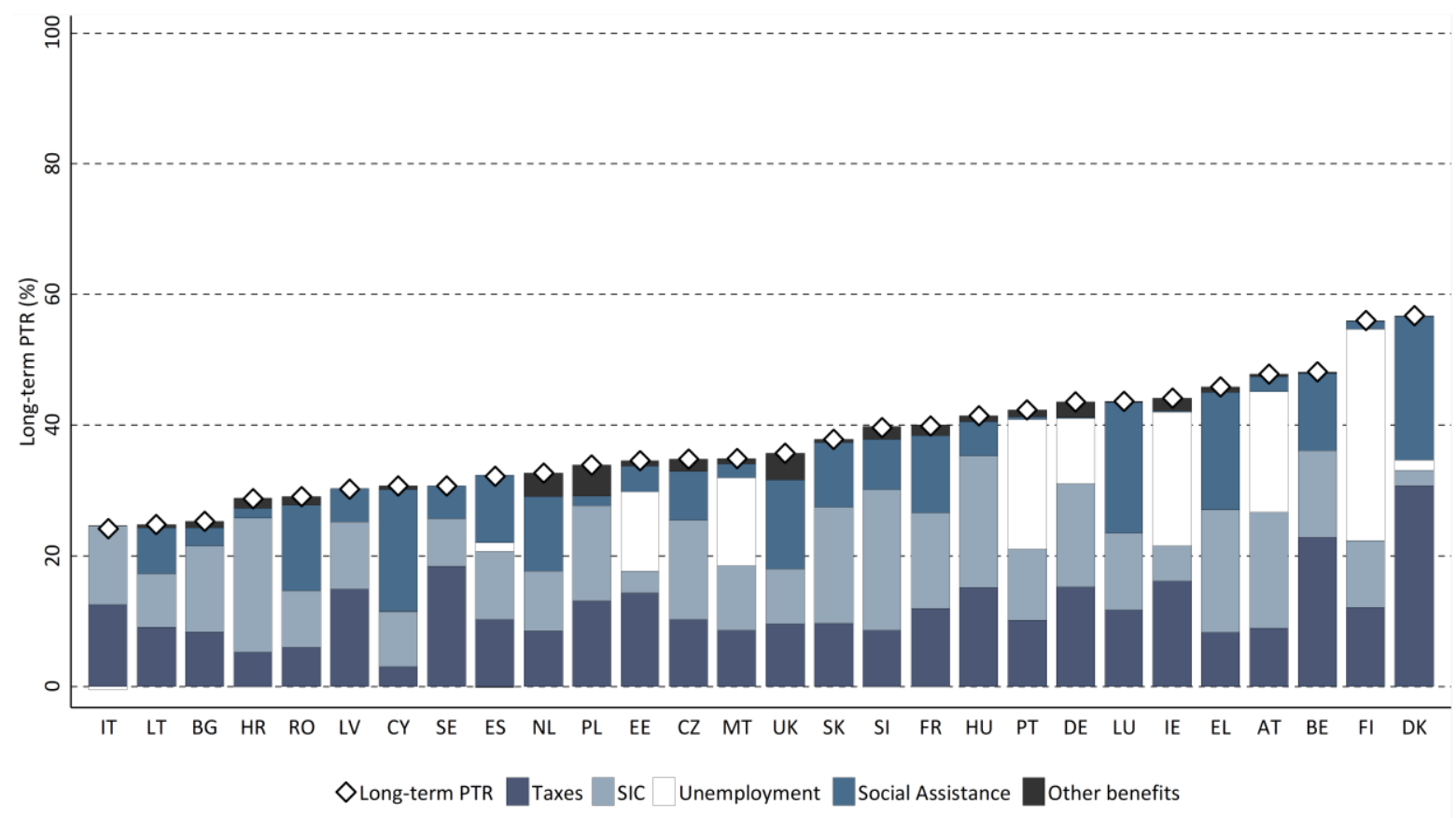

In most countries, unemployment insurance benefits have been exhausted and are replaced by follow-up benefits (e.g. unemployment assistance or social assistance). Comparing the decomposition of short-term PTR and longterm PTR highlights the importance of considering the tax-benefit system as a whole, as different elements contribute to work incentives when unemployment duration matures. In Denmark, the high long-term PTR reflects the generosity of social assistance benefit, which is still able to provide at least half of a household's disposable income after entitlement to unemployment insurance benefits has been exhausted. Fernandez Salgado et al. (2014) highlight the role of a developed social assistance scheme and the danger of falling below the poverty threshold if such a system does not exist. The relatively high value for Greece also likely reflects the introduction of the new guaranteed minimum income scheme. Other countries in which social assistance benefits matter in explaining long-term work incentives are Luxembourg and Cyprus, and to a lesser extent, the UK and Romania. In the case of Bulgaria, instead, the low long-term PTRs relate to the very low level of social assistance benefit available to people exhausting entitlements to unemployment insurance. The same is true for Lithuania. In Italy, the low value probably stems from the fact that the 2017 tax/benefit system does not yet include the new Italian guaranteed minimum income benefit ("Reddito di Inclusione"), introduced in January 2018; in the absence of last-resort safety nets, a substantial share of the long-term unemployed in Italy is left with very low or no incomes.

Unlike Denmark, high long-term PTRs in several countries (e.g. Finland, Austria, Germany, Portugal, Hungary and Slovenia) do not result from particularly generous social assistance benefits, but rather from the effect of reduced taxes and social insurance contributions, and, in some cases (Finland, Austria, Ireland, Germany and Portugal), from generous unemployment benefits for the long-term unemployed. In Finland, for instance, the high long-term PTR is mostly explained by high unemployment benefits, firstly, and secondly by reduced income taxes and social insurance contributions, while social assistance benefits have only a minor influence on long-term PTR. In fact, Finland maintains relatively generous unemployment assistance benefits even in the long-run, once the entitlement to the main unemployment insurance benefits is exhausted: as a result, unemployment benefits still account for 32 percentage points out of 55 (almost 60 percent) of the long-term PTR. Further, in Ireland, high unemployment benefits and reduced income taxes explain most of the long-term PTR (20 and 16 percentage points, respectively). In Germany, long-term PTR can be mostly explained by reduced income taxes and social insurance contributions, and, to a minor extent, by unemployment benefits. Similarly in Portugal, long-term PTR are mostly driven by unemployment benefits, and by reduced taxes and social insurance contributions. 
In Hungary, on the contrary, the components that account the most for high long-term PTR are reduced taxes and social insurance contributions, rather than the generosity of last resort social assistance programmes or benefits for the long-term unemployed. Finally, also in Slovenia, high long-term PTR are mostly due to high social insurance contributions, and, to a minor extent, reduced income taxes. Slovenia also shows the highest contribution of social insurance contributions to total long-term PTR (21 percentage points) in the EU and the UK, followed by Croatia, Hungary, Greece, Slovakia and Austria.

As in the case of short-term PTRs, other benefits only marginally impact on mean long-term PTRs. The countries where family benefits matter the most for long-term PTRs are Poland, the UK, Czech Republic and Slovenia. One possible explanation could be that, in these countries, some family benefits are designed as in-work benefits or tax credit and allowances, and therefore are lost when beneficiaries move from employment into long-term unemployment. Another possible explanation could be that these benefits entail last resort programmes specifically designed for households with children, where beneficiaries are long-term unemployed. The relatively larger effect found in Poland, could be explained by the generous child benefit "Family 500+", launched by the government in 2016. In the remaining countries, the contribution of family benefits to long-term PTRs falls below 2 percent.

Overall, social assistance and other benefits (mainly driven by family benefits) represent the most important component of long-term PTRs in only a minority of countries (Cyprus, Finland and Ireland). In general, reduced taxes and social insurance contribution are actually more important determinants of long-term PTRs and in half of the countries they account for at least 70 percent of the total PTR.

The role of taxes and social insurance contributions is even more pronounced when focusing on METRs (Figure 4). Our decomposition exercise shows the relative incidence of taxes, social insurance contributions and (loss of) benefits to the mean METR. Higher taxes associated with higher earnings represent the most important component of mean METRs. Denmark registers by far the highest contribution of direct income taxes to average METR (44 percentage points out of 46 METR), followed by Belgium, Finland, Sweden, Ireland, Italy and Germany. On the contrary, in countries characterised by lower progressivity, such as Lithuania, Slovakia, Hungary, and Bulgaria, the contribution of taxes to the mean METR remains low, only between 15 and 8 percentage points.

In Hungary, increases in social insurance contributions due to higher earnings explain over 19 percentage points of average METR. Other countries where high social insurance contributions explain an important component of METRs are: Slovenia, Croatia, Slovakia, Austria, Greece, Belgium and Germany.

Finally, loss of benefits associated with higher earnings seem to matter in the UK ( 9 percentage points), followed by France, Luxembourg, Cyprus, Ireland, the Netherlands, Romania and Slovenia. In the UK, the loss of benefits is associated with a reduction in means-tested benefits (in-work benefits and housing benefits), as income from labour increases. Like in many countries, low income earners are eligible for these benefits which are however lost after earnings increase by $3 \%$. 
Fig. 4 Decomposition of mean METR by income source in 2017. Note: countries ranked by mean METR. See also alternative representation of results in Figure 12 in the Appendix. Source: own calculations using EUROMOD version $\mathrm{H} 1.0$

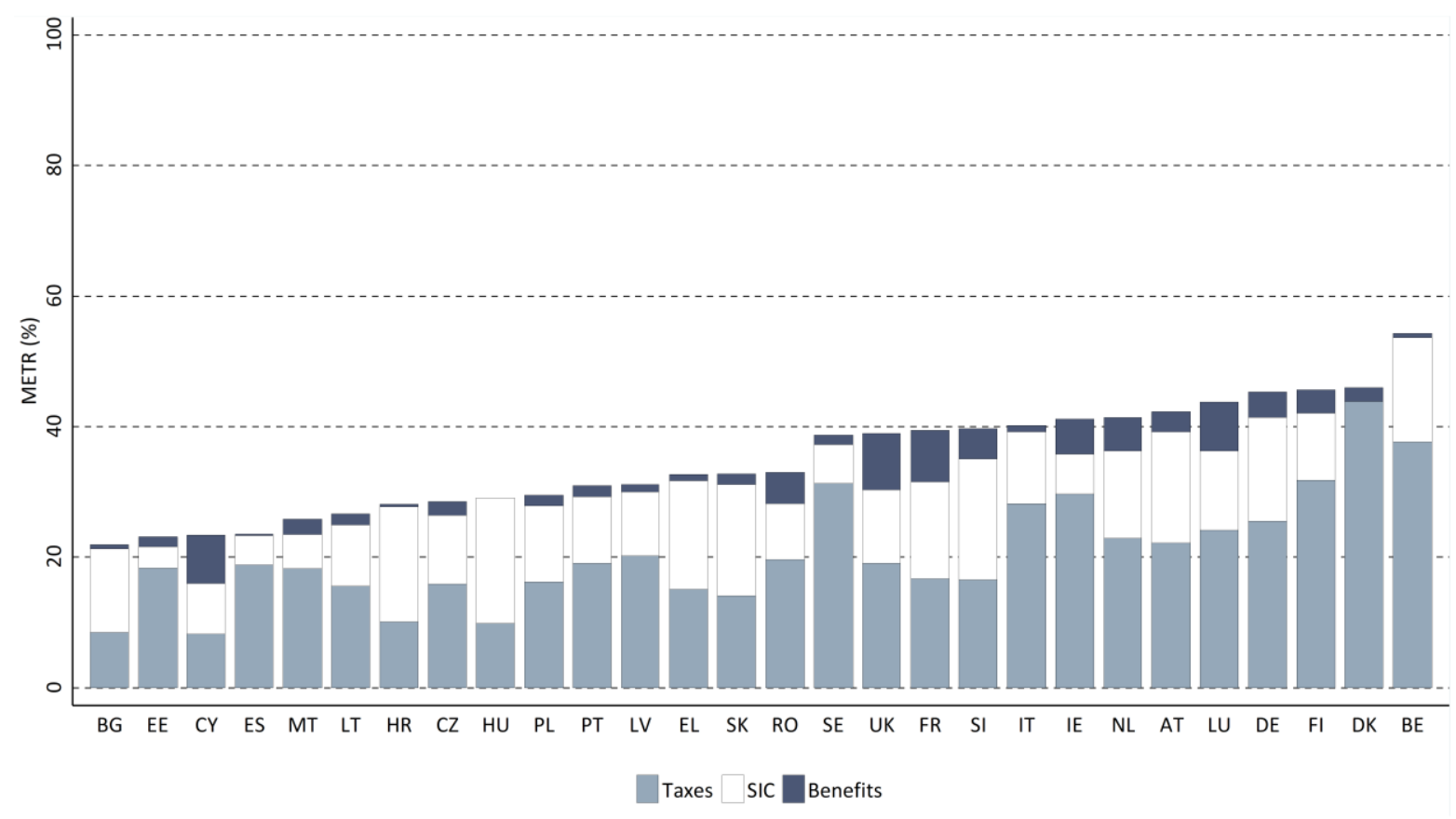

Overall, these results firstly suggest that various tax-benefit elements contribute differently to work incentives at the intensive vs. the extensive margin and secondly, may also be different for work incentives at the intensive margin when unemployment duration matures. It is furthermore important to note that while the role of taxes and social insurance contributions is obvious in the case of METRs, it also needs to be taken into account for PTRs.

\subsection{Heterogeneity across population subgroups}

An advantage of using representative data for the analysis of work incentives is that it allows us to compare indicators across different population subgroups. Tables 9-11 in the Appendix compare mean PTRs (short- and long-term) and METR for a wide range of sub-population groups. The following subsection discusses the most important differences between sub-population groups for each of the indicators.

In terms of short-term PTRs, marked differences are observed between employees and the self-employed, across earnings quintiles, people at-risk-of-poverty, those at high risk of unemployment, and, to a minor extent, between age groups and type of earners (main vs. secondary). On the other hand, differences between men and women are very small across countries. This is partly explained by the nature of the indicator which captures changes in household incomes and the role of the tax-benefit system rather than the change in individual earnings.

In general, employees face higher PTRs than the self-employed, since the latter are not always eligible for unemployment insurance benefits, or are subject to lower compulsory social insurance contribution rates. However, in a number of countries, the reverse is true: for example, in Hungary, the PTR for self-employed exceeds employees' by 39 percentage points because the self-employed are eligible for unemployment insurance benefits and face high social insurance contributions.

Short-term PTRs are much higher for workers in the bottom vs. the top quintile of the earnings distribution. These differences can be explained by the existence of lower limits in unemployment insurance schemes (minimum payments amount for people satisfying eligibility conditions) and by access to out of work benefits, such as minimum income schemes (e.g. as in Greece) and other social assistance benefits. While high PTRs for the lowpaid reflect the degree of income protection provided by the tax-benefit system, overly high PTRs at the bottom 
of the earnings distribution can discourage labour market participation among the poor, creating benefit dependence and unemployment traps. An alternative interpretation is that low earners in many countries can be eligible for the guaranteed minimum income scheme while working (see Appendix B), leading to similar income levels in and out of employment. In some countries, low earners face a higher incentive to work than top earners, due to important tax allowances and family benefits in the upper part of the earnings distribution, as in the case of Italy (where the gap between top and bottom earners' PTR reaches 21 percentage points), Netherlands, Latvia, Germany, Romania and Slovenia. Interestingly, the level of work incentives for low paid workers is not necessarily reflected in PTRs for people facing high risk of poverty or unemployment. Short-term PTRs of the working poor ${ }^{8}$ are significantly higher compared to the overall sample and low earners in the majority of countries indicating a potential poverty-trap if they lose their job. On the other hand, high unemployment-risk workers have higher incentives to be employed than the overall population in the majority of countries. Their PTRs are considerably lower in two thirds of the countries. This might, however, be related to the difficulty of estimating the risk of unemployment based on cross sectional data.

Differences in PTRs by skill, working hours and age levels are more difficult to interpret since they are more likely to be mixed up with differences associated with earnings: for instance, older workers might exhibit higher PTRs because they enjoy higher earnings, and therefore fall into higher tax brackets. The evidence actually shows that older workers face higher PTRs than younger workers in almost all countries (the difference reaching 20 percentage points. in Slovenia and 16 in the Netherlands), with the exception of Malta and Greece. As far as skills groups are concerned, low-skilled workers tend to show higher PTRs than medium- and high-skilled workers in almost all countries, although the variation of PTRs across skills groups is relatively small. The evidence for parttime workers is mixed. We observe larger disincentives for part-timers in several countries (e.g. Greece and Hungary) while in others (e.g. Italy, Romania, Latvia and Germany), part-time workers seem to face lower disincentives to work than full-time workers. This is mainly driven by lower social security contributions paid by this group. High PTRs for part-timers can be associated with eligibility for social assistance benefits given the usually low level of earnings received by this group. Finally, in general, main earners exhibit higher PTRs, which is related to the larger contribution of unemployment insurance benefits given that the latter are proportional to previous earnings in most countries.

As far as long-term PTRs are concerned, we notice that the variation across sub-groups tends to decrease compared to short-term PTRs, and in some cases the results point in different directions. In contrast with short-term PTRs, in general the self-employed show higher long-term PTRs than employees. The difference between the short- and long-term scenarios reflects the role of unemployment insurance schemes in work incentives. During the first year of unemployment (short-term) employees face higher PTRs than the self-employed because in general the latter group is not covered by unemployment insurance. Once unemployment insurance has been exhausted (long-term) the self-employed exhibit higher PTRs reflecting a stronger contribution of social assistance to PTRs for this group. The gap between main and secondary earner PTRs tends to increase in the long-term. The main earners' higher long-term PTRs are driven by two factors. On the one hand, the decrease in household disposable income is smaller in the case of unemployment of secondary earners compared to main earners meaning that the contribution of social assistance (and other means-tested benefits) to PTR would be smaller for secondary earners. On the other hand, taxes and social insurance contributions have a stronger incidence on long-term PTRs compared to benefits and their incidence would be larger for individuals with higher earnings (main earners compared to secondary earners). The results are in line with studies by Immervoll, Kleven, Kreiner and Verdelin (2011) and more recently Bartels and Shupe (2018) and further highlighted in the results for the working poor. Their long-term PTRs are mostly in the same direction as for low-paid workers and considerably higher than for the overall sample. This shows that the potential of a poverty trap implicit in many tax-benefit system increases with the duration of unemployment. This is also supported by higher work disincentives for people with high risk of unemployment. Differing from short-term PTRs, long-term PTRs for this population subgroup are generally higher than for the overall sample.

\footnotetext{
${ }^{8}$ Working poor in this paper refers to someone in employment (i.e. with positive earnings) living in a poor household with less than $60 \%$ of the national median equivalised disposable household income.
} 
In the case of METRs, the largest differences are observed between earning quintiles, people at-risk-of-poverty as well part-time vs. full-time workers. Earners in the top quintile of the distribution face higher METRs than those at the bottom in almost all countries, and the difference can reach more than 30 percentage points as in Italy, Greece, Ireland and Spain. Higher METRs at the top of the earnings distribution mainly reflect the progressivity of income taxes, with high earners paying a higher proportion of the additional earnings in taxes. Results furthermore show almost no difference between in METRs of employees and the self-employed, as well as between main and secondary earners, with a few exceptions.

\subsection{Low work incentives at the extensive and intensive margin}

While different population subgroups face different levels of work incentives in general, it is also useful to have a portrait of those facing low work incentives specifically. High levels of PTRs and METRs are an indicator of low incentives to work or to increase labour supply. In this section, we provide a cross-country comparison of the share and the characteristics of individuals facing low work incentives at the extensive and intensive margin (see Table 15-17 in the Appendix for the underlying data).

In the literature, there is no consensus yet as for which level of PTR or METR should be regarded high enough to identify people as facing low work incentives. Two different approaches could be considered. On the one hand, a relative threshold could be defined for each country based, for instance, on the median value of each indicator in each country. This would allow taking into account the very different distributions of work incentive indicators across countries. However, from a cross-country comparative perspective, the relative threshold might be too low to characterise some individuals as facing low work incentives in certain countries. The different distributions of work incentives across countries and indicators furthermore lead to a wide variation of relative thresholds, which render cross-country comparison meaningless. Relative short-term PTR thresholds range from 37 percent in Malta to 105 percent in Luxembourg, relative long-term PTR thresholds vary between 25 percent in Cyprus up to 62 percent in Finland, and MTR thresholds range from 15 percent in Cyprus to 66 percent in Belgium. In this sense, the definition of an absolute threshold seems more appropriate for a comparable characterisation of groups facing low incentives to work even if it neglects the variation in the dispersion of work incentives across countries. Given our focus on cross-country comparison, in this section we discuss the results based on an absolute threshold, but we provide the results based on relative thresholds in the Appendix (see Table 18-20). We follow an approach taken by Jara and Tumino (2013) who define the threshold as the average plus one standard deviation of the mean across all countries. In the case of short-term PTRs, the absolute threshold corresponds to a value of PTR equal to 75 percent. For both long-term PTRs and METRs, the value of the threshold is 50 percent. Both the share of those facing low work incentives and the underlying sample size are sensitive to the chosen threshold given that relative and absolute thresholds can be quite different from each other. Nevertheless, the portraits and patterns described in the following paragraphs remain essentially unaffected by the choice of threshold with the exception of the share of people at risk of poverty which is more sensitive to the applied threshold in selected countries.

The share of workers facing high short-term PTRs varies widely across countries. In Latvia, Croatia, Czech Republic and Slovakia, less than 5 percent face a high disincentive to work, while the share is as high as 81 percent in France and 84 percent in Luxembourg. In more than half of the countries, the majority of people with low work incentives are women, particularly so in Italy and Ireland. Young workers (below 30 years old) are typically the least affected by low work incentives (with the exception of Malta). This might be related to age restrictions for the entitlement of certain benefits or to the fact that young workers may not fulfil eligibility conditions based on work history, for instance, for unemployment insurance benefits. In terms of skill groups, the majority of individuals facing high short-term PTRs are medium skilled, while low-skilled represent the largest share only in a small number of countries (Spain, Malta, Portugal, Romania and the UK). Those facing high disincentives are furthermore less likely to be self-employed (given that not all countries provide unemployment benefits for the self-employed) and more likely to be main earners (with the exception of Czech Republic, Italy, Malta and Poland). A very high share (more than 60 percent) are part-timers in Ireland, followed by Greece, Spain, Austria and the UK (with more than 40 percent). In terms of earning quintile groups, the largest share is made of individuals with low earnings in most countries, which might be related to the existence of lower limits for unemployment insurance benefits or social assistance (e.g. minimum payments amounts in both cases for those 
satisfying minimum requirements). Especially in countries with very high shares of low paid workers among those facing low PTRs, people are also very likely to be at risk of poverty (with almost 100 percent in Latvia). The picture is rather different in Germany and the Netherlands, where individuals at the top of the earnings distribution are more likely to be among those with high short-term PTRs.

The share of those with a high risk of unemployment is comparably low in many countries but quite pronounced in Latvia and Lithuania. Factors leading to low work incentives are not necessarily correlated with higher unemployment risks. Youth unemployment, for example, is higher than for the average population in many European countries (O'Reilly et. al. 2015) but the share of young workers among the low work incentive risk group is comparably low. In a similar vein, low education is a well-studied factor of lower unemployment risk (Riddell and Song 2011) which is only reflected in a small number of countries. This in turn also highlights that those at highest risk of unemployment are not necessarily those with the highest benefit entitlements in case of unemployment.

There is also significant variation in the share of individuals affected by high long-term PTRs: Bulgaria and Italy have the lowest share of the working population affected by high long-term PTR (below 3 percent), while Finland, Denmark and Belgium, on the other end of the spectrum, show the highest incidence of high long-term work disincentives (affecting over 40 percent of workers). The portrait of those facing low long-term work incentives is similar to short-term PTRs in terms of individuals being more likely to be employees, middle-aged, main earners and low earners. In particular, countries with very high shares of low earners also comprise of high shares of people at-risk-of-poverty faced with low work incentives (Bulgaria, Romania and Lithuania). About one third are furthermore at high risk of unemployment in Bulgaria, Lithuania as well as the Netherlands. Contrary to the case of short-term PTRs, men are more likely than women to face high long-term PTRs. This is also confirmed in results for part-time workers who are mostly women and constitute only a small group of those faced with low long-term PTRs in most countries.

Finally, the share of people facing low work incentives at the intensive margin varies across countries but to a lesser extent if compared to the variation in the incentives at the extensive margin (except for Belgium). The share of workers facing low work incentives at the intensive margins (METR above 50 percent) ranges, in fact, from 0.5 percent in Spain to 34 percent in Sweden, and reaches 81 percent in Belgium, which remains an outlier. The portrait of individuals facing low incentives at the intensive margin is quite similar to results for long-term PTRs. However, results by gender exhibit greater variation with more countries showing higher shares of women facing high METR (especially in the Czech Republic and Cyprus). The same result holds across earning quintiles, where high earners are the largest group facing high METR, especially in Greece and the Scandinavian countries. The high share of low earners in Baltic countries as well as Bulgaria and Romania is also reflected in a high share of people at risk of poverty. Except for Estonia and Romania, these countries plus the Czech Republic also present a high share of people with high risk of unemployment (above 40 percent). In addition, differences between employees and self-employed are more pronounced in most of the countries. In Lithuania, over 50 percent of parttime workers face METRs above 50 percent, while in the rest of the countries, this percentage is much smaller, and particularly low (around 4 percent) in Italy and Hungary.

Probit results (provided in Table 21 in the Appendix) show the extent to which differences by characteristics are actually correlated with differences in the composition of other factors. Overall, earnings levels and being employed as opposed to self-employed as well as being at risk of poverty seem to be the strongest explanatory factors for low work incentives. All other workers' characteristics are significant though the magnitude of the effect seems smaller. In particular, the effect of gender is comparably small after taking differences in age, skilllevel, earnings and employment characteristics into account (especially in the case of METRs).

\subsection{Evolution of work incentives over time}

This final section analyses the evolution of work incentives between 2008 and 2017. We use the same EUROMOD input datasets for both policy years in order to control for changes in the population and employment composition. Thus, the discussed changes in work incentives capture the effect of policy changes (or to some extent also the result of no policy changes, if for example earning levels increase higher than minimum levels of unemployment 
insurance benefits). In Figure 5, the left-hand side chart shows the change in the work incentives at the extensive and intensive margin, while the right hand-side shows the share of workers affected by low work incentives in the two periods.

Work incentives at the extensive and intensive margin have remained rather stable in most countries. This is especially the case for METRs and long-term PTRs whereas larger changes are observed for short-term PTRs. The countries with the largest increases in short-term PTRs are Portugal, Belgium, Greece, Bulgaria and Estonia. The country with the largest decrease in short-term PTRs is Hungary followed by Romania. In Belgium, Portugal and Bulgaria, policy changes have also resulted in a larger group of people facing high short-term work disincentives. The same is true for Finland and Greece in terms of long-term PTRs.

The drop by more than 10 percentage points in short-term PTRs in Hungary can be explained by changes to the unemployment insurance benefit. In fact, the maximum duration of unemployment insurance benefits decreased from 9 to 3 months, and the maximum benefit amount changed from 120 percent of the minimum wage to the level of the minimum wage. Given that the benefit duration was below 12 months in both years, these changes had no effect on long-term PTRs. The changes in Romania are also mostly driven by the unemployment insurance scheme. However, contrary to Hungary, these changes are not the result of actual policy changes, but rather the consequence of the lack of uprate in the flat rate amount of the unemployment insurance benefit.

Increases in work incentives at the extensive margin are also mostly attributed to changes in unemployment insurance benefits due to increases in the duration of the unemployment insurance benefit or the above wage increase of minimum and maximum benefit levels. Bulgaria increased the qualifying period which potentially increases the number of people eligible for the benefit in case of unemployment. Given that the unemployment insurance benefit is paid for less than a year in most countries, these changes had no effect on long-term PTRs.

In Portugal, the main policy changes over time consisted of a reduction of both the qualifying period for unemployment insurance benefits and the benefit amounts. The group of unemployed people eligible for unemployment benefits was expanded to include people with less work experience, and, as a consequence, the group of people eligible for receiving unemployment benefits for a full year has increased. All together, these changes led to a substantial increase in work disincentives by almost 20 percentage points. At the same time, changes in unemployment assistance seem to have led to a decrease in long-term work incentives over time. Nevertheless, Portugal is still among the countries with the highest long-term PTR.

Changes in tax and social insurance contributions have impacted changes in work incentives to some extent but have often been counter-balanced by other policy changes. In Estonia, changes in the tax system leading to higher disincentives have been balanced out by changes to the social insurance contributions. In Belgium, the increase in short-term PTRs would have been higher but was to some extent offset by changes to the tax system.

Changes to various tax-benefit elements contributed to the increase in short-term PTR in Greece. The most important contribution to the increase of both short- and long-term PTRs was the introduction of the guaranteed minimum income scheme in 2017, a reform that substantially improved the safety-net of people in unemployment or unable to work. Despite the increase in long-term PTR, the share of workers exposed to high long-term PTR in Greece (around 30 percent), remains below those of countries with more generous social assistance systems for the long-term unemployed (e.g. Austria, Belgium, Denmark, Finland). In Finland, on the other hand, changes towards a more generous social assistance scheme substantially increased the long-term PTR, crowning Finland as the country with the second highest long-term PTR.

Fewer changes have taken place for work incentives at the intensive margin. The exceptions are Denmark and Hungary with decreases in METRs as well as Greece and Cyprus with increases. At the same time, the share with high METRs has changed in many countries with substantial decreases in Hungary - due to the change in tax system - but also in Germany. Increases are especially apparent in Finland and Ireland. 
Fig. 5 Changes in work incentives and share with high work disincentives, 2008 vs. 2017. Source: own calculations using EUROMOD version H1.0
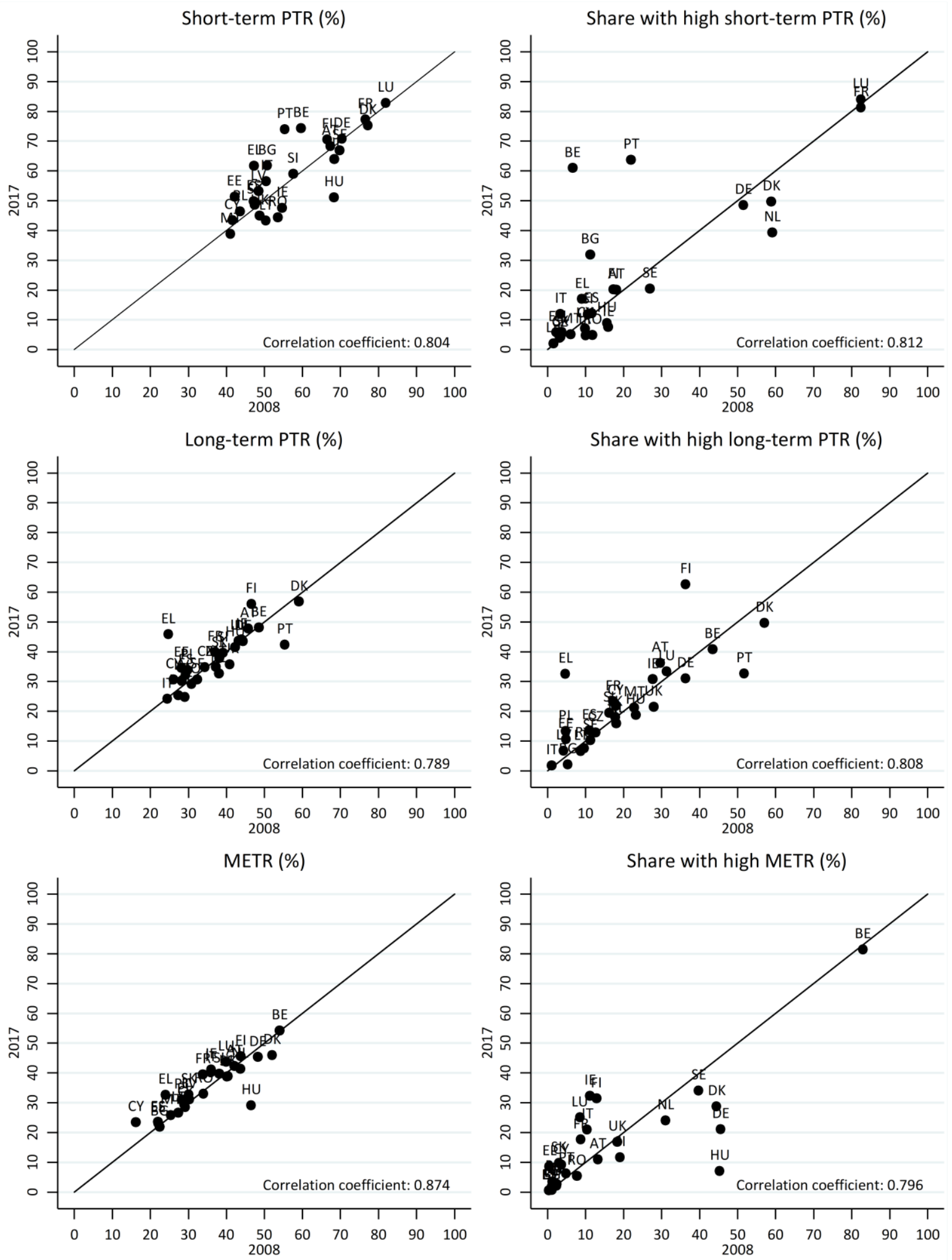

The substantial changes in Hungary are largely based on the shift to a flat-tax system. In Denmark, changes are also based on changes of the income tax system and more specifically on the abolishment of the medium tax bracket, an increase of the earned income tax and a reduction in several other taxes. Nevertheless, Denmark 
remains one of the European countries with the highest METRs. Changes to the Greek tax and social insurance contribution system have increased disincentives not only at the extensive margin but also the intensive margin. Contrary to changes in the other three countries, changes in METRs for Cyprus can mostly be explained by changes in benefits. The previously universal child benefit was turned into a means-tested benefit which results in a loss of the benefit when parent's earnings increase.

Work incentives at the extensive and intensive margin have remained rather stable in most countries. This is especially the case for METRs and long-term PTRs while larger changes have taken place in terms of short-term PTRs.

\section{Conclusions}

This paper presents a cross-country comparison of work incentives at the extensive and intensive margin of labour supply in the EU and the UK. Our analysis makes use of the European tax-benefit model EUROMOD and representative household microdata to estimate short- and long-term participation tax rates (PTRs), and marginal effective tax rates (METRs) in 2017 for individuals currently in work. We show that the design of tax-benefit systems plays an important role in the level and distribution of work incentives and that the role of specific elements differs by country and indicator. The use of microdata allows us to characterise the mean level and distribution of work incentives at the population level and to identify groups facing low work incentives.

Our analysis provides a number of interesting findings. First, there is a large variation in the distribution of work incentives, at the population level, across countries, highlighting the importance of using representative microdata in the analysis. Cross-country differences in the distribution of work incentives reflect, on the one hand, differences in the design of tax-benefit systems and, on the other hand, differences in the composition of the labour market across countries. Our results suggests that differences in work incentives are mainly driven by the design of tax-benefit policies. Second, our comparison of short- and long-term PTRs highlights the important contribution of unemployment insurance benefits to work incentives at the extensive margin, with short-term PTRs being on average 20 percentage points larger than long-term PTRs. Third, workers at the bottom of the earnings distribution face the highest short- and long-term PTRs, which might be related to the presence of lower limits for unemployment insurance benefits (short-term) or social assistance (long-term). At the intensive margin, the highest METRs are observed for high earners, which is most likely related to the progressivity of direct taxes in most countries. Finally, work incentives have remained quite stable over the last 10 years in most countries which can be attributed to a certain path-dependency of social policy.

A closer look at the composition of work incentives across European countries has also highlighted relevant implications for the literature on benefit dependency on the one hand, and for policy design on the other. For instance, given that the benefit component of the short-term PTR is relatively low in countries like Slovakia, UK, Malta, Hungary and Poland, compared to the taxes and social insurance contributions component, it is unlikely that only addressing issues related to benefit levels would have a major impact on short-term work incentives. In fact, the literature on benefit dependency typically focuses on the implications of last-resort benefits levels and duration on the probability of leaving welfare (Cappellari and Jenkins 2014; Hansen et al. 2014; Königs 2014; Lalive 2007), while the potentially sizeable role of reduced taxes and social insurance contributions is typically neglected. The results presented could explain low incentives to work in countries where the level of social assistance benefits is quite low, but the reduction of income taxes and social insurance contribution following the exit from formal employment is more substantial (e.g. Bulgaria). These findings also have implications for countries where social protection benefits are subject to fiscal consolidation measures or spending reviews, given their potential disincentive effects on labour market participation. For this purpose, it would be important to quantitatively assess whether social assistance benefits are actually the main factor driving long-term PTRs. If, on the other hand, reduced income taxes and social insurance contributions appear as the main determinants of long-term PTRs, then policy measures aiming at reducing labour market disincentives should probably be more geared towards alleviating the tax burden on households at higher risk of falling into social assistance (e.g. lowincome households), especially in countries with high informality rates. 
A couple of points related to our analysis deserve particular attention. First, our analysis focuses on the financial incentives inherent in the design of tax-benefit policies. However, individuals' labour supply incentives and choices are also affected by other factors such as the demand side of the labour market. In particular, certain population subgroups might be constrained in the labour market (e.g. low skilled workers) and might, for instance, be unable to work more despite having low financial disincentives to do so (low METRs). Evidence from the literature on job polarisation has, for instance, shown that certain categories of jobs tend to disappear, meaning that certain workers will be constrained in terms of job opportunities (Goos and Salomons 2009; OECD 2015). Labour market regulations might also imply that employers might choose to reduce their risk of hiring certain types of workers. Additionally, the increase in non-standard forms of employment, such as self-employment, might in some cases be the result of inability to find suitable jobs as employees. Finally, other individual constraints such as caring responsibilities or health-related issues would also influence labour supply choices. Our indicators capture differences in work incentives across these groups due to the design of tax-benefit policies (e.g. self-employed not entitled to unemployment insurance) but they do not capture the possibility of individuals being constrained from entering employment. The integration of labour demand within labour supply models accounting for the role of tax-benefit systems remains an area to be further explored and represents an interesting direction for future research.

Second, it is important to note that, at the extensive margin, PTRs not only provide information about work incentives to give up work but also capture the degree of social protection provided by the tax-benefit system in the event of unemployment. As such, the role of the generosity and duration of out-of-work benefits should be considered not only from the perspective of work incentives but also from that of the provision of adequate social support to prevent people from falling into poverty. More generous and longer out-of-work benefits could, for instance, serve as mechanisms for people to find a better job match upon re-entry to the labour market.

Providing a comparative and comprehensive analysis of work incentives across EU countries and the UK based on representative household data is a useful exercise, as it highlights the important differences in the distribution of work incentives associated with differences in tax-benefit systems. The characterisation of population subgroups facing low work incentives, provided in our analysis, can be considered a useful first step to discuss potential reforms to make work pay. From a technical point of view, a comparative analysis further provides a starting point to discuss what the most appropriate definition of low work incentive would be (i.e. setting a threshold, whether relative or absolute). Finally, the availability of work incentive indicators for a wide range of countries based on microdata would allow future work (re)assessing the relationship between the design of taxbenefit systems and labour market outcomes, such as employment and unemployment rates, and female labour force participation, among others.

\section{References}

Adam, S., Brewer, M., and Shephard, A. (2006). "The poverty trade-off: work incentives and income redistribution in Britain", Bristol: The Policy Press.

Bartels, C., and Pestel, N. (2016). "Short- and long-term participation tax rates and their impact on labor supply". International Tax and Public Finance, DOI 10.1007/s10797-016-9400-9.

Bartels, C., and Shupe, C. (2018). "Drivers of Participation Elasticities across Europe: Gender or Earner Role within the Household?". IZA Discussion-Paper No. 11359.

Browne, J. (2012). Reweight2: Stata command to reweight data to user-defined control totals

Cappellari, L., and Jenkins, S. P. (2014), "The Dynamics of Social Assistance Benefit Receipt in Britain", In Carcillo, S., Immervoll, H., Jenkins, S. P., Königs, S., and Tatsiramos, K., editors, Research in Labor Economics: "Safety Nets and Benefit Dependence", Vol. 39, 41-79. Emerald Group Publishing Limited.

Collado, D., Cantillon, B., Van den Bosch, K., Goedemé, T., and Vandelannoote, D. (2019). "The end of the cheap talk about poverty reduction: the cost of closing the poverty gap while maintaining work incentives", In Cantillon, B., Goedemé, T., and Hills, J., editors, Decent Incomes for All: Improving Policies in Europe, Oxford Scholarship Oline, DOI: 10.1093/oso/9780190849696.001.0001.

Decoster, A., Perelman, S., Vandelannoote, D., Vanheukelom, T., and Verbist, G. (2015). "A bird's eye view on 20 years of tax-benefit reforms in Belgium", EUROMOD Working Paper, EM 10/15.

Eurofound (2017). In-work poverty in the EU. Luxembourg, Publications Office of the European Union. 
Fernandez Salgado M., Figari, F., Sutherland, H., and Tumino, A. (2014). "Welfare compensation for unemployment in the Great Recession". Review of Income and Wealth. DOI: 10.1111/roiw.12035.

Figari, F., and Matsaganis, M. (2016). "Making work pay: A conceptual paper". Social Situation Monitor, Research Note 3/2016.

Figari, F., Salvatori, A. \& Sutherland, H. (2011). "Economic downturn and stress testing European welfare systems". In H. Immervoll, A. Peichl, \& K. Tatsiramos, eds. Who Loses in the Downturn? Economic Crisis, Employment and Income Distribution. Emerald Group Publishing Limited, Research in Labor Economics 32, 257-286.

Gasior, Katrin, and Pasquale Recchia. 2019. "The Use of Hypothetical Household Data for Policy Learning - Comparative Tax-Benefit Indicators Using EUROMOD HHoT.” Journal of Comparative Policy Analysis: Research and Practice. (see Supplemental Material).

Goos, M. and A. Salomons (2009). "The polarization of the European labor market." American Economic Review 99(2): 5963.

Hansen, J., Lofstrom, M., Liu, X., and Zhang, X.. (2014), "State Dependence in Social Assistance Receipt in Canada", In Carcillo, S., Immervoll, H., Jenkins, S. P., Königs, S., and Tatsiramos, K., editors, Research in Labor Economics: "Safety Nets and Benefit Dependence", Vol. 39, 81-105, Emerald Group Publishing Limited.

Immervoll, H. (2004). "Average and marginal effective tax rates facing workers in the EU. A micro-level analysis of levels, distributions and driving factors", OECD Social, Employment and Migration Working Paper No. 19, OECD: Paris.

Immervoll, H., Kleven, H., Kreiner, C., \& Saez, E. (2007). "Welfare reform in European countries: A microsimulation analysis". The Economic Journal, 117, 1-44.

Immervoll, H., Kleven, H., Kreiner, C. and Verdelin, N. (2011). "Optimal tax and transfer programs for couples with extensive labor supply responses", Journal of Public Economics, 95: 1485-1500.

Jara, H.X., Sutherland, H. and Tumino, A. (2016) "The role of an EMU unemployment insurance scheme on income protection in case of unemployment." EUROMOD Working Paper Series EM11/16.

Jara, H. X. and Tumino, A. (2013) "Tax-benefit systems, income distribution and work incentives in the European Union". International Journal of Microsimulation, 6(1), 27-62.

Königs, S. (2014), State Dependence in Social Assistance Benefit Receipt in Germany before and after the Hartz Reforms, In Carcillo, S., Immervoll, H., Jenkins, S. P., Königs, S., and Tatsiramos, K., editors, Research in Labor Economics: "Safety Nets and Benefit Dependence", Vol. 39, Emerald Group Publishing Limited, pp. 107-150.

Lalive, Rafael. (2007) "Unemployment Benefits, Unemployment Duration, and Post-Unemployment Jobs: A Regression Discontinuity Approach.” The American Economic Review, vol. 97, no. 2, pp. 108-112.

Lohmann, H. and I. Marx, Eds. (2018). Handbook on In-Work Poverty. Cheltenham, UK, Edvard Elgar Publishing.

Navicke, J., Avram, S., and Demmou, L. (2016) "The effects of reform scenarios for unemployment benefits and social assistance on work incentives and poverty in Lithuania”, OECD, Economics Department Working Papers No. 1310.

O'Donoghue, C. (2011). "Do tax-benefit systems cause high replacement rates? A decomposition analysis using EUROMOD”. LABOUR, 25(1), 126-151.

O’Reilly, J., Eichhorst, W., Gábos, A., Hadjivassiliou, K., Lain, D., Leschke, J., ... Villa, P. (2015). "Five Characteristics of Youth Unemployment in Europe: Flexibility, Education, Migration, Family Legacies, and EU Policy". SAGE Open.

OECD (2015). Non-standard work, job polarisation and inequality. In It Together: Why Less Inequality Benefits All. Paris, OECD Publishing.

OECD (2016). "Tax and Benefit Systems: OECD Indicators", http://www.oecd.org/els/benefits-and-wages.htm

Pirttillä, J., \& Selin, H. (2011). "Tax policy and employment: How does the Swedish system fare”. CESifo Working Paper Series No. 3355.

Riddell, C. W., and Song, X. (2011). "The impact of education on unemployment incidence and re-employment success: Evidence from the U.S. labour market". Labour Economics, 18(4), 453-463.

Sutherland, H., and Figari, F. (2013). "EUROMOD: the European Union tax-benefit microsimulation model". International Journal of Microsimulation, 6(1), 4-26. 


\section{Appendix A. Simulating transitions from work to unemployment with EUROMOD}

The approach used in this paper to calculate Participation Tax Rates (PTRs) consists in simulating transitions from work (employment or self-employment) into unemployment for all individuals with positive earnings in the microdata, and re-calculating their new household disposable income by means of the microsimulation model EUROMOD, hence capturing the implications of tax and benefit systems under their new labour market status.

More precisely, we make use of EUROMOD to run two iterations in the tax-benefit system of each country. In the first iteration, EUROMOD simulates tax-benefit instruments and calculates household disposable income without making any changes to the input data. In the second iteration, we simulate transitions to unemployment by setting earnings to zero and adjusting the value of other labour market related variables ${ }^{9}$ for all earners in the input data, and use EUROMOD to recalculate household disposable income under this counterfactual scenario where earners would become unemployed. ${ }^{10}$

In the case of households with multiple earners, household disposable income in unemployment - calculated in the second iteration - is simulated for each earner in turn. Consider for instance a dual earner household. First, household disposable income is simulated before any transitions to unemployment take place (first iteration). Then, we simulate a transition to unemployment for the first earner of the household (by setting their earnings to zero) and calculate household disposable income in case the first earner would become unemployed, keeping the labour market status of the second earner unchanged (second iteration for first earner). Finally, we simulate a transition to unemployment for the second earner and calculate household disposable income in case the second earner enters unemployment, keeping the original labour market status of the first earner unchanged (i.e. first earner in work) (second iteration for second earner).

Once household disposable income in work and in unemployment have been calculated for each earner in the household, the PTR for each earner i in household h can be expressed as:

$$
\mathrm{PTR}_{\mathrm{i}}=1-\frac{\mathrm{Y}_{\mathrm{h}}^{\mathrm{W}_{\mathrm{i}}}-\mathrm{Y}_{\mathrm{h}}^{\mathrm{U}_{\mathrm{i}}}}{\mathrm{E}_{\mathrm{i}}},
$$

where $\mathrm{E}_{\mathrm{i}}$ represents gross earnings of individual $\mathrm{i}$ when they are in work, $\mathrm{Y}_{\mathrm{h}}^{\mathrm{W}_{\mathrm{i}}}$ represents household disposable income when individual $\mathrm{i}$ is in work $\left(\mathrm{W}_{\mathrm{i}}\right)$, and $\mathrm{Y}_{\mathrm{h}}^{\mathrm{U}_{\mathrm{i}}}$ represent household disposable income when individual $\mathrm{i}$ is in unemployment $\left(\mathrm{U}_{\mathrm{i}}\right)$.

Two sets of PTR indicators are presented in the analysis: short-term and long-term PTRs. Short-term PTRs are calculated based on disposable income out of work over the first year of unemployment, meaning that unemployment insurance benefits are taken into account for those individuals eligible for these schemes. Longterm PTRs are calculated based on disposable income out of work assuming that entitlement to unemployment insurance benefits has been exhausted, with social assistance most likely playing a larger role and taking into account entitlement to unemployment assistance, in countries where such schemes are available.

A few assumptions are needed in the simulation of transitions into unemployment to calculate PTRs for those currently in work. First, the number of months in unemployment needs to be specified. Here, unemployment duration is assumed to be equal to months in work during the year before the simulated transition (as reported in the data). This assumption is made in order to compare disposable income in and out of work over the same period of time. Second, in order to simulate unemployment insurance benefits, information about contribution history needs to be provided. Here, we exploit information available in the data and we set the number of months of

\footnotetext{
${ }^{9}$ Months in employment are set to zero, labour market status is set to unemployed, hours of work are set to zero, sector of employment (public or private) is set to zero and firm size is set to zero.

${ }^{10}$ In countries where individuals in the data are observed to receive both unemployment benefits and earnings at the same time, an intermediate iteration is made, where the add-on runs the model after setting unemployment benefits in the data to zero. This is done to avoid having results which mix information on unemployment benefits from two different approaches: reported unemployment benefits and simulated unemployment benefits. The idea behind this intermediate step is to simulate unemployment benefits only for the corresponding period in which the person was in work. In practice, this step affects only a very limited number of observations.
} 
contributions equal to the number of months in work before the transition, which is recorded over the last 12 months. For instance, in order to be eligible for unemployment insurance in Bulgaria, an individual is required to have contributed 9 out of 15 months, while in Germany it is required to have contributed 12 out of 24 months. In our simulations we would consider a person in the data eligible if they have worked 9 out of 12 months before transition to unemployment in Bulgaria; and 12 out of 12 months in Germany (given that month by month employment information is available for the previous year only). For countries where the qualifying period goes beyond 12 months, for instance Lithuania where it is required to contribute 18 out of 36 months, we use information about working history since entering the labour market as an additional control. 


\section{Appendix B. Main characteristics of tax-benefit instruments}

Table 2 Overview of income tax systems, 2017. Note: Monetary amounts expressed as share of annual median equivalised disposable income in each country. ${ }^{\text {a }}$ Refers to the income that is not taxed either through a 0 tax rate at the bottom or a basic tax allowance. Regional tax schedule for Madrid described in Spain. The calculation of the basic tax allowance is based on the income level and includes a progressive element in Slovakia. For Sweden only government tax schedule included. Source: own elaboration based on EUROMOD country reports and European Commission Taxes in Europe database. Median equivalised disposable income table retrieved from Eurostat database on 27 February 2020.

\begin{tabular}{|c|c|c|c|c|c|c|}
\hline Country & Tax unit & $\begin{array}{l}\text { Lowest tax } \\
\text { band limit/ } \\
\text { basic tax } \\
\text { allowance }^{\mathrm{a}} \\
\end{array}$ & $\begin{array}{l}\text { Highest tax } \\
\text { band limit }\end{array}$ & $\begin{array}{l}\text { Lowest/highest rate } \\
(\%)\end{array}$ & Tax credits & Family-related tax provisions \\
\hline $\mathrm{BE}$ & Family & 46.6 & 163.5 & $25 / 50$ & Yes & $\begin{array}{c}\text { Part of taxable income } \\
\text { transferrable to spouse, tax free } \\
\text { amounts for family size and } \\
\text { compostion }\end{array}$ \\
\hline $\mathrm{BG}$ & Individual & - & - & 10 (flat) & No & Children tax allowance \\
\hline $\mathrm{CZ}$ & Individual & - & - & $\begin{array}{c}15 \text { (flat), plus an } \\
\text { additional } 7 \% \text { for } \\
\text { incomes exceeding the } \\
\text { max. contributory base } \\
\text { for SIC }\end{array}$ & Yes & $\begin{array}{l}\text { Spouse tax credit, (refundable) } \\
\text { child tax credit }\end{array}$ \\
\hline DK & Individual & 20.1 & - & $\begin{array}{c}10.08 \text { (bottom income } \\
\text { bracket)/51.95 (sum of } \\
\text { several taxes) }\end{array}$ & Yes & $\begin{array}{l}\text { Unused deductions } \\
\text { transferrable to spouse }\end{array}$ \\
\hline DE & Family & 38.8 & $1,128.4$ & $0 / 45$ & No & $\begin{array}{c}\text { Child tax allowance, single } \\
\text { parent tax allowance, } \\
\text { deduction of childcare } \\
\text { expenses }\end{array}$ \\
\hline $\mathrm{EE}$ & Individual & 20.5 & - & 20 (flat) & No & $\begin{array}{c}\text { Tax allowance for children and } \\
\text { for spouse }\end{array}$ \\
\hline IE & Family & 72.2 & 135.6 & $20 / 40$ & Yes & $\begin{array}{c}\text { Marginal relief for children, } \\
\text { different tax rates and bands } \\
\text { for lone-parents and single } \\
\text { earner }\end{array}$ \\
\hline EL & Individual & 0.0 & 508.7 & $22 / 45$ & Yes & Additional chidren tax credits \\
\hline ES & $\begin{array}{l}\text { Individual } \\
\text { (family } \\
\text { optional) }\end{array}$ & 84.2 & 405.8 & $19 / 43.5$ & Yes & $\begin{array}{c}\text { Personal and familly } \\
\text { allowances (for descendants } \\
\text { and ascendants). Refundable } \\
\text { tax credits for large families } \\
\text { and lone parents, for taxpayers } \\
\text { with disabled descendats or } \\
\text { ascendants and for working } \\
\text { mothers. } \\
\end{array}$ \\
\hline FR & Family & 43.7 & 685.2 & $0 / 45$ & Yes & $\begin{array}{l}\text { Reduction for children at } \\
\text { school and child-care fee }\end{array}$ \\
\hline HR & Individual & 7.6 & 35.2 & $24 / 36$ & No & $\begin{array}{c}\text { Personal allowance for } \\
\text { children and other dependent } \\
\text { relatives }\end{array}$ \\
\hline IT & Individual & 0.0 & 445.3 & $23 / 43$ & Yes & $\begin{array}{l}\text { Child, spouse and other } \\
\text { dependants tax credits }\end{array}$ \\
\hline $\mathrm{CY}$ & Individual & 127.2 & 391.2 & $0 / 35$ & No & - \\
\hline LV & Individual & - & - & 23 (flat) & No & $\begin{array}{l}\text { Allowance for a dependent } \\
\text { child, spouse or parent }\end{array}$ \\
\hline LT & Individual & - & - & 15 (flat) & No & Child tax allowance \\
\hline LU & Family & 28.0 & 496.7 & $0 / 42$ & Yes & Tax bonus for children \\
\hline $\mathrm{HU}$ & Individual & - & - & 15 (flat) & Yes & Family tax allowance \\
\hline MT & $\begin{array}{l}\text { Individual } \\
\text { (family } \\
\text { optional) }\end{array}$ & 61.6 & 405.9 & $0 / 35$ & Yes & Private childcare tax credit \\
\hline NL & Individual & 83.202865 & 279.28048 & $8.9 / 52$ & Yes & $\begin{array}{c}\text { Child allowance, single parent } \\
\text { supplement }\end{array}$ \\
\hline AT & Individual & 43.7 & $3,972.0$ & $0 / 55$ & Yes & $\begin{array}{l}\text { Child tax credit, child tax } \\
\text { allowance, lone parent/single } \\
\text { earner allowance }\end{array}$ \\
\hline
\end{tabular}




\begin{tabular}{|l|c|c|c|c|c|c|}
\hline PL & $\begin{array}{c}\text { Individual } \\
\text { (family } \\
\text { optional) }\end{array}$ & 2.0 & 305.6 & $18 / 32$ & Yes & Child tax credit \\
\hline PT & Family & 75.9 & 862.8 & $14.5 / 48.0$ & Yes & $\begin{array}{c}\text { Child tax credit and depedent } \\
\text { parent tax credit. Personal and } \\
\text { family allowances }\end{array}$ \\
\hline RO & Individual & - & - & 10 (flat) & Yes & Tax allowance for dependents \\
\hline SI & Individual & 0.0 & 535.4 & $16 / 50$ & Yes & Family tax allowances \\
\hline SK & Individual & 0.0 & 469.3 & $19 / 25$ & Yes & $\begin{array}{c}\text { Spouse tax allowance, child } \\
\text { tax credit }\end{array}$ \\
\hline FI & Individual & 68.9 & 297.8 & $6 / 31.25$ & Yes & Child tax credit \\
\hline SE & Individual & 178.4 & 259.5 & $0 / 25$ & Yes & - \\
\hline UK & Individual & 61.9 & 807.7 & $20 / 45$ & Yes & - \\
\hline
\end{tabular}

Table 3 Overview of employee social insurance contributions, 2017. Note: Monetary amounts expressed as share of monthly median equivalised disposable income in each country. Most Danish transfers are financed through either the tax system, the exception are the supplementary labour market pension scheme and voluntary flatrate contributions to the unemployment insurance and early retirement scheme. The ceiling in Luxembourg refers to long-term care contributions only. For Malta, the floor and ceiling refer to minimum and maximum payable amounts. Source: own elaboration based on EUROMOD country reports. Median equivalised disposable income table retrieved from Eurostat database on 27 February 2020.

\begin{tabular}{|l|c|c|c|c|}
\hline Country & Rate (\%) & Floor & Ceiling & Tax deductible \\
\hline BE & 13 & - & - & Yes \\
\hline BG & 13.34 & 78.6 & 444.3 & Yes \\
\hline CZ & 11 & - & 566.4 & No \\
\hline DK & - & - & - & No \\
\hline DE & 20.775 & - & - & Yes \\
\hline EE & 3.6 & - & - & No \\
\hline IE & 4 & 73.6 & - & Yes \\
\hline EL & 16 & - & 894.3 & Yes \\
\hline ES & 6.35 & 67.0 & 304.5 & Yes \\
\hline FR & 18.804 & - & $1,412.3$ & Yes \\
\hline HR & 20 & 71.0 & $1,121.1$ & Yes \\
\hline IT & 9.49 & 62.0 & 595.6 & Yes \\
\hline CY & 7.8 & 0.5 & 354.7 & No \\
\hline LV & 10.5 & - & 714.6 & No \\
\hline LT & 9 & - & - & No \\
\hline LU & 4.45 & 59.6 & 297.8 & Yes \\
\hline HU & 17 & - & - & - \\
\hline MT & 10 & 6.0 & 15.5 & Yes \\
\hline NL & - & - & - & Yes \\
\hline AT & 18.12 & 20.3 & 237.4 & No \\
\hline PL & 13.71 & - & 457.0 & Yes \\
\hline PT & 11 & - & - & Yes \\
\hline RO & 11 & - & - & Yes \\
\hline SI & 22.1 & - & - & Yes \\
\hline SK & 9.4 & - & - & No \\
\hline FI & 9.33 & 2.8 & - & - \\
\hline SE & 7 & 0.4 & & \\
\hline UK & $12+2$ (if above upper earnings limit) & & & \\
\hline
\end{tabular}

Table 4 Overview of self-employed social insurance contributions, 2017. Note: Monetary amounts expressed as share of monthly median equivalised disposable income in each country. Minimum base is applied to selfemployment income below. A minimum contribution of $€ 500 /$ year applies in Ireland. Rates differet by income level in France. The contribution base is not income related but is a lump-sum obtained as a percentage of the average gross wage of the previous year in Croatia and Poland. Source: own elaboration based on EUROMOD country reports. Median equivalised disposable income table retrieved from Eurostat database on 27 February 2020 .

\begin{tabular}{|l|c|c|c|c|}
\hline Country & Rate $(\%)$ & Floor & Ceiling & Tax deductible \\
\hline BE & 21 & 11.8 & 67.0 & Yes \\
\hline BG & 26.8 & - & 444.3 & Yes \\
\hline
\end{tabular}




\begin{tabular}{|c|c|c|c|c|}
\hline $\mathrm{CZ}^{\mathrm{a}}$ & 45 & 35.4 & 566.4 & No \\
\hline DK & - & - & - & - \\
\hline $\mathrm{DE}$ & 34.4 & - & - & No \\
\hline $\mathrm{EE}^{\mathrm{a}}$ & 39 & 49.0 & 798.2 & Yes \\
\hline $\mathrm{IE}$ & 4 & 20.1 & - & No \\
\hline $\mathrm{EL}^{\mathrm{a}}$ & $26.95+€ 10$ monthly flat rate & 89.4 & 894.4 & Yes \\
\hline $\mathrm{ES}^{\mathrm{a}}$ & 29.8 & 72.5 & 304.5 & Yes \\
\hline FR & & & 176.5 & Yes \\
\hline $\mathrm{HR}$ & 37.2 & - & - & Yes \\
\hline IT & 31.08 & 92.3 & 456.4 & Yes \\
\hline $\mathrm{CY}$ & 14.6 & - & 151.6 & Yes \\
\hline LV & 31.13 & 62.2 & - & No \\
\hline LT & 30.8 & 0.0 & 301.0 & No \\
\hline LU & 37.5 & 59.6 & - & Yes \\
\hline $\mathrm{HU}^{\mathrm{a}}$ & 40.5 & 91.2 & 473.6 & No \\
\hline $\mathrm{MT}^{\mathrm{a}}$ & 15 & 10.2 & 23.2 & Yes \\
\hline NL & - & - & - & - \\
\hline $\mathrm{AT}^{\mathrm{a}}$ & $27.68+€ 9.33$ per month flat-rate & 20.3 & 276.9 & Yes \\
\hline PL & 31.9 & - & - & Yes \\
\hline PT & 29.6 & & - & No \\
\hline RO & 26.3 & 250.4 & - & Yes \\
\hline $\mathrm{SI}^{\mathrm{a}}$ & 38.2 & 80.9 & 488.5 & Yes \\
\hline SK & 33.15 & 71.0 & 994.0 & Yes \\
\hline FI & 25.74 & 31.1 & - & Yes \\
\hline SE & 28.97 & 0.4 & - & No \\
\hline UK & $£ 2.85$ flat-rate per week & 32.4 & - & No \\
\hline
\end{tabular}

Table 5 Overview of unemployment benefits, 2017. Note: Contribution period refers to months of contributions/period in which contributions can be made. In Cyprus, eligibility is defined in terms of the amount paid in contributions 26 weeks before unemployment. Min. stands for presence of a floor in unemployment insurance (UI) payment. Max. stands for the presence of a ceiling in UI payment. UA unemployment assistance; SIC - social insurance contribution. Source: own elaboration based on EUROMOD country reports and MISSOC (March 2018).

\begin{tabular}{|c|c|c|c|c|c|c|}
\hline Country & $\begin{array}{l}\text { Contribution } \\
\text { period } \\
\text { (months) }\end{array}$ & Payment & $\begin{array}{l}\text { Duration } \\
\text { (months) }\end{array}$ & $\begin{array}{l}\text { Self-employed } \\
\text { eligible }\end{array}$ & $\begin{array}{l}\text { Unemployment } \\
\text { assistance }\end{array}$ & $\begin{array}{l}\text { Income taxes } \\
\text { and SICs paid } \\
\text { on UI }\end{array}$ \\
\hline $\mathrm{BE}$ & $\begin{array}{c}12 / 21 \\
(\text { age }<36), \\
18 / 33(\text { age } \geq 36 \\
\& \text { age }<50), \\
24 / 42 \\
(\text { age } \geq 50)\end{array}$ & $\begin{array}{l}65 \% \text { falling to } 40 \% \text { of } \\
\text { gross earnings, then } \\
\text { minimum amount. Min. } \\
\& \text { max. }\end{array}$ & $\begin{array}{l}36 \text { (no } \\
\text { limit) }\end{array}$ & No & - & Tax \\
\hline BG & $9 / 24$ & $\begin{array}{c}60 \% \text { of gross earnings. } \\
\text { Min. }\end{array}$ & $4-12$ & No & - & Neither \\
\hline $\mathrm{CZ}$ & $12 / 24$ & $\begin{array}{c}65 \% \text { falling to } 45 \% \text { of } \\
\text { net earnings. Min. \& } \\
\text { max. }\end{array}$ & 5,8 or 11 & Yes & - & Neither \\
\hline DK & $12 / 36$ & $\begin{array}{c}90 \% \text { of gross earnings. } \\
\text { Max. }\end{array}$ & 24 & Yes & - & Tax \\
\hline $\mathrm{DE}$ & $12 / 24$ & $\begin{array}{c}\text { 67-60\% of net earnings. } \\
\text { Max. }\end{array}$ & $6-24$ & No & Means-tested UA & $\begin{array}{l}\text { Indirectly (tax } \\
\text { applied on } \\
\text { taxable income } \\
\text { increases if UI } \\
\text { received) } \\
\end{array}$ \\
\hline $\mathrm{EE}$ & $12 / 36$ & $\begin{array}{l}50 \% \text { falling to } 40 \% \text { of } \\
\text { gross earnings. Min. \& } \\
\text { max. }\end{array}$ & $6-12$ & No & Flat UA & $\begin{array}{l}\text { Tax and } \\
\text { reduced SICs }\end{array}$ \\
\hline IE & $9 / 12$ & $\begin{array}{l}\text { Fixed amounts based on } \\
\text { previous earnings. Min. } \\
\qquad \& \text { max. }\end{array}$ & 9 & No & Means-tested UA & $\begin{array}{c}\text { Tax (except } \\
\text { child- } \\
\text { dependent } \\
\text { element) }\end{array}$ \\
\hline EL & $5 / 14$ & $\begin{array}{l}\text { Flat rate with increase } \\
\text { for dependents. }\end{array}$ & $5-12$ & $\begin{array}{l}\text { Under stricter } \\
\text { conditions (not } \\
\text { simulated) }\end{array}$ & $\begin{array}{l}\text { Flat UA (means- } \\
\text { tested) }\end{array}$ & $\begin{array}{c}\text { Tax (if taxable } \\
\text { income } \\
>€ 10,000 / \text { year) }\end{array}$ \\
\hline
\end{tabular}




\begin{tabular}{|c|c|c|c|c|c|c|}
\hline ES & $\begin{array}{c}12 / 72 \\
\text { (employees), } \\
12 / 24 \text { (self- } \\
\text { employed) }\end{array}$ & $\begin{array}{l}70 \% \text { falling to } 50 \% \text { of } \\
\text { previous contributory } \\
\text { base. Min. \& max. }\end{array}$ & $4-24$ & $\begin{array}{c}\text { Yes if } \\
\text { voluntarily } \\
\text { insured }\end{array}$ & Means-tested UA & Tax and SICs \\
\hline FR & $4 / 28$ & $\begin{array}{c}40.4 \% \text { of gross } \\
\text { earnings + fixed } \\
\text { allocation. Min. \& max. }\end{array}$ & $\begin{array}{l}\text { Max. } \\
24(36)\end{array}$ & No & Means-tested UA & $\begin{array}{l}\text { Tax and } \\
\text { reduced SICs }\end{array}$ \\
\hline HR & $9 / 24$ & $\begin{array}{l}70 \% \text { falling to } 35 \% \text { of } \\
\text { gross earnings minus } \\
\text { SICs. Min. \& max. }\end{array}$ & $3-15$ & Yes & - & Neither \\
\hline IT & $12 / 24$ & $\begin{array}{l}75 \% \text { falling to } 60 \% \text { of } \\
\text { gross earnings. Min. \& } \\
\text { Max. }\end{array}$ & $10-12$ & No & - & Tax \\
\hline $\mathrm{CY}$ & 6 & $\begin{array}{l}60 \% \text { of basic insurable } \\
\text { earnings + increases for } \\
\text { dependents. }\end{array}$ & 6 & No & - & Neither \\
\hline LV & $12 / 16$ & $\begin{array}{c}50-65 \% \text { of gross } \\
\text { earnings; reduces with } \\
\text { length of unemployment. }\end{array}$ & 9 & No & - & Neither \\
\hline LT & $12 / 30$ & $\begin{array}{c}\text { Flat rate }+40 \% \text { falling to } \\
20 \% \text { of gross earnings. } \\
\text { Max. }\end{array}$ & 9 & No & - & Tax \\
\hline LU & $6 / 12$ & $\begin{array}{l}\text { 80-85\% of gross } \\
\text { earnings. Max. }\end{array}$ & 12 & Yes & - & Tax and SICs \\
\hline $\mathrm{HU}$ & $12 / 36$ & $\begin{array}{l}60 \% \text { of gross earnings. } \\
\text { Min \& max. }\end{array}$ & 3 & Yes & $\begin{array}{l}\text { Flat UA (means- } \\
\text { tested) }\end{array}$ & Tax and SICs \\
\hline MT & $5 / 24$ & Flat rate. & 6 & $\begin{array}{c}\text { Yes if } \\
\text { contributed SIC }\end{array}$ & Means-tested UA & Neither \\
\hline NL & $26 / 36$ weeks & $\begin{array}{l}75 \% \text { falling to } 70 \% \text { of } \\
\text { gross earnings. Max. }\end{array}$ & $3-32$ & No & - & Tax and SICs \\
\hline AT & $\begin{array}{c}12 / 24 \\
(\text { age } \geq 25), 6 / 12 \\
(\text { age }<25)\end{array}$ & $\begin{array}{l}55 \% \text { of net earnings; } \\
\text { Min., max. }\end{array}$ & $4.6-36$ & No & Means-tested UA & $\begin{array}{l}\text { Indirectly (tax } \\
\text { applied on } \\
\text { taxable income } \\
\text { increases if UI } \\
\text { received) }\end{array}$ \\
\hline PL & $12 / 18$ & $\begin{array}{l}\text { Flat rate; reduced after } 3 \\
\text { months. Min. \& max. }\end{array}$ & $6-12$ & Yes & - & Tax and SICs \\
\hline PT & $12 / 24$ & $\begin{array}{l}65 \% \text { falling to } 55 \% \text { of } \\
\text { gross earnings. Min \& } \\
\text { max. }\end{array}$ & $5-18$ & No & Means-tested UA & Neither \\
\hline RO & $12 / 24$ & $\begin{array}{c}\text { Flat rate } \\
\text { component }+3 \% \text { to } 10 \% \\
\text { of gross earnings. }\end{array}$ & $6-12$ & No & - & Tax \\
\hline SI & $\begin{array}{l}9 / 24(\text { age } \geq 30), \\
6 / 24(\text { age }<30)\end{array}$ & $\begin{array}{l}80 \% \text { falling to } 50 \% \text { of } \\
\text { gross earnings. Min \& } \\
\text { max. }\end{array}$ & $2-25$ & Yes & - & Tax and SICs \\
\hline SK & $24 / 36$ & $\begin{array}{c}50 \% \text { of previous } \\
\text { contributory base. Max. }\end{array}$ & 6 & No & - & Neither \\
\hline FI & $\begin{array}{c}6 / 28 \\
\text { (employees), } \\
\text { 15/48 (self- } \\
\text { employed) }\end{array}$ & $\begin{array}{c}\text { Basic component }+45 \% \\
\text { difference between net } \\
\text { daily wage and basic } \\
\text { allowance }+20 \% \\
\text { difference between daily } \\
\text { wage and daily } \\
\text { limit + child } \\
\text { supplements. } \\
\text { Min \& Max } \\
\end{array}$ & 13 & Yes & Means-tested UA & $\begin{array}{l}\text { Tax and health } \\
\text { insurance } \\
\text { contribution for } \\
\text { medical care }\end{array}$ \\
\hline SE & $6 / 12$ & $\begin{array}{l}80 \% \text { falling to } 65 \% \text { of } \\
\text { gross earnings. Min \& } \\
\text { max. }\end{array}$ & $12-15$ & Yes & - & Tax and SICs \\
\hline UK & $24 / 24$ & $\begin{array}{c}\text { Flat rate depending on } \\
\text { age. }\end{array}$ & 6 & No & Means-tested UA & Tax \\
\hline
\end{tabular}

Table 6 Overview of social assistance benefits, 2017. Note: Monetary amounts expressed as share of monthly median equvalised disposable income in each country. Maximum amount for a single individual. Source: own 
elaboration based on EUROMOD country reports and MISSOC (March 2018). Median equivalised disposable income table retrieved from Eurostat database on 27 February 2020.

\begin{tabular}{|c|c|c|c|c|}
\hline Country & Name & $\begin{array}{c}\text { Max amount } \\
\text { per month }\end{array}$ & $\begin{array}{l}\text { Income taxes and } \\
\text { SICs paid on SA }\end{array}$ & $\begin{array}{l}\text { Eligibility } \\
\text { if in work }\end{array}$ \\
\hline $\mathrm{BE}$ & Leefloon / revenu d'integration sociale & 44.7 & Neither & Yes \\
\hline BG & месечна социалнапомощ поради ниски доходи & $\begin{array}{c}73 \text { of } \\
\text { differentiated } \\
\text { minimum } \\
\text { income }\end{array}$ & Neither & Yes \\
\hline $\mathrm{CZ}$ & Allowance for Living & 18.5 & Neither & Yes \\
\hline DK & $\begin{array}{l}\text { Kontanthjælp; Aktivering af kontanthjælpsmodtagere; } \\
\text { Integrationsydelse }\end{array}$ & 79.4 & Tax & No \\
\hline$\overline{\mathrm{DE}}$ & Sozialhilfe & 21.6 & Neither & No \\
\hline EE & Toimetulekutoetus & 14.8 & Neither & Yes \\
\hline $\mathrm{IE}$ & Supplementary Welfare Allowance & 9.2 & Neither & Yes \\
\hline EL & Guaranteed minimum income (KEA) & 30.5 & $\begin{array}{c}\text { Tax (solidarity } \\
\text { contribution) }\end{array}$ & Yes \\
\hline ES & $\begin{array}{l}\text { Regional Minimum Income Schemes (Rentas Mínimas de } \\
\text { Inserción) }\end{array}$ & 24.3 to 52.6 & Neither & No \\
\hline FR & $\begin{array}{l}\text { Revenu minimum d'insertion RMI/Revenue de solidarité } \\
\text { active (RSA) }\end{array}$ & 32.5 & $\begin{array}{c}\text { Allowance of } \\
\text { specific solidarity } \\
\text { subject to taxation }\end{array}$ & $\begin{array}{c}\text { No } \\
\text { (different } \\
\text { benefit for } \\
\text { low income } \\
\text { worker) }\end{array}$ \\
\hline HR & $\begin{array}{l}\text { Subsistence benefit (Pomoć za uzdržavanje, Stalna pomoć, } \\
\text { Zajamčena minimalna naknada) }\end{array}$ & 19.3 & Neither & No \\
\hline IT & None at national level & - & - & - \\
\hline $\mathrm{CY}$ & Guaranteed Minimum Income $(\Delta \eta \mu$ ó & 37.6 & Neither & Yes \\
\hline LV & $\begin{array}{l}\text { Guaranteed Minimum Income (Garantētā minimālā } \\
\text { ienākuma pabalsts) }\end{array}$ & 8.1 & Neither & Yes \\
\hline LT & Social benefit (socialine pasalpa) & 17.8 & Neither & Yes \\
\hline LU & Social assistance (Revenu minimum garanti) & 41.8 & $\begin{array}{c}\text { Tax; health and } \\
\text { long-term care } \\
\text { SICs }\end{array}$ & Yes \\
\hline $\mathrm{HU}$ & Social Assistance (Szociàlis Segèlyek) & 17.0 & Neither & No \\
\hline MT & Social assistance (Ghajnuna Socjali) & 33.5 & Neither & No \\
\hline $\mathrm{NL}$ & Social Assistance & 48.0 & Both & Yes \\
\hline AT & $\begin{array}{l}\text { Minimum Income Benefit (Bedarfsorientierte } \\
\text { Mindestsicherung) }\end{array}$ & 40.3 & Neither & Yes \\
\hline PL & (Permanent) Social Assistance & 25.9 & Neither & Yes \\
\hline PT & $\begin{array}{l}\text { Social integration income (Rendimento social de inserção } \\
\text { ou mínimo garantido) }\end{array}$ & 54.1 & Neither & Yes \\
\hline $\mathrm{RO}$ & Guaranteed min income (Venitul minim garantat) & 11.3 & Neither & Yes \\
\hline SI & Social Assistance & 26.5 & Neither & Yes \\
\hline SK & $\begin{array}{l}\text { Material needs benefit (Dávka v hmotnej núdzi a } \\
\text { príspevky k dávke) }\end{array}$ & 29.0 & Neither & Yes \\
\hline FI & Local authority income support & 23.9 & Neither & Yes \\
\hline SE & Social Assistance & 19.2 & Neither & Yes \\
\hline UK & Income support, Income-Based Jobseeker's Allowance & 18.9 & Neither & Yes \\
\hline
\end{tabular}

Table 7 Overview of simulated other benefits. Note: the table gives an overview simulated family/education and pension/disability/health benefits but not all of them are affected by transitions from employment to unemployment or by increases in earnings. Source: own representation based on EUROMOD version H1.0

\begin{tabular}{|c|c|c|}
\hline & Family and education benefits & Pensions, disability and health benefits \\
\hline Austria & $\begin{array}{l}\text { Child benefit and child tax credit, family bonus, child } \\
\text { care benefit and supplement }\end{array}$ & - \\
\hline Belgium & Child benefits, birth allowance, child care allowance & - \\
\hline Bulgaria & Maternity benefits, child benefits, birth grant & - \\
\hline Croatia & $\begin{array}{l}\text { Child benefit, parental and maternity leave benefit and } \\
\text { allowance, birth grant }\end{array}$ & - \\
\hline Cyprus & $\begin{array}{l}\text { Child benefit and supplement, birth grant, student } \\
\text { grant }\end{array}$ & - \\
\hline Czech Republic & $\begin{array}{l}\text { Birth grant, child benefit, parental allowances, income } \\
\text { tax bonus }\end{array}$ & - \\
\hline Denmark & Child benefits, child family grant & $\begin{array}{l}\text { Old-age pension, supplementary pension, pension } \\
\text { supplement }\end{array}$ \\
\hline Estonia & $\begin{array}{l}\text { Child care allowance, birth grant, child and family } \\
\text { benefit, large family parent allowance }\end{array}$ & Support for pensioners living alone \\
\hline
\end{tabular}




\begin{tabular}{|c|c|c|}
\hline Finland & Child benefit, child home care allowance, study grant & Guarantee pension \\
\hline France & $\begin{array}{l}\text { Child benefit, birth grant, family support allowance, } \\
\text { educational allowance, benefit for large families, } \\
\text { benefit for young children }\end{array}$ & $\begin{array}{l}\text { Means-tested disability benefit and widow allowance, } \\
\text { solidarity allowance for elderly }\end{array}$ \\
\hline Germany & $\begin{array}{l}\text { Child benefit, additional child benefit, maternity and } \\
\text { parental leave benefit, education benefit }\end{array}$ & $\begin{array}{l}\text { Long-term care benefits from statutory accident } \\
\text { insurance, disability pension, sickness benefit }\end{array}$ \\
\hline Greece & $\begin{array}{l}\text { Child benefit, large family benefit, civil servants' } \\
\text { family benefit }\end{array}$ & $\begin{array}{l}\text { Compensations for survivor and old-age pension } \\
\text { reduction }\end{array}$ \\
\hline Hungary & $\begin{array}{l}\text { Maternity grant, child raising support and child care } \\
\text { allowance, child protection benefit, family allowance }\end{array}$ & - \\
\hline Ireland & $\begin{array}{l}\text { Child benefit, maternity benefit, family income } \\
\text { supplement, one parent family payment }\end{array}$ & $\begin{array}{l}\text { Illness and injury benefit, disability allowance, } \\
\text { invalidity pension, widow pension, state pension }\end{array}$ \\
\hline Italy & Newborn bonus, family allowances & Social pension \\
\hline Latvia & $\begin{array}{l}\text { Maternity and paternity benefit, child birth benefit, } \\
\text { child care benefit, family state benefit, parental } \\
\text { benefit }\end{array}$ & $\begin{array}{l}\text { State social security benefit for survivor, old-age state } \\
\text { social security benefit }\end{array}$ \\
\hline Lithuania & $\begin{array}{l}\text { Child allowance, birth grant, pregnancy grant, } \\
\text { maternity and paternity leave benefits, student's } \\
\text { childcare benefit, benefit for multiple birth families }\end{array}$ & - \\
\hline Luxembourg & $\begin{array}{l}\text { Maternity allowance, education allowance, new } \\
\text { school year allowance, child benefit }\end{array}$ & - \\
\hline Malta & Child allowance, social assistance for single parents & Contributory pensions \\
\hline Netherlands & Child benefit, family allowance & State pension, survivor pension, care allowance \\
\hline Poland & $\begin{array}{l}\text { Child benefit, child birth supplement, child allowance, } \\
\text { child care allowance, supplement for large families, } \\
\text { lone parents, disabled chldren and starting school } \\
\text { year, parental allowance }\end{array}$ & $\begin{array}{l}\text { (Special) nursing allowance, nursing benefit, } \\
\text { complementary old-age pension }\end{array}$ \\
\hline Portugal & Child benefit & Social pension, contributory old-age pension \\
\hline Romania & $\begin{array}{l}\text { Family benefit, child raising allowance and support, } \\
\text { child benefit, educational allowance }\end{array}$ & Minimum social pension \\
\hline Slovakia & $\begin{array}{l}\text { Child benefit, birth grant, tax refunds, parental } \\
\text { allowance }\end{array}$ & - \\
\hline Slovenia & Parental benefit and allowance, child benefit & - \\
\hline Spain & $\begin{array}{l}\text { Child benefits, large family benefit, birth grand, } \\
\text { multiple birth benefit, working mother refundable tax } \\
\text { credit, working lone parent tax credit, working large } \\
\text { families tax credit }\end{array}$ & $\begin{array}{l}\text { Widow/er's pension complement, non-contributory } \\
\text { old-age pension, pension complement benefit }\end{array}$ \\
\hline Sweden & Child benefit & - \\
\hline United Kingdom & Child benefit, child tax credit & $\begin{array}{l}\text { Income related ESA, winter fuel allowance, pension } \\
\text { credit }\end{array}$ \\
\hline
\end{tabular}




\section{Appendix C. Tables and Figures}

Fig. 6 Short-term PTRs vs. unemployment rates in 2017. Note: average values shown. Source: own calculations using EUROMOD version H1.0 and EUROSTAT information on unemployment rates

(https://ec.europa.eu/eurostat/databrowser/view/tps00203/default/table?lang=en.)
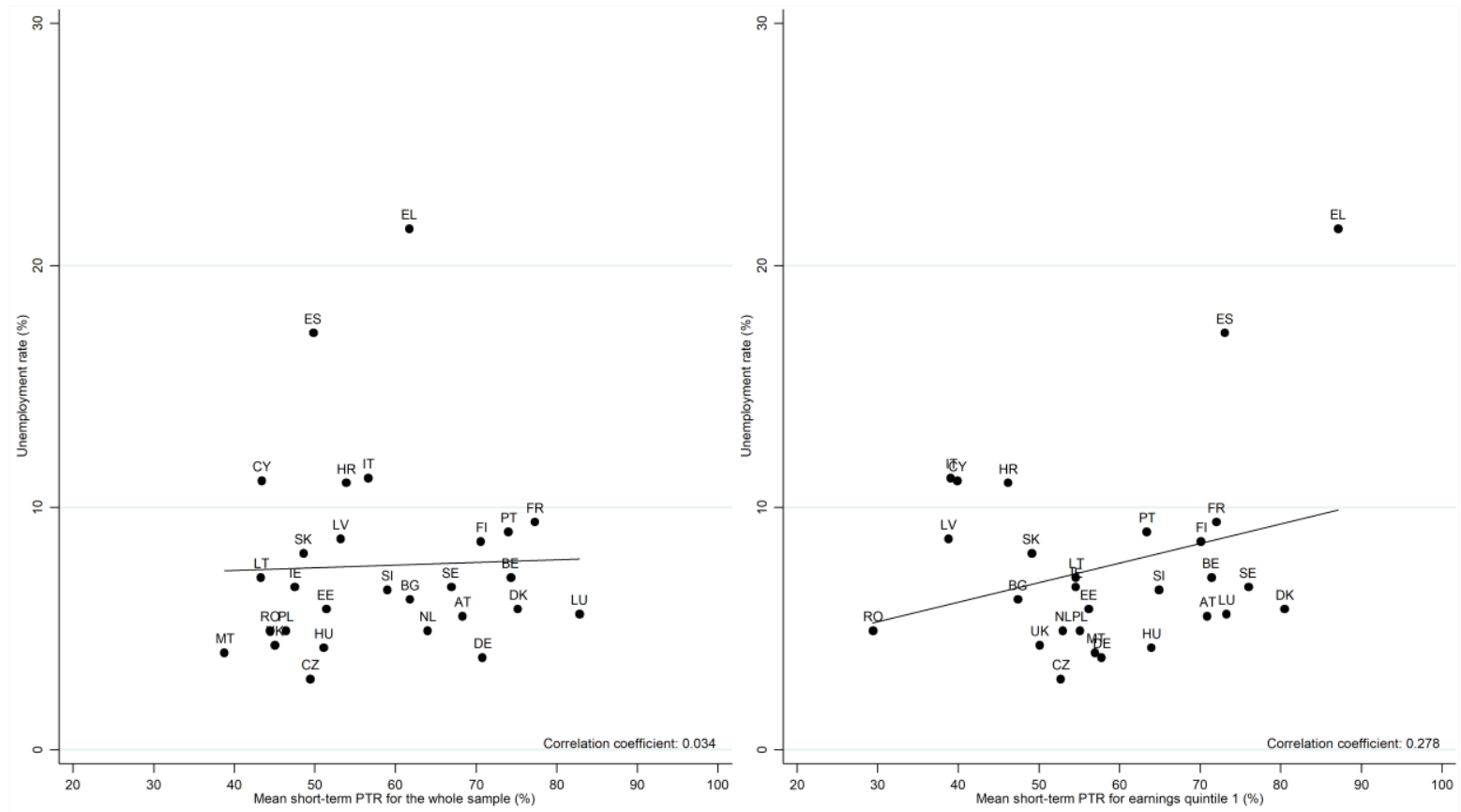

Fig. 7 Distribution of short-term PTRs in 2017. Note: countries ranked by mean short-term PTRs. Source: own calculations using EUROMOD version H1.0

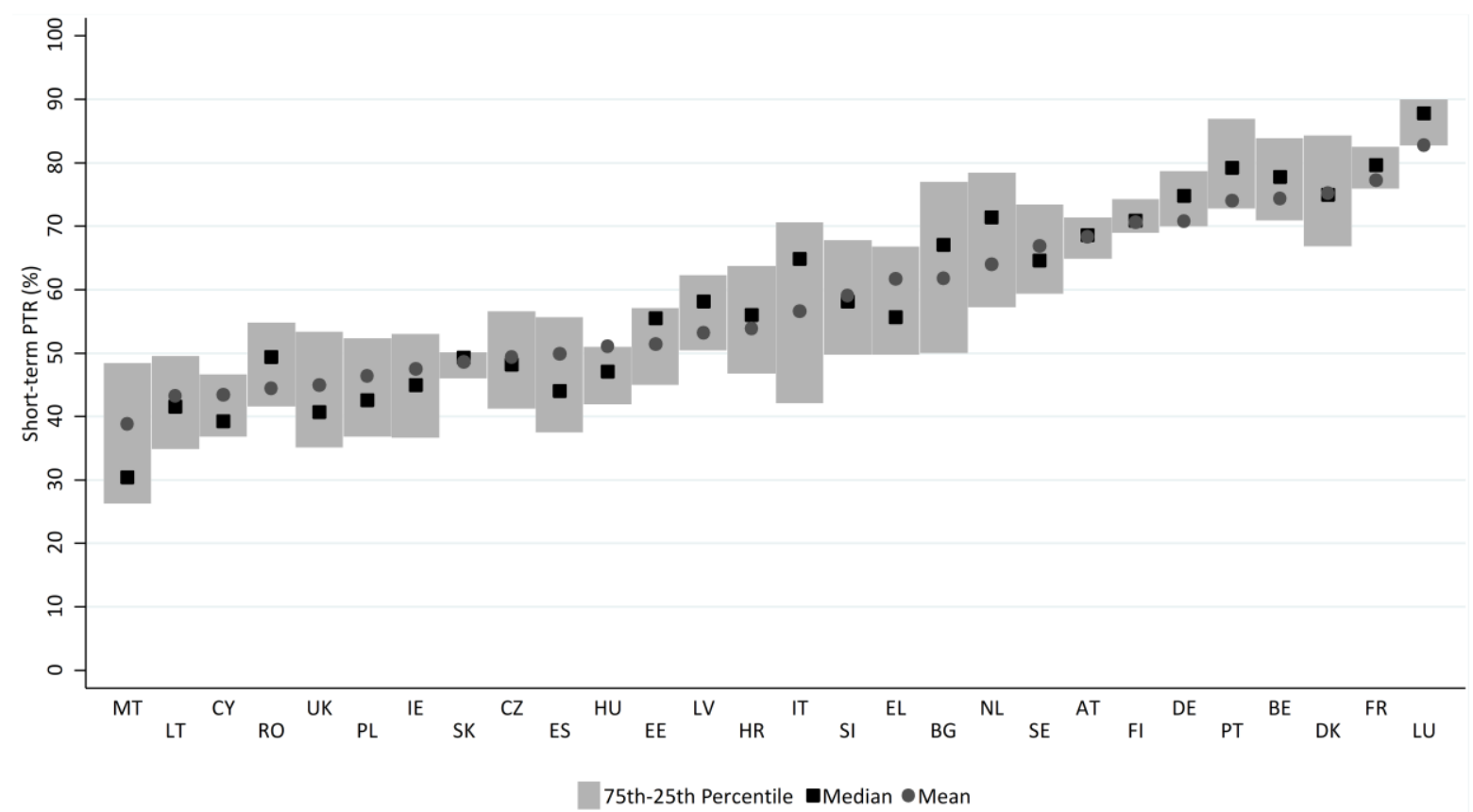


Fig. 8 Distribution of long-term PTRs in 2017. Note: countries ranked by mean long-term PTRs. Source: own calculations using EUROMOD version H1.0

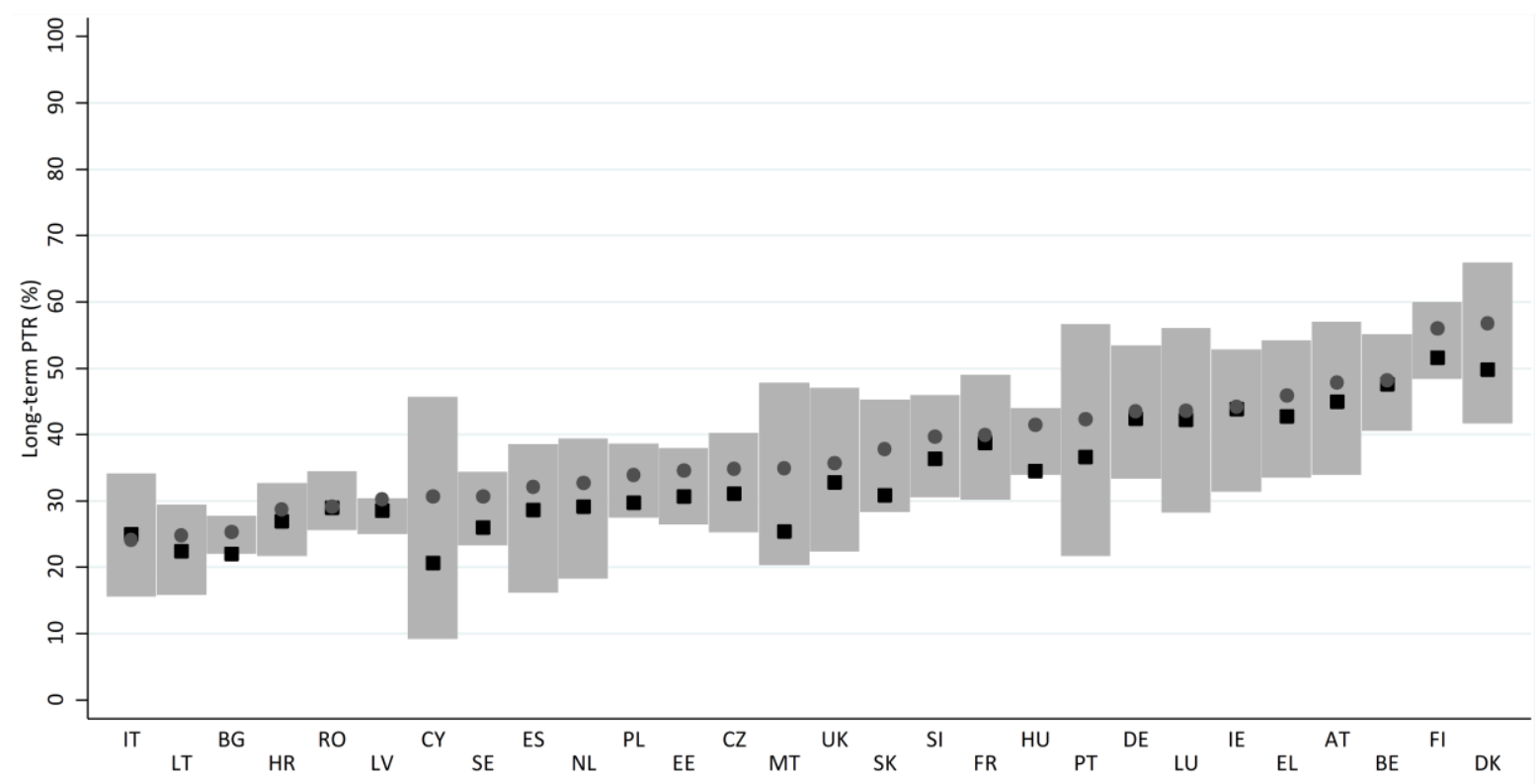

75th-25th Percentile $\mathbf{m e d i a n} \bullet$ Mean

Fig. 9 Distribution of METRs in 2017. Note: countries ranked by mean METR. Source: own calculations using EUROMOD version H1.0

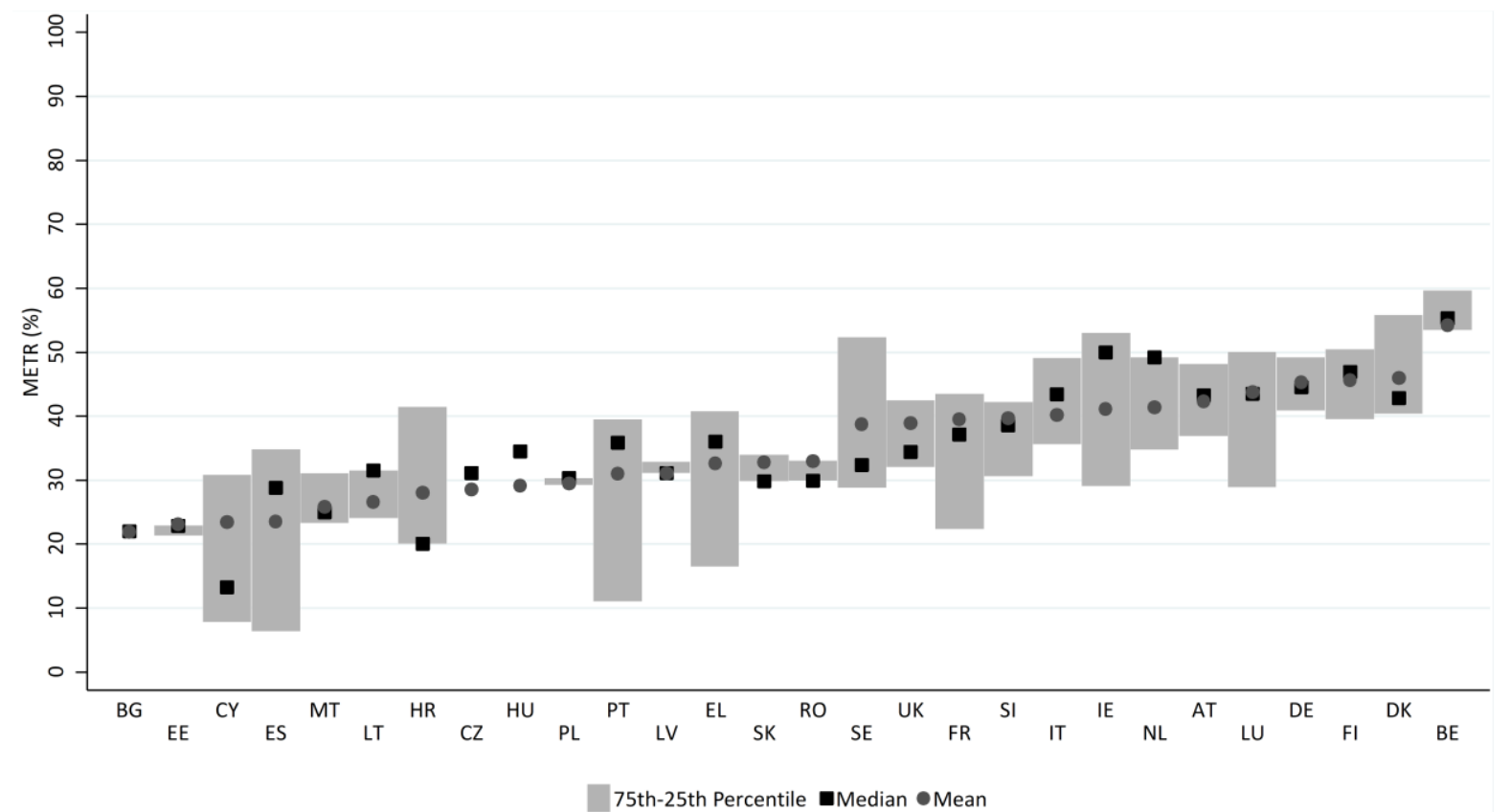


Fig. 10 Relative contribution of benefits vs. income taxes and social insurance contributions to mean short-term PTRs in 2017. Source: own calculations using EUROMOD version H1.0

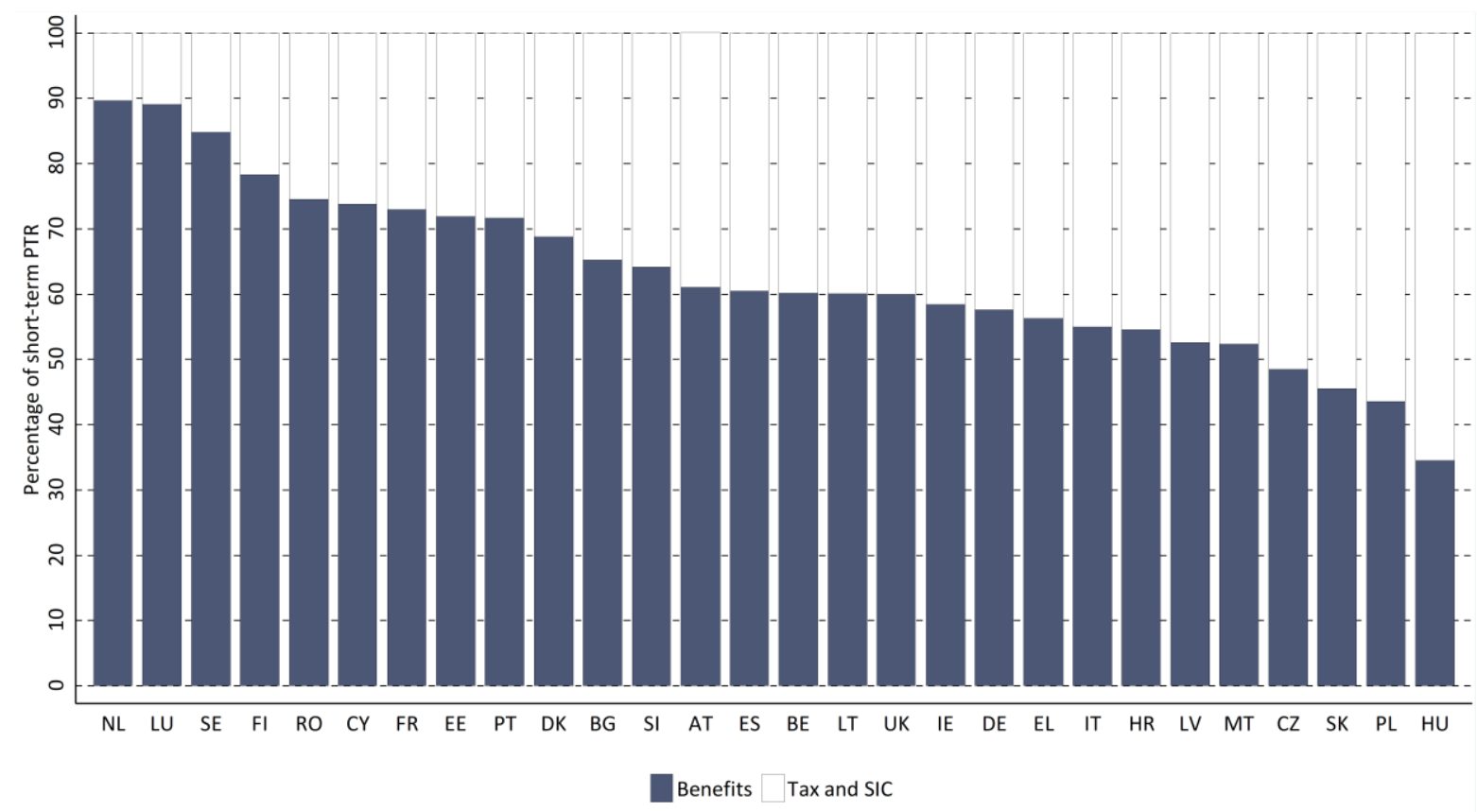

Fig. 11 Relative contribution of benefits vs. income taxes and social insurance contributions to mean long-term PTRs in 2017. Source: own calculations using EUROMOD version H1.0

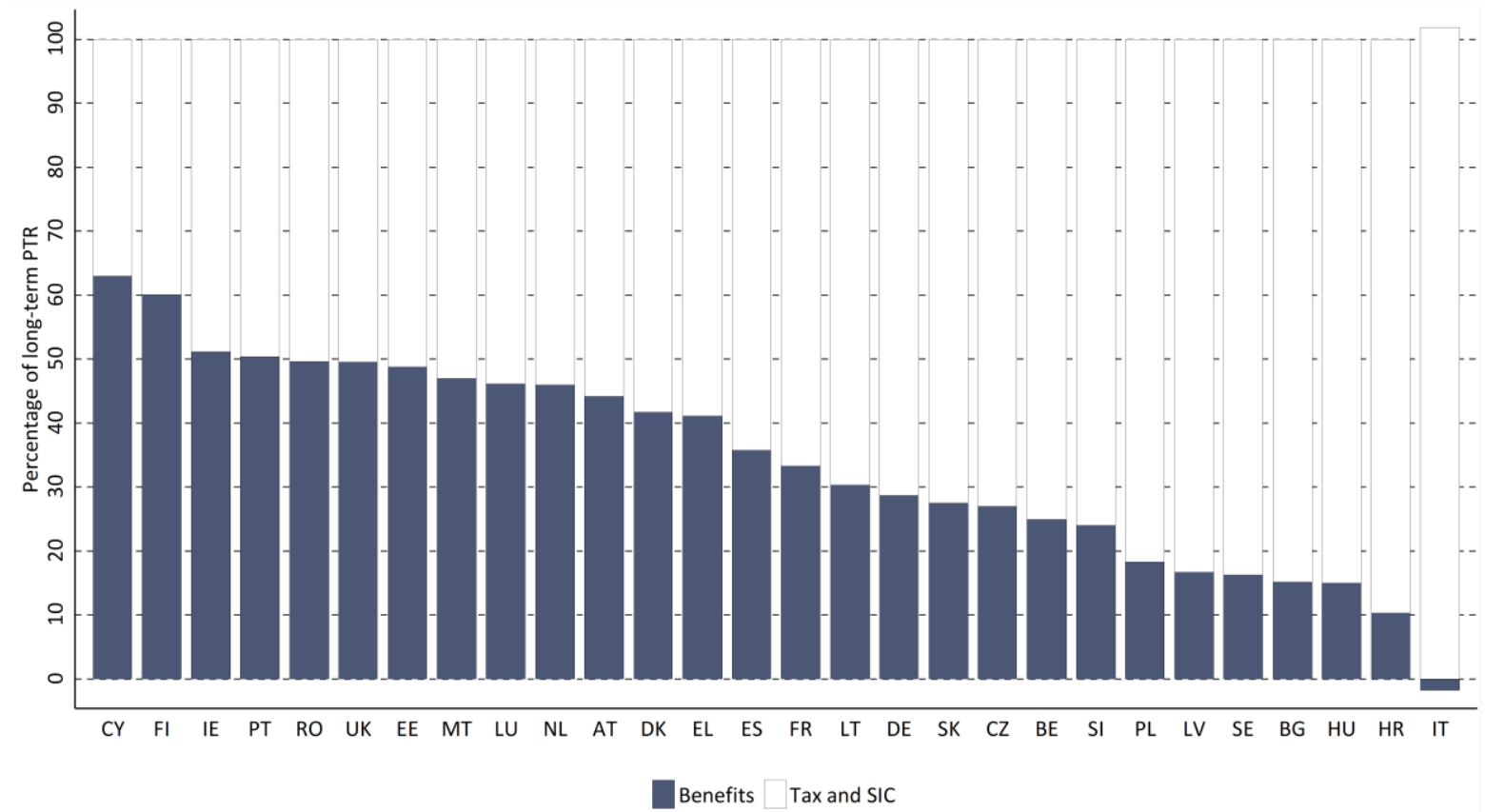


Fig. 12 Relative contribution of benefits vs. income taxes and social insurance contributions to mean METRs in 2017. Source: own calculations using EUROMOD version H1.0

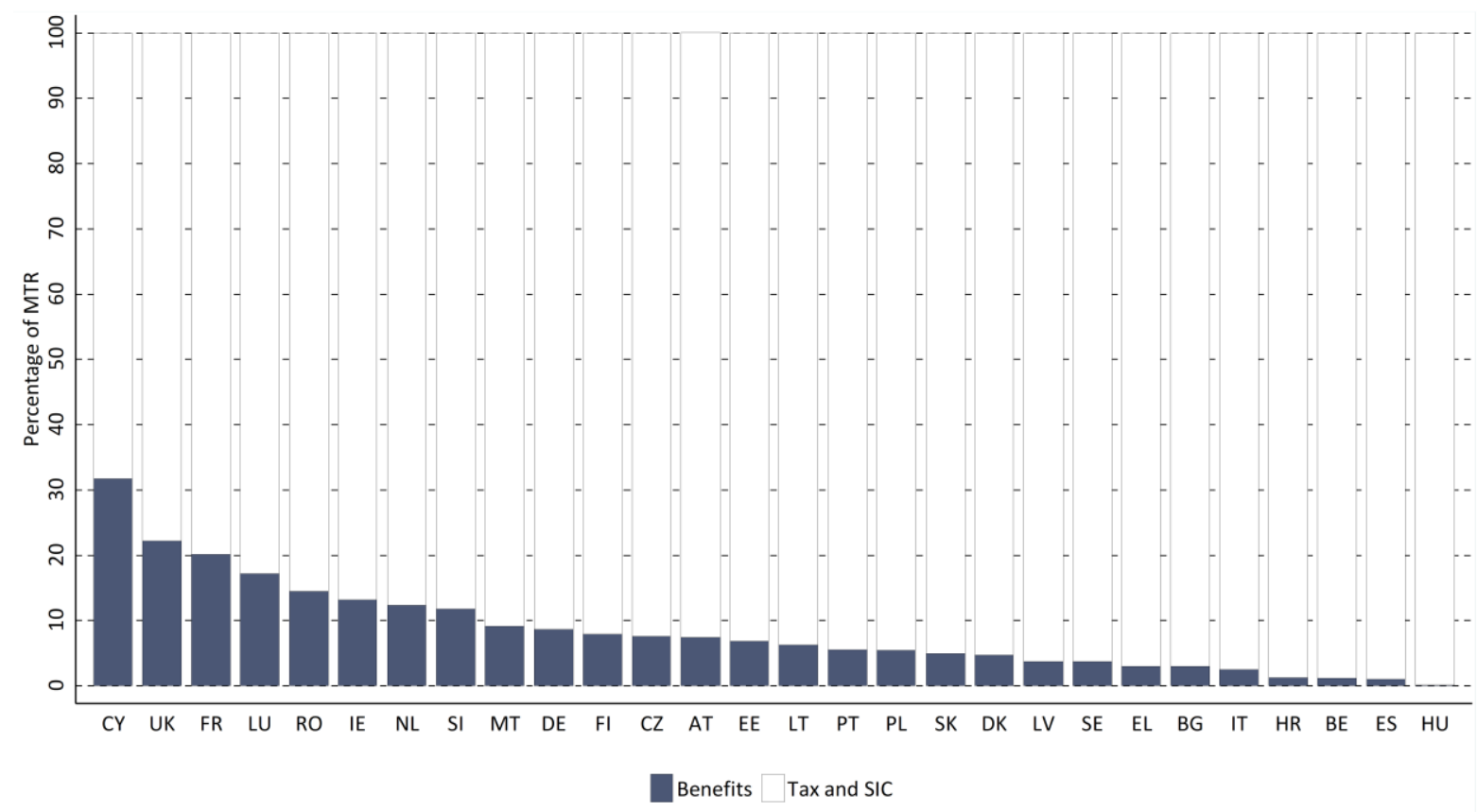




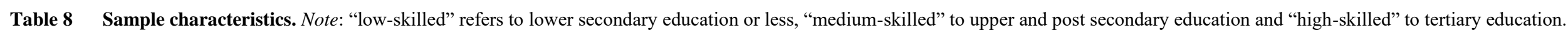
"Self-employed" are defined as those with self-employment income, who do not have employment income."Part-time" is defined as working less than 30 hours per week. "Main earner" is the individual with the highest earnings in the household. High risk of unemployment (UE) refers to the 10\% of the sample with the highest risk. Source: own calculations using EUROMOD version H1.0

\begin{tabular}{|c|c|c|c|c|c|c|c|c|c|c|c|c|c|c|c|c|c|c|c|c|c|c|c|c|c|c|c|c|}
\hline & BE & BG & CZ & DK & DE & EE & IE & EL & ES & FR & HR & IT & CY & LV & LT & $\mathbf{L U}$ & HU & MT & NL & AT & PL & PT & RO & SI & SK & FI & SE & UK \\
\hline N. of observations & 5317 & 4617 & 7470 & 6452 & 10881 & 6264 & 4685 & 10599 & 11718 & 10258 & 5391 & 15926 & 4699 & 5652 & 4367 & 3915 & 7181 & 4387 & 10903 & 5701 & 11085 & 7910 & 6640 & 10611 & 6798 & 11892 & 6202 & 16654 \\
\hline Population $(1,000)$ & 4336 & 3027 & 4649 & 2400 & 34800 & 609 & 1709 & 3487 & 17768 & 25273 & 1447 & 22236 & 365 & 871 & 1241 & 230 & 4098 & 173 & 7309 & 3779 & $13397 \mid$ & 4027 & 8004 & 827 & 2389 & 2300 & 4482 & 25794 \\
\hline$\%$ female & 46.3 & 47.1 & 44.5 & 48.0 & 48.8 & 49.9 & 47.2 & 41.6 & 45.2 & 48.9 & 44.8 & 42.1 & 49.3 & 50.4 & 48.3 & 46.8 & 46.7 & 39.3 & 46.3 & 45.1 & 46.0 & 49.9 & 41.3 & 44.3 & 45.7 & 49.7 & 48.4 & 47.5 \\
\hline$\%$ age $(<30)$ & 16.8 & 16.1 & 15.9 & 14.7 & 15.3 & 20.9 & 15.7 & 12.2 & 11.8 & 19.3 & 19.2 & 12.1 & 22.8 & 19.3 & 19.4 & 20.1 & 17.4 & 26.9 & 18.8 & 21.7 & 18.9 & 15.6 & 15.4 & 13.7 & 19.4 & 18.1 & 18.5 & 22.5 \\
\hline$\%$ age $(30-50)$ & 59.3 & 56.7 & 59.5 & 55.6 & 55.6 & 51.1 & 58.8 & 65.3 & 64.4 & 58.0 & 57.6 & 60.7 & 56.5 & 52.2 & 51.4 & 62.1 & 54.7 & 51.5 & 53.4 & 53.4 & 57.8 & 61.3 & 63.6 & 65.6 & 57.9 & 52.0 & 52.8 & 52.2 \\
\hline$\%$ age $(50+)$ & 23.9 & 27.3 & 24.6 & 29.6 & 29.1 & 28.0 & 25.5 & 22.6 & 23.8 & 22.8 & 23.3 & 27.2 & 20.7 & 28.6 & 29.1 & 17.8 & 27.9 & 21.6 & 27.8 & 24.8 & 23.3 & 23.1 & 21.1 & 20.7 & 22.6 & 29.9 & 28.7 & 25.3 \\
\hline$\%$ low-skilled & 12.4 & 13.2 & 3.3 & 15.3 & 6.3 & 11.3 & 15.3 & 20.8 & 33.5 & 12.7 & 10.0 & 29.5 & 15.8 & 9.2 & 4.8 & 29.7 & 11.8 & 42.4 & 18.1 & 11.5 & 5.6 & 49.8 & 27.6 & 9.3 & 2.5 & 11.1 & 10.2 & 45.5 \\
\hline$\%$ medium-skilled & 37.9 & 58.0 & 74.5 & 44.7 & 55.2 & 46.8 & 29.4 & 42.3 & 23.9 & 47.7 & 66.4 & 46.0 & 42.0 & 55.8 & 54.1 & 39.0 & 59.6 & 29.3 & 41.1 & 55.2 & 61.1 & 26.2 & 51.2 & 56.9 & 72.3 & 44.8 & 46.3 & 25.8 \\
\hline$\%$ high-skilled & 49.7 & 28.8 & 22.2 & 40.0 & 38.4 & 41.9 & 55.3 & 37.0 & 42.6 & 39.6 & 23.6 & 24.5 & 42.2 & 35.0 & 41.1 & 31.2 & 28.6 & 28.3 & 40.9 & 33.3 & 33.3 & 24.1 & 21.1 & 33.8 & 25.2 & 44.1 & 43.5 & 28.6 \\
\hline$\%$ employee & 91.1 & 91.5 & 84.0 & 95.9 & 94.7 & 99.0 & 88.1 & 69.1 & 90.1 & 94.9 & 90.5 & 77.2 & 89.8 & 96.2 & 94.9 & 95.6 & 92.8 & 91.0 & 91.5 & 90.9 & 87.7 & 93.3 & 77.7 & 90.8 & 87.4 & 95.1 & 98.0 & 88.1 \\
\hline$\%$ self-employed & 8.9 & 8.5 & 16.0 & 4.1 & 5.3 & 1.0 & 11.9 & 30.9 & 9.9 & 5.1 & 9.5 & 19.0 & 10.2 & 3.8 & 5.1 & 4.4 & 7.2 & 9.0 & 8.5 & 9.1 & 12.3 & 6.7 & 22.3 & 9.2 & 12.6 & 4.9 & 2.0 & 11.9 \\
\hline$\%$ main earner & 64.9 & 60.4 & 60.6 & 65.3 & 67.4 & 62.2 & 60.1 & 69.7 & 65.9 & 64.9 & 61.0 & 67.9 & 61.4 & 60.3 & 61.7 & 63.0 & 62.9 & 58.4 & 63.8 & 62.5 & 59.3 & 62.4 & 61.5 & 60.7 & 54.0 & 65.5 & 64.0 & 62.0 \\
\hline$\%$ secondary earner & 35.1 & 39.6 & 39.4 & 34.7 & 32.6 & 37.8 & 39.9 & 30.3 & 34.1 & 35.1 & 39.0 & 32.1 & 38.6 & 39.7 & 38.3 & 37.0 & 37.1 & 41.6 & 36.2 & 37.5 & 40.7 & 37.6 & 38.5 & 39.3 & 46.0 & 34.5 & 36.0 & 38.0 \\
\hline$\%$ part-time & 15.1 & 5.9 & 4.6 & 10.6 & 17.8 & 8.1 & 27.3 & 15.5 & 18.8 & 13.3 & 5.0 & 15.6 & 15.9 & 9.6 & 7.0 & 17.3 & 8.1 & 8.2 & 30.2 & 18.3 & 7.1 & 6.5 & 3.9 & 7.3 & 3.4 & 11.7 & 8.2 & 19.6 \\
\hline $\begin{array}{l}\text { average working } \\
\text { hours }\end{array}$ & 38.2 & 41.0 & 41.8 & 38.1 & 37.8 & 40.3 & 35.1 & 41.6 & 38.1 & 38.0 & 41.1 & 37.4 & 37.7 & 39.6 & 39.4 & 38.3 & 39.3 & 39.9 & 33.1 & 38.3 & 41.8 & 41.4 & 40.7 & 40.3 & 41.2 & 39.5 & 39.7 & 36.5 \\
\hline poverty risk & 2.8 & 9.0 & 5.2 & 4.0 & 5.9 & 9.7 & 3.3 & 9.4 & 14.1 & 3.5 & 6.7 & 10.9 & 10.1 & 10.5 & 9.6 & 8.1 & 12.6 & 4.2 & 6.1 & 7.2 & 8.2 & 8.7 & 15.7 & 8.2 & 4.7 & 3.8 & 6.2 & 3.5 \\
\hline high risk of UE & 10.0 & 10.0 & 10.0 & 10.0 & 10.0 & 10.0 & 9.9 & 10.0 & 10.0 & 10.0 & 10.0 & 10.0 & 10.0 & 10.0 & 10.0 & 10.0 & 10.0 & 10.0 & 10.0 & 10.0 & 10.0 & 10.0 & 10.0 & 10.0 & 10.0 & 10.0 & 10.0 & 9.7 \\
\hline
\end{tabular}




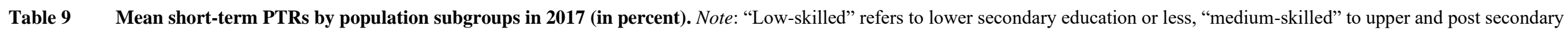
education and "high-skilled" to tertiary education. "Self-employed" are defined as those with self-employment income, who do not have employment income."Part-time" is defined as working less than 30 hours per week. "Main earner" is the individual with the highest earnings in the household. High risk of unemployment (UE) refers to the 10\% of the sample with the highest risk. Source: own calculations using EUROMOD version H1.0

\begin{tabular}{|c|c|c|c|c|c|c|c|c|c|c|c|c|c|c|c|c|c|c|c|c|c|c|c|c|c|c|c|c|}
\hline & BE & BG & CZ & DK & DE & EE & IE & EL & ES & FR & HR & IT & $\mathrm{CY}$ & LV & LT & LU & HU & MT & NL & AT & PL & PT & RO & SI & SK & FI & SE & UK \\
\hline All & 74.3 & 61.8 & 49.4 & 75.2 & 70.8 & 51.4 & 47.5 & 61.7 & 49.8 & 77.3 & 53.9 & 56.6 & 43.4 & 53.2 & 43.3 & 82.8 & 51.1 & 38.8 & 64.0 & 68.3 & 46.4 & 74.0 & 44.4 & 59.0 & 48.6 & 70.6 & 66.9 & 45.0 \\
\hline Male & 72.7 & 60.7 & 48.8 & 72.8 & 72.5 & 51.1 & 46.6 & 60.7 & 49.5 & 76.9 & 53.2 & 54.3 & 44.1 & 53.3 & 43.2 & 82.0 & 51.1 & 39.2 & 65.9 & 67.3 & 46.1 & 72.1 & 45.3 & 58.8 & 49.7 & 70.6 & 66.0 & 44.9 \\
\hline female & 76.2 & 63.0 & 50.0 & 77.9 & 69.0 & 51.7 & 48.6 & 63.2 & 50.3 & 77.7 & 54.8 & 59.8 & 42.7 & 53.0 & 43.3 & 83.7 & 51.1 & 38.3 & 61.8 & 69.5 & 46.8 & 76.0 & 43.2 & 59.3 & 47.3 & 70.7 & 67.8 & 45.1 \\
\hline age $(<30)$ & 77.4 & 49.5 & 43.8 & 68.2 & 68.8 & 46.6 & 42.8 & 70.3 & 51.7 & 75.8 & 42.1 & 50.7 & 38.5 & 47.7 & 42.5 & 72.6 & 53.8 & 48.5 & 51.1 & 68.1 & 41.8 & 64.5 & 42.7 & 42.4 & 43.0 & 70.5 & 67.3 & 40.2 \\
\hline age (30-50) & 73.8 & 64.4 & 47.6 & 76.1 & 71.6 & 53.8 & 47.6 & 61.5 & 49.9 & 77.5 & 56.8 & 56.2 & 45.5 & 54.5 & 42.8 & 85.6 & 47.2 & 35.2 & 66.5 & 69.9 & 45.9 & 76.5 & 44.6 & 60.0 & 50.2 & 70.9 & 66.9 & 48.0 \\
\hline age (50+) & 73.6 & 63.5 & 57.3 & 77.1 & 70.4 & 50.6 & 50.3 & 57.8 & 48.9 & 78.0 & 56.5 & 60.1 & 43.1 & 54.5 & 44.6 & 84.5 & 57.0 & 35.5 & 67.8 & 65.1 & 51.4 & 73.9 & 45.0 & 67.3 & 49.2 & 70.2 & 66.6 & 43.0 \\
\hline low-skilled & 77.6 & 59.4 & 49.7 & 72.8 & 69.2 & 51.0 & 49.5 & 65.1 & 53.6 & 78.9 & 59.8 & 54.5 & 49.6 & 50.3 & 48.8 & 84.5 & 53.2 & 41.4 & 64.7 & 74.2 & 51.9 & 75.5 & 41.1 & 64.6 & 48.8 & 71.7 & 70.9 & 46.3 \\
\hline medium-skilled & 75.3 & 62.8 & 50.0 & 77.5 & 71.0 & 52.7 & 47.9 & 63.2 & 50.6 & 77.2 & 54.7 & 57.4 & 45.0 & 52.5 & 45.4 & 83.0 & 52.0 & 39.0 & 64.1 & 69.2 & 48.0 & 73.3 & 46.0 & 59.9 & 48.8 & 70.7 & 67.6 & 43.9 \\
\hline high-skilled & 72.8 & 60.9 & 47.1 & 73.7 & 70.8 & 50.0 & 46.8 & 58.1 & 46.5 & 76.7 & 49.1 & 57.6 & 39.5 & 55.0 & 39.8 & 81.0 & 48.4 & 34.9 & 63.5 & 64.7 & 42.6 & 71.6 & 45.0 & 56.1 & 48.0 & 70.3 & 65.2 & 43.9 \\
\hline employee & 76.5 & 64.2 & 47.2 & 75.1 & 72.4 & 51.2 & 47.2 & 63.1 & 48.7 & 78.9 & 53.8 & 64.2 & 44.0 & 54.2 & 43.7 & 82.3 & 48.3 & 38.8 & 68.1 & 70.0 & 45.4 & 76.1 & 50.1 & 57.4 & 46.3 & 70.6 & 66.3 & 46.2 \\
\hline self-employed & 51.9 & 35.9 & 60.9 & 78.3 & 41.9 & 66.8 & 50.3 & 58.6 & 60.4 & 47.2 & 54.9 & 35.4 & 38.2 & 27.9 & 35.0 & 94.7 & 87.6 & 39.4 & 19.7 & 51.6 & 53.4 & 45.5 & 24.8 & 74.8 & 64.8 & 71.4 & 94.8 & 36.0 \\
\hline main earner & 74.4 & 64.3 & 49.7 & 73.1 & 72.2 & 52.9 & 50.1 & 60.0 & 50.7 & 77.3 & 54.5 & 56.8 & 46.5 & 56.1 & 43.0 & 85.1 & 49.5 & 36.8 & 68.4 & 69.7 & 45.7 & 75.6 & 46.7 & 59.1 & 50.6 & 71.6 & 65.7 & 48.1 \\
\hline secondary earner & 74.2 & 58.0 & 48.9 & 79.2 & 67.9 & 48.8 & 43.6 & 65.7 & 48.3 & 77.1 & 52.9 & 56.2 & 38.4 & 48.8 & 43.7 & 79.0 & 53.7 & 41.8 & 56.3 & 66.1 & 47.5 & 71.4 & 40.8 & 59.0 & 46.3 & 68.8 & 69.0 & 39.8 \\
\hline part-timer & 80.2 & 54.3 & 51.3 & 80.1 & 61.4 & 50.7 & 51.1 & 81.2 & 57.6 & 77.3 & 51.2 & 46.5 & 40.7 & 43.6 & 47.7 & 81.4 & 63.6 & 48.7 & 62.2 & 73.1 & 49.3 & 68.6 & 34.6 & 63.6 & 47.5 & 72.8 & 63.0 & 49.1 \\
\hline earnings Q1 & 71.4 & 47.4 & 52.7 & 80.5 & 57.8 & 56.2 & 54.6 & 87.1 & 73.1 & 72.0 & 46.2 & 39.1 & 39.9 & 38.8 & 54.6 & 73.3 & 64.0 & 57.0 & 53.0 & 70.9 & 55.1 & 63.4 & 29.4 & 64.9 & 49.1 & 70.1 & 76.0 & 50.1 \\
\hline earnings Q2 & 75.8 & 63.2 & 49.7 & 81.0 & 70.6 & 50.7 & 46.7 & 62.7 & 55.1 & 79.9 & 58.5 & 52.9 & 51.2 & 53.0 & 44.0 & 86.2 & 51.2 & 41.0 & 57.1 & 72.4 & 51.4 & 73.8 & 49.5 & 57.4 & 47.4 & 70.6 & 72.4 & 43.9 \\
\hline earnings Q3 & 79.5 & 65.1 & 49.4 & 76.2 & 73.4 & 49.8 & 43.8 & 56.7 & 46.5 & 78.2 & 60.0 & 60.6 & 45.5 & 55.4 & 44.6 & 86.8 & 49.8 & 36.7 & 63.1 & 67.5 & 46.8 & 76.4 & 49.8 & 60.9 & 48.3 & 71.5 & 66.9 & 44.3 \\
\hline earnings Q4 & 75.3 & 65.1 & 49.6 & 72.2 & 75.3 & 51.6 & 45.0 & 53.4 & 44.2 & 77.9 & 53.9 & 63.8 & 40.4 & 57.4 & 41.9 & 88.3 & 48.4 & 32.7 & 70.9 & 67.9 & 42.7 & 82.8 & 48.1 & 58.6 & 48.8 & 71.4 & 61.4 & 43.4 \\
\hline earnings Q5 & 69.3 & 62.6 & 45.9 & 66.8 & 74.6 & 49.6 & 48.6 & 50.4 & 40.3 & 76.7 & 48.6 & 60.3 & 39.4 & 57.6 & 34.6 & 78.9 & 45.0 & 30.4 & 72.9 & 63.6 & 37.6 & 72.7 & 44.3 & 54.8 & 49.4 & 69.3 & 59.4 & 43.7 \\
\hline poverty risk & 86.5 & 62.2 & 69.1 & 87.3 & 61.6 & 72.1 & 76.3 & 86.8 & 78.9 & 69.1 & 58.3 & 37.6 & 64.5 & 54.8 & 62.8 & 93.6 & 65.6 & 64.1 & 59.8 & 93.7 & 61.9 & 80.3 & 39.4 & 72.3 & 72.3 & 81.8 & 83.9 & 66.2 \\
\hline high risk of UE & 80.5 & 55.7 & 50.1 & 68.2 & 69.1 & 45.6 & 46.8 & 66.6 & 54.6 & 75.2 & 44.4 & 49.1 & 36.8 & 50.3 & 46.0 & 79.7 & 52.3 & 44.2 & 62.0 & 73.7 & 45.4 & 72.2 & 44.2 & 52.8 & 43.3 & 71.6 & 71.3 & 49.3 \\
\hline
\end{tabular}




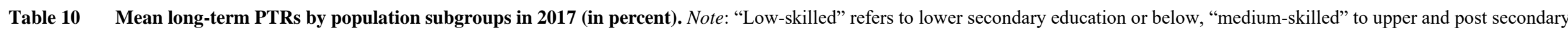
education and "high-skilled" to tertiary education. "Self-employed" are defined as those with self-employment income, who do not have employment income."Part-time" is defined as working less than 30 hours per week. "Main earner" is the individual with the highest earnings in the household. High risk of unemployment (UE) refers to the 10\% of the sample with the highest risk. Source: own calculations using EUROMOD version H1.0

\begin{tabular}{|c|c|c|c|c|c|c|c|c|c|c|c|c|c|c|c|c|c|c|c|c|c|c|c|c|c|c|c|c|}
\hline & BE & BG & CZ & DK & DE & EE & IE & EL & ES & FR & HR & IT & $\mathrm{CY}$ & LV & LT & LU & $\mathrm{HU}$ & MT & NL & AT & PL & PT & RO & SI & SK & FI & SE & UK \\
\hline all & 48.1 & 25.3 & 34.8 & 56.8 & 43.5 & 34.5 & 44.2 & 45.8 & 32.1 & 39.9 & 28.7 & 24.1 & 30.7 & 30.2 & 24.8 & 43.6 & 41.5 & 34.9 & 32.7 & 47.8 & 33.9 & 42.3 & 29.1 & 39.6 & 37.8 & 56.0 & 30.7 & 35.7 \\
\hline male & 8.9 & 25.4 & 34.9 & 57.7 & 46.0 & 34.4 & 46.7 & 47.8 & 33.3 & 41.6 & 28.4 & 24.6 & 33.2 & 30.2 & 26.1 & 45.7 & 41.6 & 36.2 & 36.5 & 51.3 & 33.7 & 43.1 & 31.0 & 40.5 & 39.7 & 56.0 & 32.8 & 39.3 \\
\hline female & 47.3 & 25.2 & 34.8 & 55.8 & 41.0 & 34.7 & 41.3 & 43.0 & 30.8 & 38.2 & 29.1 & 23.5 & 28.1 & 30.3 & 23.4 & 41.3 & 41.3 & 32.8 & 28.3 & 43.5 & 34.1 & 41.5 & 26.5 & 38.6 & 35.6 & 56.0 & 28.4 & 31.8 \\
\hline age $(<30)$ & 50.6 & 24.7 & 32.5 & 65.8 & 46.8 & 35.0 & 47.2 & 50.1 & 23.7 & 36.8 & 27.8 & 19.7 & 25.0 & 28.9 & 27.8 & 33.1 & 50.5 & 45.6 & 37.4 & 53.9 & 30.6 & 35.4 & 34.8 & 36.8 & 36.5 & 59.2 & 27.4 & 34.1 \\
\hline age (30-50) & 47.2 & 26.2 & 35.8 & 57.2 & 43.3 & 35.0 & 43.5 & 44.5 & 32.9 & 41.0 & 29.1 & 23.6 & 32.2 & 30.3 & 25.2 & 46.0 & 39.1 & 30.6 & 30.1 & 47.4 & 36.0 & 43.8 & 28.0 & 40.8 & 38.9 & 55.6 & 31.5 & 37.8 \\
\hline age $(50+)$ & 48.9 & 23.9 & 34.0 & 51.6 & 42.4 & 33.4 & 43.9 & 47.3 & 34.4 & 39.8 & 28.7 & 27.3 & 32.7 & 31.0 & 22.0 & 47.2 & 40.6 & 31.7 & 34.5 & 43.3 & 31.4 & 43.1 & 28.1 & 37.9 & 36.3 & 54.7 & 31.3 & 32.9 \\
\hline low-skilled & 48.3 & 33.1 & 34.8 & 59.5 & 48.1 & 37.7 & 45.7 & 52.5 & 33.8 & 41.3 & 26.9 & 19.7 & 41.3 & 31.8 & 34.8 & 46.4 & 43.3 & 36.7 & 36.5 & 52.1 & 35.3 & 46.3 & 30.1 & 39.6 & 37.5 & 59.8 & 32.9 & 35.9 \\
\hline medium-skilled & 47.0 & 24.7 & 35.0 & 57.9 & 44.1 & 36.5 & 44.8 & 46.1 & 31.9 & 40.9 & 28.0 & 24.0 & 31.8 & 30.3 & 24.5 & 41.1 & 41.7 & 35.1 & 33.2 & 47.2 & 34.1 & 39.0 & 28.2 & 39.5 & 37.9 & 57.2 & 30.1 & 35.2 \\
\hline high-skilled & 49.0 & 23.0 & 34.1 & 54.5 & 42.0 & 31.5 & 43.4 & 41.8 & 31.0 & 38.2 & 31.6 & 29.7 & 25.6 & 29.8 & 24.0 & 44.2 & 40.3 & 31.9 & 30.5 & 47.2 & 33.3 & 37.7 & 30.0 & 39.9 & 37.6 & 53.8 & 30.8 & 36.0 \\
\hline employee & 47.8 & 24.3 & 32.3 & 56.7 & 43.6 & 34.2 & 43.3 & 40.1 & 29.0 & 39.5 & 28.2 & 22.2 & 29.8 & 30.3 & 24.2 & 43.2 & 39.0 & 34.4 & 33.9 & 47.4 & 34.0 & 42.1 & 30.3 & 39.0 & 33.9 & 55.2 & 30.2 & 35.7 \\
\hline self-employed & 51.9 & 35.9 & 48.2 & 59.4 & 41.9 & 66.8 & 50.3 & 58.6 & 60.4 & 47.2 & 33.3 & 35.3 & 38.2 & 27.9 & 35.0 & 51.8 & 72.8 & 39.4 & 19.7 & 51.6 & 33.0 & 45.5 & 24.8 & 45.7 & 64.8 & 70.7 & 55.5 & 36.0 \\
\hline main earner & 50.4 & 26.6 & 36.4 & 58.3 & 45.5 & 36.1 & 47.8 & 47.5 & 34.8 & 42.1 & 29.0 & 23.9 & 36.9 & 33.4 & 28.0 & 50.6 & 39.9 & 34.0 & 38.0 & 54.2 & 34.3 & 49.8 & 31.6 & 42.2 & 41.2 & 57.6 & 34.8 & 42.5 \\
\hline secondary earner & 44.0 & 23.3 & 32.3 & 53.9 & 39.4 & 32.0 & 38.6 & 41.9 & 26.9 & 35.9 & 28.3 & 24.6 & 20.7 & 25.4 & 19.6 & 31.7 & 44.2 & 36.2 & 23.3 & 37.1 & 33.3 & 30.0 & 25.2 & 35.7 & 33.9 & 53.0 & 23.5 & 24.7 \\
\hline part-timer & 46.7 & 36.2 & 41.6 & 66.2 & 36.0 & 38.4 & 44.1 & 52.5 & 34.7 & 36.7 & 30.6 & 13.7 & 31.2 & 29.7 & 27.8 & 39.8 & 53.3 & 37.5 & 30.2 & 42.7 & 34.3 & 46.7 & 31.8 & 42.8 & 39.8 & 65.2 & 28.6 & 30.5 \\
\hline earnings Q1 & 48.4 & 33.2 & 41.9 & 74.4 & 39.3 & 46.0 & 50.3 & 63.3 & 48.8 & 34.2 & 29.3 & 16.4 & 32.9 & 30.3 & 31.9 & 36.9 & 54.7 & 48.8 & 38.3 & 55.2 & 33.8 & 47.0 & 27.5 & 43.2 & 42.5 & 65.8 & 28.5 & 31.6 \\
\hline earnings Q2 & 45.3 & 25.2 & 33.4 & 56.7 & 46.6 & 38.5 & 42.0 & 43.4 & 33.4 & 42.1 & 26.6 & 16.1 & 37.0 & 30.4 & 20.5 & 45.8 & 41.5 & 36.9 & 28.6 & 46.9 & 35.4 & 45.9 & 27.6 & 39.0 & 35.1 & 57.1 & 29.9 & 33.4 \\
\hline earnings Q3 & 47.6 & 24.6 & 33.0 & 53.7 & 44.0 & 33.1 & 39.5 & 40.3 & 27.0 & 42.2 & 26.5 & 21.0 & 30.7 & 30.0 & 23.2 & 46.3 & 38.7 & 33.5 & 29.3 & 47.0 & 34.7 & 39.6 & 29.5 & 38.5 & 37.0 & 53.6 & 28.9 & 36.7 \\
\hline earnings Q4 & 48.4 & 23.3 & 33.1 & 50.4 & 43.9 & 30.3 & 42.6 & 40.5 & 27.5 & 40.1 & 28.7 & 27.2 & 26.0 & 30.2 & 24.8 & 42.9 & 37.7 & 29.6 & 31.9 & 45.9 & 33.5 & 38.2 & 30.2 & 37.9 & 37.1 & 52.6 & 29.0 & 37.0 \\
\hline earnings Q5 & 51.0 & 23.4 & 33.4 & 50.6 & 43.2 & 27.2 & 47.2 & 43.0 & 30.8 & 39.2 & 32.7 & 36.4 & 27.4 & 30.3 & 25.6 & 46.0 & 37.8 & 28.4 & 36.6 & 45.9 & 32.2 & 41.5 & 30.5 & 40.5 & 37.9 & 53.0 & 36.8 & 39.5 \\
\hline poverty risk & 77.0 & 41.8 & 63.2 & 96.4 & 51.7 & 65.4 & 82.8 & 72.3 & 61.7 & 38.5 & 35.8 & 13.2 & 61.6 & 47.5 & 45.4 & 75.0 & 57.9 & 60.4 & 44.6 & 93.5 & 37.4 & 83.2 & 35.7 & 65.0 & 71.8 & 80.3 & 46.7 & 59.7 \\
\hline high risk of UE & 60.1 & 33.7 & 41.1 & 68.2 & 49.8 & 36.7 & 53.6 & 50.4 & 34.9 & 37.2 & 29.7 & 18.4 & 23.8 & 37.7 & 36.8 & 48.2 & 47.3 & 36.3 & 48.8 & 53.3 & 32.6 & 56.7 & 34.8 & 43.5 & 37.6 & 63.6 & 30.6 & 37.8 \\
\hline
\end{tabular}


Table 11 Mean METRs by population subgroups in 2017 (in percent). Note: "Low-skilled" refers to lower secondary education or below, "medium-skilled" to upper and post secondary education and "high-skilled" to tertiary education. "Self-employed" are defined as those with self-employment income, who do not have employment income."Part-time" is defined as working less than 30 hours per week. "Main earner" is the individual with the highest earnings in the household. High risk of unemployment (UE) refers to the 10\% of the sample with the highest risk. "." omitted due to data difficulties. Source: own calculations using EUROMOD version H1.0

\begin{tabular}{|c|c|c|c|c|c|c|c|c|c|c|c|c|c|c|c|c|c|c|c|c|c|c|c|c|c|c|c|c|}
\hline & BE & BG & CZ & DK & DE & EE & IE & EL & ES & FR & HR & IT & CY & LV & LT & LU & HU & MT & NL & AT & PL & PT & RO & SI & SK & FI & SE & UK \\
\hline all & 54.2 & 21.9 & 28.5 & 46.0 & 45.3 & 23.1 & 41.2 & 32.6 & 23.5 & 39.5 & 28.1 & 40.2 & 23.4 & 31.1 & 26.6 & 43.7 & 29.1 & 25.8 & 41.3 & 42.3 & 29.5 & 31.0 & 33.0 & 39.7 & 32.8 & 45.6 & 38.7 & 38.9 \\
\hline male & 54.9 & 21.8 & 29.3 & 47.1 & 45.4 & 23.2 & 42.5 & 35.0 & 24.2 & 40.1 & 28.0 & 41.8 & 23.4 & 31.0 & 26.9 & 43.5 & 28.1 & 26.4 & 46.0 & 44.8 & 28.4 & 31.3 & 33.5 & 39.8 & 33.5 & 47.2 & 41.5 & 40.2 \\
\hline female & 53.5 & 22.0 & 27.6 & 44.7 & 45.2 & 23.1 & 39.6 & 29.3 & 22.6 & 38.8 & 28.1 & 38.0 & 23.4 & 31.3 & 26.3 & 44.0 & 30.2 & 24.9 & 35.9 & 39.2 & 30.6 & 30.6 & 32.3 & 39.5 & 31.9 & 44.1 & 35.8 & 37.5 \\
\hline age $(<30)$ & 52.9 & 22.7 & 26.6 & 43.1 & 43.6 & 23.4 & 26.8 & 23.6 & 15.9 & 39.4 & 26.8 & 32.5 & 16.9 & 31.2 & 27.2 & 37.6 & 31.0 & 27.2 & 37.0 & 39.2 & 30.0 & 24.9 & 37.8 & 35.8 & 30.9 & 43.9 & 29.8 & 33.7 \\
\hline age (30-50) & 54.6 & 22.0 & 29.1 & 46.7 & 45.7 & 23.3 & 44.4 & 33.5 & 23.8 & 39.1 & 27.9 & 40.9 & 25.3 & 31.0 & 25.8 & 44.8 & 27.3 & 25.5 & 42.3 & 42.7 & 30.0 & 32.3 & 31.8 & 40.4 & 33.6 & 46.1 & 40.5 & 42.1 \\
\hline age $(50+)$ & 54.3 & 21.1 & 28.3 & 46.2 & 45.6 & 22.5 & 42.4 & 35.0 & 26.4 & 40.5 & 29.6 & 42.0 & 25.3 & 31.2 & 27.7 & 46.9 & 31.4 & 24.9 & 42.4 & 44.0 & 27.6 & 31.6 & 33.1 & 39.9 & 32.3 & 45.8 & 41.1 & 36.9 \\
\hline low-skilled & 53.0 & 26.2 & 29.2 & 44.4 & 47.9 & 23.1 & 39.2 & 27.0 & 17.9 & 42.5 & 22.4 & 36.5 & 28.3 & 32.2 & 28.5 & 41.8 & 30.4 & 24.9 & 38.4 & 40.2 & 28.6 & 27.0 & 36.4 & 40.0 & 32.4 & 43.4 & 36.8 & 39.4 \\
\hline medium-skilled & 53.6 & 21.8 & 28.2 & 44.8 & 45.6 & 23.3 & 35.3 & 31.6 & 23.3 & 39.8 & 26.7 & 40.6 & 22.2 & 31.0 & 26.7 & 42.8 & 24.1 & 26.5 & 40.1 & 41.5 & 29.1 & 31.5 & 31.7 & 39.1 & 32.8 & 44.2 & 37.2 & 37.8 \\
\hline high-skilled & 55.0 & 20.1 & 29.4 & 47.9 & 44.6 & 22.9 & 44.8 & 37.0 & 28.0 & 38.1 & 34.3 & 43.8 & 22.8 & 31.1 & 26.3 & 46.9 & 38.9 & 26.5 & 43.9 & 44.2 & 30.3 & 38.6 & 31.7 & 40.7 & 32.6 & 47.7 & 40.7 & 39.2 \\
\hline employee & 54.7 & 21.1 & 29.2 & 46.1 & 45.4 & 23.0 & 41.4 & 31.4 & 24.3 & 39.0 & 30.0 & 41.3 & 23.2 & 31.5 & 26.8 & 43.4 & 29.6 & 25.8 & 42.3 & 41.7 & 31.9 & 31.8 & 32.1 & 41.2 & 30.6 & 45.6 & 38.2 & 39.1 \\
\hline self-employed & 49.4 & 30.8 & 25.0 & 43.6 & 43.9 & 33.8 & 39.2 & 35.5 & 16.3 & 48.0 & 9.5 & 42.3 & 24.9 & 20.8 & 23.9 & 51.2 & 22.6 & 26.1 & 31.3 & 48.4 & 11.9 & 19.7 & 36.1 & 24.4 & 47.6 & 46.9 & 63.1 & 37.4 \\
\hline main earner & 55.1 & 21.9 & 30.8 & 47.9 & 46.8 & 24.2 & 45.7 & 35.8 & 24.8 & 41.5 & 28.5 & 42.5 & 26.3 & 31.6 & 27.6 & 46.7 & 27.3 & 27.2 & 46.8 & 46.5 & 29.3 & 32.2 & 32.7 & 43.1 & 34.4 & 48.2 & 42.6 & 43.9 \\
\hline secondary earner & 52.6 & 21.8 & 25.1 & 42.4 & 42.2 & 21.4 & 34.2 & 25.3 & 21.0 & 35.7 & 27.4 & 35.2 & 18.7 & 30.3 & 25.1 & 38.7 & 32.2 & 23.9 & 31.8 & 35.2 & 29.6 & 29.0 & 33.5 & 34.4 & 30.8 & 40.7 & 31.9 & 30.8 \\
\hline part-timer & 48.6 & 30.4 & 14.9 & 41.7 & 43.7 & 22.7 & 32.0 & 21.6 & 12.9 & 42.5 & 19.4 & 21.1 & 25.9 & 30.3 & 25.5 & 45.0 & . & 20.0 & 31.5 & 35.5 & 32.5 & 21.1 & 46.1 & 36.1 & 27.3 & 42.6 & 31.5 & 35.5 \\
\hline earnings Q1 & 40.4 & 27.1 & 14.9 & 40.9 & 42.5 & 25.4 & 23.3 & 14.9 & 7.0 & 43.0 & 17.1 & 15.7 & 36.7 & 29.4 & 22.4 & 42.1 & 18.4 & 19.2 & 30.7 & 33.6 & 27.3 & 20.1 & 40.2 & 28.8 & 32.3 & 37.7 & 30.2 & 32.5 \\
\hline earnings Q2 & 60.6 & 21.5 & 31.8 & 43.1 & 46.7 & 22.6 & 33.7 & 21.5 & 10.1 & 43.0 & 20.1 & 32.4 & 20.1 & 30.9 & 25.2 & 41.4 & 19.1 & 24.7 & 23.9 & 40.1 & 31.5 & 23.0 & 28.7 & 43.5 & 33.3 & 41.7 & 31.5 & 43.3 \\
\hline earnings Q3 & 55.0 & 21.6 & 30.9 & 44.5 & 45.5 & 22.6 & 41.8 & 38.1 & 24.5 & 37.1 & 30.5 & 41.3 & 10.7 & 32.2 & 30.9 & 40.4 & 25.3 & 30.5 & 47.9 & 43.6 & 29.5 & 28.3 & 32.4 & 38.6 & 31.7 & 46.0 & 31.6 & 39.2 \\
\hline earnings Q4 & 55.1 & 21.2 & 31.5 & 45.3 & 47.1 & 22.6 & 50.0 & 39.9 & 30.0 & 35.6 & 30.9 & 52.6 & 19.8 & 31.9 & 29.2 & 47.0 & 39.9 & 26.8 & 50.1 & 45.9 & 29.0 & 37.5 & 33.2 & 40.7 & 32.3 & 48.6 & 42.1 & 36.3 \\
\hline earnings Q5 & 58.4 & 20.1 & 32.1 & 55.5 & 44.4 & 22.8 & 54.3 & 47.6 & 37.6 & 39.8 & 38.5 & 49.7 & 33.1 & 30.7 & 24.2 & 47.7 & 39.8 & 26.7 & 51.0 & 46.1 & 29.7 & 44.7 & 30.8 & 44.2 & 34.2 & 52.4 & 56.6 & 42.9 \\
\hline poverty risk & 42.0 & 29.4 & 21.7 & 39.2 & 55.3 & 32.9 & 25.0 & 24.2 & 4.4 & 47.3 & 20.0 & 20.8 & 41.0 & 32.8 & 29.6 & 69.3 & . & 27.2 & 39.4 & 61.5 & 26.1 & 27.2 & 44.2 & 52.9 & 47.2 & 55.8 & 43.8 & 52.9 \\
\hline high risk of UE & 53.9 & 25.0 & 30.0 & 43.3 & 50.1 & 23.2 & 36.5 & 28.2 & 14.8 & 46.3 & 25.3 & 31.9 & 16.2 & 33.0 & 30.0 & 47.4 & 34.1 & 22.9 & 40.3 & 38.6 & 30.6 & 27.0 & 34.0 & 40.2 & 32.5 & 46.0 & 31.5 & 41.6 \\
\hline
\end{tabular}




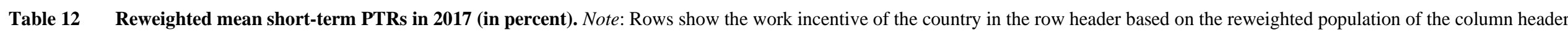
under a fixed tax-benefit system. Each column shows the work incentive of the country in the column header with fixed population characteristics but the tax-benefit system of the row header. The diagonal shows the original work incentive. Source: own calculations using EUROMOD version H1.0

\begin{tabular}{|c|c|c|c|c|c|c|c|c|c|c|c|c|c|c|c|c|c|c|c|c|c|c|c|c|c|c|c|c|}
\hline & BE & BG & CZ & DK & DE & EE & IE & EL & ES & FR & HR & IT & CY & LV & LT & LU & HU & MT & NL & AT & PL & PT & RO & SI & SK & FI & SE & UK \\
\hline$B E$ & 74.3 & 5.7 & 74.7 & 75.4 & 76.1 & 75.5 & 73.5 & 70.4 & 73.9 & 75.1 & 75.3 & 72.9 & 4.6 & 75.3 & 4.8 & 76.7 & 75.4 & 76.5 & 74.0 & 75.1 & 72.6 & 76.3 & 71.7 & 74.9 & 74.8 & 73.9 & 75.0 & 75.8 \\
\hline BG & 1.2 & 1.8 & 60.5 & 3.3 & 63.0 & 61.8 & 60.8 & 56.0 & 60.1 & 61.6 & 60.7 & 58.9 & 0.4 & 61.0 & 1.4 & 61.6 & 61.5 & 59.8 & 60.4 & 59.3 & 57.3 & 61.3 & 59.1 & 61.7 & 60.2 & 51.0 & 62.4 & 60.6 \\
\hline CZ & 8.5 & 490 & 49.4 & 49.1 & 48.9 & 48.9 & 48.8 & 51.3 & & 48.6 & & 50.9 & 48.4 & 49.3 & 9.3 & 48.8 & 49.0 & 49.9 & 49.8 & 49.1 & 50.6 & 51.4 & 51.8 & 48.1 & 49.1 & 49.2 & 49.1 & 50.7 \\
\hline DK & 74.3 & 74.9 & 75.5 & 75.2 & 74.5 & 74.2 & 75.0 & 75.8 & 74.0 & 74.9 & 75.2 & 74.9 & 75.3 & 74.9 & 75.1 & 73.4 & 75.0 & 72.9 & 75.1 & 74.6 & 75.6 & 73.6 & 77.5 & 74.6 & 75.1 & 75.1 & 75.3 & 73.8 \\
\hline DE & 69.6 & 69.6 & 68.4 & 70.6 & 70.8 & 70.0 & 69.2 & 64.9 & 67.6 & 69.7 & 69.3 & 67.1 & 68.9 & 69.4 & 69.3 & 69.9 & 69.5 & 69.2 & 68.6 & 69.2 & 66.8 & 68.2 & 68.0 & 69.8 & 68.4 & 69.2 & 70.2 & 68.4 \\
\hline EE & 51.2 & 52.1 & 52.4 & 52.0 & 52.3 & 51.4 & 52.1 & 51.0 & 52.3 & 51.8 & 53.1 & 53.0 & 52.2 & 51.9 & 51.9 & 51.6 & 51.9 & 53.8 & 51.6 & 52.2 & 51.7 & 53.2 & 52.0 & 52.5 & 52.3 & 51.9 & 51.9 & 52.7 \\
\hline IE & 46.8 & 46.8 & 46.9 & 46.7 & 46.5 & 46.1 & 47.5 & 48.1 & 47.4 & 46.8 & 47.2 & 48.3 & 46.9 & 46.2 & 46.4 & 45.8 & 46.7 & 48.3 & 46.7 & 46.1 & 46.5 & 47.3 & 48.5 & 46.8 & 46.8 & 46.9 & 46.3 & 47.2 \\
\hline EL & 60.4 & 61.4 & 60.4 & 60.6 & 59.9 & 60.0 & 60.3 & 61.7 & 62.1 & 61.5 & 62.9 & 62.3 & 62.0 & 60.9 & 59.9 & 63.0 & 61.2 & 64.3 & 60.7 & 62.4 & 59.3 & 64.8 & 62.1 & 61.1 & 60.9 & 59.8 & 59.8 & 64.0 \\
\hline ES & 48.1 & 49.8 & 51.3 & 48.4 & 49.3 & 48.8 & 47.5 & 50.9 & 49.8 & 49.1 & 50.0 & 51.3 & 48.8 & 49.5 & 49.0 & 50.2 & 49.8 & 50.4 & 49.3 & 50.3 & 50.0 & 51.8 & 52.0 & 49.2 & 50.9 & 48.1 & 48.2 & 51.0 \\
\hline FR & 77.1 & 77.4 & 76.0 & 77.8 & 78.1 & 77.5 & 76.5 & 72.4 & 75.8 & 77.3 & 76.8 & 74.8 & 76.9 & 77.2 & 76.9 & 78.1 & 77.1 & 77.2 & 76.3 & 76.9 & 74.1 & 77.3 & 74.1 & 77.1 & 76.0 & 76.6 & 77.4 & 77.2 \\
\hline HR & 53.6 & 4.8 & 54.8 & 54.9 & 54.5 & 54.5 & 53.0 & 54.4 & 55.0 & 54.3 & 53.9 & 56.0 & 53.2 & 54.6 & 53.9 & 55.5 & 54.5 & 56.1 & 54.4 & 55.2 & 55.4 & 55.9 & 57.5 & 54.3 & 54.0 & 54.0 & & 55.2 \\
\hline IT & 60.7 & 60.2 & 60.0 & 61.1 & 63.2 & 62.4 & 59.2 & 50.8 & 56.6 & 61.3 & 58.2 & 56.6 & 58.8 & 61.0 & 61.0 & 62.3 & 60.5 & 57.9 & 60.2 & 60.1 & 56.4 & 59.6 & 56.3 & 60.1 & 59.0 & 59.8 & 62.8 & 60.4 \\
\hline CY & 43.2 & 45.0 & 44.8 & 43.2 & 43.7 & 43.5 & 43.1 & 44.5 & 44.9 & 43.5 & 45.3 & 45.7 & 43.4 & 44.3 & 43.6 & 45.0 & 44.8 & 44.7 & 43.2 & 44.2 & 44.7 & 46.4 & 44.8 & 44.2 & 44.7 & 43.1 & 42.6 & 45.2 \\
\hline$L V$ & 53.8 & 53.6 & 52.7 & 54.2 & 54.1 & 53.7 & 54.1 & 52.0 & 53.7 & 53.5 & 53.0 & 52.5 & 53.7 & 53.2 & 53.5 & 54.1 & 53.1 & 54.5 & 53.3 & 53.1 & 51.5 & 54.1 & 50.9 & 53.4 & 52.9 & 53.3 & 54.1 & 54.1 \\
\hline LT & 4 & .6 & 3.9 & 43.8 & 3.3 & 43.3 & 42.5 & & & & & & & & 43.3 & & & 46.0 & & & 43.6 & & 43.6 & 43.6 & 43.3 & 42.7 & 3.2 & 46.7 \\
\hline $\mathbf{L U}$ & 82.8 & 83.7 & 84.8 & 83.1 & 83.1 & 83.0 & 83.2 & 84.7 & 83.8 & 83.4 & 84.0 & 84.9 & 82.9 & 83.2 & 83.1 & 82.8 & 83.6 & 84.8 & 83.5 & 83.6 & 85.0 & 84.3 & 84.8 & 83.7 & 84.4 & 83.2 & 83.7 & 84.2 \\
\hline $\mathrm{HU}$ & 50.0 & 52.0 & 52.3 & 49.8 & 50.5 & 50.1 & 49.8 & 55.8 & 53.0 & 50.4 & 50.6 & 55.9 & 50.8 & 51.1 & 51.1 & 50.4 & 51.1 & 51.0 & 51.7 & 51.5 & 56.1 & 51.9 & 54.3 & 50.1 & 51.9 & 51.3 & 49.4 & 51.7 \\
\hline MT & 35.6 & 36.9 & 36.7 & 35.1 & 36.7 & 35.9 & 35.4 & 38.2 & 37.2 & 35.5 & 38.8 & 37.9 & 36.2 & 36.3 & 35.8 & 36.3 & 36.7 & 38.8 & 35.7 & 37.6 & 36.2 & 38.2 & 37.5 & 36.1 & 36.8 & 35.7 & 4.7 & 37.5 \\
\hline NL & 65.2 & 66.3 & 65.0 & 67.4 & 67.7 & 67.1 & 64.2 & 59.2 & 64.3 & 65.4 & 65.4 & & 63.9 & 65.4 & 65.4 & 66.0 & 65.8 & 63.8 & 64.0 & 65.2 & 61.6 & 65.3 & 59.8 & 65.9 & 64.6 & 64.9 & 65.7 & 64.0 \\
\hline AT & 69.1 & 69.0 & 68.2 & 69.6 & 68.9 & 68.8 & 69.4 & 67.1 & 68.9 & 69.5 & 69.8 & 68.3 & 69.6 & 68.7 & 68.3 & 70.3 & 68.7 & 70.5 & 68.5 & 68.3 & 67.6 & 70.5 & 68.4 & 69.1 & 68.2 & 68.5 & 69.1 & 70.2 \\
\hline PL & 45.9 & 46.6 & 46.6 & 46.7 & 46.0 & 45.9 & 46.4 & 46.0 & 46.0 & 46.7 & 46.6 & 47.6 & 45.5 & 46.1 & 45.9 & 46.3 & 46.4 & 47.6 & 46.5 & 46.5 & 46.4 & 47.8 & 47.3 & 45.8 & 46.0 & 46.2 & 46.5 & 47.9 \\
\hline PT & 73.8 & 74.6 & 74.1 & 75.2 & 75.3 & 75.1 & 73.0 & 68.8 & 72.2 & 74.8 & 74.3 & 71.6 & 73.9 & 74.7 & 74.8 & 74.9 & 74.4 & 73.6 & 73.1 & 73.9 & 71.6 & 74.0 & 71.5 & 74.6 & 74.1 & 73.4 & 75.4 & 73.9 \\
\hline Ro & 46.6 & 48.2 & 46.5 & 48.0 & 48.4 & 47.3 & 46.0 & 43.1 & 46.6 & 47.4 & 47.8 & 46.1 & 46.7 & 47.6 & 47.0 & 47.9 & 47.9 & 48.6 & 46.3 & 47.1 & 44.0 & 48.5 & 44.4 & 47.6 & 46.6 & 46.4 & 47.0 & 47.7 \\
\hline SI & 59.1 & 59.9 & 60.3 & 60.0 & 59.0 & 59.3 & 60.2 & 61.8 & 61.2 & 59.4 & 59.0 & 62.1 & 59.0 & 59.2 & 58.9 & 59.2 & 59.7 & 59.7 & 60.3 & 59.4 & 59.3 & 62.1 & 60.6 & 59.0 & 59.7 & 59.9 & 59.6 & 61.4 \\
\hline SK & 48.1 & 48.0 & 49.1 & 47.7 & 47.7 & 47.8 & 48.3 & 50.5 & 50.0 & 47.9 & 47.9 & 50.9 & 48.1 & 48.0 & 48.2 & 47.3 & 48.0 & 49.0 & 48.7 & 48.0 & 49.1 & 48.8 & 54.2 & 48.1 & 48.6 & 48.6 & 48.1 & 48.3 \\
\hline FI & 70.7 & 70.8 & 70.5 & 70.9 & 70.8 & 70.7 & 70.9 & 70.6 & 71.0 & 70.9 & 71.0 & 70.6 & 71.0 & 70.8 & 70.8 & 71.2 & 70.8 & 71.2 & 70.8 & 70.9 & 70.6 & 71.6 & 71.0 & 70.6 & 70.6 & 70.6 & 70.9 & 71.6 \\
\hline SE & 66.5 & 66.9 & 68.1 & 66.3 & 66.4 & 66.9 & 67.1 & 68.8 & 67.9 & $\begin{array}{l}66.8 \\
\end{array}$ & 65.9 & 68.8 & 66.7 & 66.9 & 66.4 & 67.8 & 66.4 & 68.3 & 67.7 & 66.5 & 69.1 & 69.0 & 70.7 & 66.2 & 66.9 & 66.9 & 66.9 & 68.9 \\
\hline UK & 45.3 & 44.8 & 45.3 & 45.5 & 44.6 & 44.7 & 45.9 & 45.1 & 45.4 & 45.6 & 45.5 & 45.1 & 45.3 & 45.0 & 44.8 & 45.3 & 45.0 & 45.1 & 44.7 & 44.7 & 44.4 & 45.3 & 44.7 & 45.6 & 45.4 & 44.8 & 45.1 & 45.0 \\
\hline
\end{tabular}




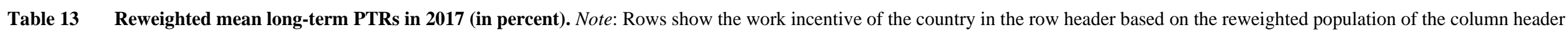
under a fixed tax-benefit system. Each column shows the work incentive of the country in the column header with fixed population characteristics but the tax-benefit system of the row header. The diagonal shows the original work incentive. Source: own calculations using EUROMOD version H1.0

\begin{tabular}{|c|c|c|c|c|c|c|c|c|c|c|c|c|c|c|c|c|c|c|c|c|c|c|c|c|c|c|c|c|}
\hline & BE & BG & CZ & DK & DE & EE & IE & EL & ES & FR & HR & IT & CY & LV & LT & LU & HU & MT & NL & AT & PL & PT & RO & SI & SK & FI & SE & UK \\
\hline BE & 48.1 & 48.9 & 48.8 & 48.3 & 48.5 & 48.8 & 48.7 & 50.3 & 50.3 & 47.8 & 48.6 & 49.4 & 8.6 & 48.7 & 48.6 & 49.2 & 48.5 & 51.3 & 48.5 & 48.8 & 49.1 & 50.8 & 48.5 & 48.3 & 49.1 & 48.5 & 48.0 & 0.2 \\
\hline BG & 5.2 & 25.3 & 25.4 & 5.2 & 24.3 & 24.6 & 26.4 & 28.7 & 27.9 & 25.5 & 25.6 & 28.1 & 5.8 & 25.1 & 24.8 & 25.9 & 25.1 & 29.4 & 26.0 & 25.6 & 26.9 & 28.5 & 28.1 & 25.1 & 5.2 & 25.4 & 5.1 & 8.3 \\
\hline CZ & 5.1 & 34.7 & 34.8 & & 33.9 & 34.5 & 36.3 & 37.5 & & 35.0 & 5.4 & 38.2 & 6.2 & 35.2 & 4.9 & 36.3 & 34.5 & 38.4 & 36.1 & 35.8 & 37.7 & 38.2 & 38.3 & 34.6 & 35.0 & 35.2 & 34.8 & 38.0 \\
\hline DK & 57.3 & 58.0 & 57.3 & 56.8 & 56.7 & 56.7 & 57.4 & 60.6 & 59.1 & 57.7 & 59.7 & 58.6 & 60.0 & 57.9 & 57.5 & 58.7 & 57.7 & 60.4 & 57.8 & 57.7 & 58.9 & 59.3 & 61.4 & 57.9 & 58.2 & 57.3 & 56.5 & 59.4 \\
\hline DE & 43.8 & 44.3 & 44.5 & 44.3 & 43.5 & 44.0 & 44.3 & 45.7 & 45.1 & 43.8 & 44.5 & 46.2 & 43.9 & 44.3 & 43.7 & 44.6 & 44.2 & 45.7 & 44.3 & 44.0 & 45.5 & 45.5 & 46.7 & 44.2 & 43.9 & 44.2 & 43.8 & 45.2 \\
\hline EE & 35.0 & 36.6 & 37.0 & 35.2 & 35.0 & 34.5 & 36.8 & 37.1 & 38.8 & 35.6 & 38.5 & 39.7 & 37.2 & 35.8 & 35.4 & 35.4 & 36.2 & 40.8 & 36.0 & 36.6 & 36.5 & 39.3 & 37.2 & 36.5 & 37.1 & 36.2 & 35.0 & 38.5 \\
\hline IE & 44.3 & 45.5 & 45.9 & 43.6 & 44.3 & 44.4 & 44.2 & 46.6 & 45.1 & 44.4 & 46.2 & 46.7 & 44.4 & 44.5 & 44.1 & 44.0 & 45.4 & 46.5 & 44.2 & 43.6 & 44.6 & 45.0 & 48.4 & 45.1 & 45.7 & 44.5 & 43.3 & 44.4 \\
\hline EL & 39.7 & 40.6 & 41.1 & 39.0 & 38.8 & 39.5 & 40.4 & 45.8 & 42.6 & 39.7 & 41.6 & 44.0 & 40.9 & 40.6 & 40.2 & 39.9 & 40.5 & 42.3 & 40.6 & 40.9 & 42.4 & 42.5 & 44.2 & 40.0 & 41.1 & 40.1 & 38.5 & 41.6 \\
\hline ES & 30.8 & 32.5 & 35.3 & 30.8 & 32.2 & 31.5 & 31.3 & 36.2 & 32.1 & 31.0 & 32.9 & 34.1 & 31.3 & 32.2 & 32.6 & 30.6 & 32.7 & 31.8 & 31.9 & 32.9 & 34.7 & 31.6 & 36.0 & 32.2 & 35.2 & 31.6 & 30.9 & 31.4 \\
\hline FR & 39.7 & 40.4 & 40.9 & 39.7 & 40.0 & 40.0 & 39.4 & 40.1 & 40.2 & 39.9 & 40.5 & 40.6 & 40.1 & 40.3 & 39.7 & 40.7 & 40.4 & 41.0 & 40.1 & 40.4 & 40.9 & 41.0 & 40.2 & 40.4 & 40.6 & 39.8 & 39.7 & 41.1 \\
\hline HR & 31.4 & 29.8 & 29.8 & 31.2 & 30.6 & 31.5 & 31.7 & 31.2 & 31.5 & 30.8 & 28.7 & 29.9 & 30.7 & 30.9 & 31.1 & 31.3 & 29.8 & 32.0 & 31.4 & 30.9 & 32.0 & 30.2 & 30.6 & 29.8 & 29.6 & 31.1 & & 31.1 \\
\hline IT & 25.5 & 24.1 & 25.5 & 25.3 & 24.9 & 26.2 & 25.4 & 24.8 & 23.7 & 24.8 & 22.8 & 24.1 & 23.7 & 24.9 & 25.6 & 23.7 & 24.6 & 22.1 & 25.7 & 24.5 & 25.6 & 21.9 & 24.8 & 24.8 & 24.9 & 25.8 & 26.3 & 22.8 \\
\hline CY & 30.4 & 33.4 & 33.5 & 29.9 & 30.8 & 30.8 & 30.2 & 35.3 & 34.3 & 30.2 & 33.3 & 36.1 & 30.7 & 32.1 & 31.1 & 32.5 & 32.8 & 32.3 & 31.0 & 32.1 & 34.0 & 35.8 & 35.2 & 31.8 & 32.9 & 30.6 & 28.7 & 33.4 \\
\hline$L V$ & 30.9 & 30.9 & 30.9 & 30.4 & 31.1 & 30.2 & 32.5 & 33.6 & 32.7 & 30.6 & 31.5 & 32.7 & 31.5 & 30.2 & 30.4 & 31.6 & 30.4 & 34.4 & 31.2 & 31.0 & 31.4 & 34.3 & 31.7 & 30.5 & 30.8 & 30.8 & 30.4 & 34.1 \\
\hline LT & .0 & 25.2 & 24.7 & 25.2 & 24.0 & 24.4 & 25.6 & 27.5 & & 24.6 & 25.7 & & 25.6 & 25.0 & 24.8 & & 24.9 & 26.9 & & 24.5 & 26.0 & 28.5 & 26.0 & 25.3 & 24.7 & 24.9 & 24.0 & 27.7 \\
\hline $\mathbf{L U}$ & 44.9 & 46.0 & 45.4 & 45.4 & 44.5 & 45.3 & 47.2 & 50.0 & 48.9 & 44.5 & 46.2 & 48.1 & 46.3 & 45.2 & 45.0 & 43.6 & 45.4 & 48.2 & 45.4 & 45.0 & 46.9 & 47.6 & 46.3 & 45.3 & 45.5 & 45.9 & 44.9 & 47.0 \\
\hline $\mathrm{HU}$ & 40.9 & 42.7 & 42.8 & 39.6 & 40.7 & 40.8 & 40.8 & 47.1 & 44.8 & 40.4 & 41.8 & 46.1 & 42.5 & 41.9 & 41.7 & 41.3 & 41.5 & 42.7 & 41.9 & 42.0 & 46.4 & 43.4 & 44.2 & 41.0 & 42.8 & 41.7 & 39.5 & 42.3 \\
\hline MT & 31.4 & 33.1 & 32.8 & 30.7 & 32.3 & 31.8 & 31.2 & 34.8 & 33.3 & 31.3 & 35.2 & 33.5 & 32.1 & 32.3 & 32.1 & 31.3 & 32.9 & 34.9 & 31.5 & 33.5 & 32.7 & 33.4 & 33.3 & 32.2 & 33.2 & 31.8 & 0.3 & 33.0 \\
\hline NL & 33.2 & 35.5 & 34.7 & 34.0 & 34.1 & 34.5 & 32.2 & 32.8 & 35.1 & 33.4 & 36.1 & & 33.8 & 34.7 & 33.9 & 35.3 & 34.8 & 35.2 & 32.7 & 33.7 & 33.5 & 37.3 & 32.3 & 34.3 & 35.3 & 33.2 & 32.1 & 35.3 \\
\hline AT & 48.5 & 48.5 & 47.9 & 47.4 & 46.5 & 47.6 & 49.7 & 52.4 & 52.2 & 48.2 & 49.8 & 51.2 & 50.4 & 48.3 & 47.6 & 50.0 & 47.8 & 53.6 & 48.6 & $\begin{array}{l}47.8 \\
\end{array}$ & 50.5 & 53.7 & 50.3 & 48.3 & 48.5 & 48.4 & 47.1 & 53.0 \\
\hline PL & 35.0 & 34.7 & 34.3 & 35.2 & 34.1 & 34.3 & 35.8 & 34.7 & 35.1 & 35.4 & 34.9 & 34.7 & 34.8 & 34.1 & 34.1 & 35.0 & 34.4 & 36.2 & 34.9 & 34.8 & 33.9 & 35.3 & 34.4 & 34.6 & 34.0 & 34.8 & 35.0 & 35.5 \\
\hline PT & 41.5 & 41.7 & 42.5 & 41.5 & 41.3 & 40.8 & 43.0 & 44.4 & 43.1 & 41.5 & 42.7 & 43.6 & 42.1 & 41.2 & 41.5 & 41.2 & 41.8 & 42.9 & 41.6 & 41.9 & 42.5 & 42.3 & 43.3 & 41.8 & 42.1 & 41.9 & 41.2 & 41.8 \\
\hline Ro & 29.3 & 29.6 & 28.7 & 29.6 & 29.6 & 29.4 & 29.6 & 29.1 & 30.0 & 29.4 & 29.6 & 29.5 & 29.7 & 29.6 & 29.4 & 29.5 & 29.3 & 31.4 & 29.1 & 29.1 & 28.4 & 30.2 & 29.1 & 29.4 & 28.7 & 29.3 & 29.1 & 29.9 \\
\hline SI & 40.8 & 40.3 & 40.0 & 40.0 & 39.4 & 40.1 & 43.1 & $\begin{array}{l}44.8 \\
\end{array}$ & 43.4 & 40.2 & 40.4 & 42.5 & 41.8 & 40.0 & 39.7 & 40.6 & 39.6 & 42.3 & 41.2 & 40.4 & 41.0 & 42.9 & 41.9 & 39.6 & 40.4 & 40.9 & 39.9 & 42.5 \\
\hline SK & 36.4 & 36.7 & 38.2 & 35.3 & 35.6 & 36.2 & 37.0 & 41.4 & 39.9 & 35.9 & 37.1 & 41.4 & 36.8 & 37.0 & 37.0 & 35.3 & 36.7 & 38.5 & 37.5 & 37.0 & 39.0 & 37.7 & 44.9 & 36.7 & 37.8 & 37.6 & 35.7 & 36.7 \\
\hline FI & 55.9 & 56.6 & 56.9 & 55.8 & 55.8 & 55.8 & 56.3 & 58.6 & 57.6 & 56.1 & 57.6 & 57.6 & 57.1 & 56.5 & 56.1 & 57.3 & 56.6 & 58.3 & 56.3 & 56.8 & 57.8 & 58.8 & 58.1 & 56.3 & 57.2 & 56.0 & 55.6 & 58.4 \\
\hline SE & 31.1 & 30.9 & 31.3 & 30.7 & 30.5 & 31.0 & 31.5 & 33.4 & 33.5 & $\begin{array}{l}30.8 \\
\end{array}$ & 30.7 & 33.1 & 31.1 & 31.1 & $\begin{array}{l}30.8 \\
\end{array}$ & 32.4 & 30.6 & 34.5 & 31.6 & 30.6 & 32.5 & 34.3 & 34.0 & 30.7 & 30.4 & 31.0 & 30.7 & 33.5 \\
\hline UK & 36.6 & 36.7 & 37.7 & 36.5 & 35.8 & 36.2 & 37.0 & 38.9 & 37.4 & 36.7 & 37.5 & 37.6 & 36.9 & 36.8 & 36.7 & 36.0 & 36.9 & 36.7 & 36.2 & 36.6 & 37.3 & 36.3 & 37.6 & 37.4 & 37.9 & 36.5 & 36.1 & 35.7 \\
\hline
\end{tabular}




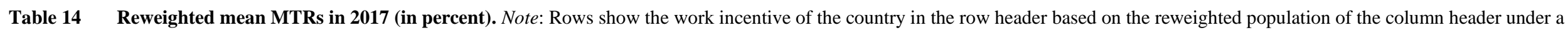
fixed tax-benefit system. Each column shows the work incentive of the country in the column header with fixed population characteristics but the tax-benefit system of the row header. The diagonal shows the original work incentive. Source: own calculations using EUROMOD version H1.0

\begin{tabular}{|c|c|c|c|c|c|c|c|c|c|c|c|c|c|c|c|c|c|c|c|c|c|c|c|c|c|c|c|c|}
\hline & BE & BG & CZ & DK & DE & EE & IE & EL & ES & FR & HR & IT & CY & LV & LT & LU & HU & MT & NL & AT & PL & PT & RO & SI & SK & FI & SE & UK \\
\hline$B E$ & 54.2 & 4.1 & 54.5 & 54.4 & 54.6 & 54.6 & 53.6 & 52.7 & 53.5 & 54.1 & 53.8 & 53.4 & 3.8 & 54.3 & 4.4 & 54.5 & 54.2 & 53.2 & 54.1 & 54.2 & 53.7 & 53.6 & 53.4 & 54.3 & 54.3 & 54.0 & 54.5 & 53.6 \\
\hline BG & 1.4 & 21.9 & 22.1 & 1.3 & 21.0 & 21.2 & 21.6 & 3.5 & 22.7 & 21.6 & 2.0 & 23.1 & 1.8 & 21.6 & 1.5 & 21.7 & 21.7 & 23.3 & 21.8 & 22.1 & 22.9 & 22.8 & 23.4 & 21.6 & 2.1 & 21.6 & 1.2 & 22.6 \\
\hline CZ & 9.4 & 29.3 & 28.5 & & 29.4 & 29.6 & 29.7 & 28.8 & & 29.4 & & 29.7 & 9.5 & 29.4 & 9.1 & 30.4 & 29.1 & 31.7 & 29.5 & 28.5 & 29.1 & 30.6 & 29.4 & 29.1 & 8.5 & 29.2 & 29.5 & 30.7 \\
\hline DK & 46.1 & 45.4 & 45.5 & 46.0 & 46.0 & 45.9 & 46.5 & 45.7 & 45.7 & 45.8 & 44.9 & 45.7 & 45.5 & 45.5 & 45.7 & 45.4 & 45.3 & 45.0 & 46.0 & 45.4 & 45.2 & 44.9 & 45.4 & 45.5 & 45.4 & 46.1 & 46.0 & 45.2 \\
\hline DE & 45.6 & 46.3 & 45.4 & 5.1 & 45.3 & 45.7 & 46.2 & 49.0 & 48.7 & 45.6 & 45.9 & 48.5 & 46.2 & 46.0 & 45.5 & 46.7 & 45.7 & 49.5 & 46.3 & 45.7 & 47.5 & 49.5 & 50.1 & 45.8 & 45.3 & 45.9 & 45.4 & 49.1 \\
\hline EE & 23.2 & 23.1 & 23.5 & 23.1 & 23.1 & 23.1 & 23.8 & 23.7 & 23.2 & 23.3 & 24.2 & 24.0 & 23.7 & 23.3 & 23.4 & 23.0 & 23.3 & 22.7 & 23.5 & 23.2 & 23.1 & 23.2 & 23.5 & 23.6 & 23.6 & 23.7 & 23.1 & 23.4 \\
\hline IE & 40.0 & 37.4 & 37.3 & 39.9 & 38.8 & 39.2 & 41.2 & 37.9 & 39.2 & 38.9 & 36.8 & 37.4 & 38.6 & 38.4 & 39.4 & 38.2 & 37.7 & 36.5 & 39.2 & 39.5 & 39.7 & 37.4 & 36.7 & 38.5 & 37.2 & 39.7 & 40.0 & 37.6 \\
\hline EL & 33.7 & 31.9 & 33.0 & 33.3 & 33.5 & 33.3 & 34.7 & 32.6 & 31.0 & 32.7 & 31.4 & 31.4 & 32.2 & 32.5 & 33.6 & 30.5 & 32.3 & 28.3 & 33.1 & 32.2 & 32.4 & 28.0 & 30.9 & 32.7 & 32.7 & 33.9 & 33.7 & 28.8 \\
\hline ES & 26.1 & 24.9 & 25.0 & 26.2 & 26.6 & 26.4 & 25.9 & 22.5 & 23.5 & 25.2 & 24.0 & 23.0 & 24.7 & 25.4 & 26.1 & 24.4 & 25.1 & 22.2 & 25.4 & 25.1 & 24.5 & 21.9 & 22.8 & 25.4 & 25.0 & 26.1 & 26.6 & 22.5 \\
\hline FR & 39.7 & 40.3 & 40.8 & 39.6 & 39.9 & 39.7 & 40.1 & 42.3 & 41.5 & 39.5 & 40.4 & 42.1 & 40.0 & 40.1 & 39.7 & 40.6 & 40.0 & 42.1 & 40.3 & 40.6 & 41.3 & 42.3 & 42.4 & 39.9 & 40.6 & 40.3 & 39.2 & 42.0 \\
\hline HR & 30.7 & 29.7 & 28.2 & 30.5 & 31.5 & 31.0 & 30.0 & 25.1 & 28.6 & 29.8 & 28.1 & 25.8 & 29.4 & 29.6 & 30.5 & 29.1 & 29.6 & 28.4 & 29.2 & 28.9 & 26.2 & 27.4 & 24.9 & 29.7 & 28.8 & 29.9 & & 27.7 \\
\hline IT & 42.4 & 40.9 & 42.4 & 42.7 & 41.9 & 43.7 & 42.4 & 38.8 & 39.3 & 42.1 & 39.7 & 40.2 & 40.6 & 41.8 & 42.3 & 41.8 & 41.4 & 38.8 & 42.3 & 40.9 & 41.5 & 38.9 & 40.9 & 41.8 & 41.3 & 42.3 & 43.7 & 39.9 \\
\hline CY & 24.0 & 24.4 & 22.6 & 24.1 & 22.9 & 23.7 & 24.1 & 25.0 & 25.9 & 23.6 & 23.4 & 25.4 & 23.4 & 23.7 & 23.4 & 24.5 & 23.9 & 25.2 & 23.9 & 22.9 & 23.2 & 26.3 & 24.5 & 23.6 & 22.1 & 24.4 & 23.3 & 25.6 \\
\hline$L V$ & 31.2 & 31.5 & 30.8 & 31.2 & 31.0 & 31.1 & 31.0 & 31.7 & 31.9 & 31.2 & 31.6 & 31.4 & 31.6 & 31.1 & 31.1 & 32.3 & 31.2 & 32.5 & 31.1 & 31.1 & 31.0 & 33.1 & 31.0 & 31.2 & 30.9 & 31.0 & 31.0 & 32.7 \\
\hline LT & 4 & 26.7 & 26.4 & & 26.7 & 26.4 & & 25.9 & 26.2 & 26.3 & & 25.6 & 26.4 & 26.5 & 26.6 & 26.3 & 26.8 & 26.7 & & 26.8 & 26.1 & 27.1 & 25.6 & 26.5 & 26.5 & 26.2 & 6.4 & 26.7 \\
\hline $\mathbf{L U}$ & 46.3 & 47.3 & 47.1 & 45.8 & 46.3 & 45.7 & 47.4 & 49.9 & 47.7 & 45.9 & 47.5 & 47.6 & 46.9 & 46.2 & 46.7 & 43.7 & 46.6 & 49.2 & 46.1 & 46.5 & 46.8 & 45.7 & 46.9 & 46.4 & 46.9 & 46.8 & 46.4 & 45.8 \\
\hline $\mathrm{HU}$ & 30.1 & 29.4 & 19.9 & 30.5 & 31.1 & 27.7 & 37.6 & 37.7 & 36.3 & 30.3 & 29.0 & 34.9 & 31.6 & 32.2 & 30.1 & 31.8 & 29.1 & 36.4 & 32.1 & 23.3 & 16.6 & 42.3 & 42.0 & 28.6 & 19.5 & 32.6 & 33.1 & 40.8 \\
\hline MT & 25.4 & 25.9 & 25.6 & 25.9 & 24.9 & 25.4 & 24.8 & 25.3 & 25.5 & 25.5 & 26.2 & 24.7 & 25.3 & 25.5 & 25.6 & 25.2 & 25.8 & 25.8 & 25.3 & 25.7 & 25.8 & 25.3 & 25.9 & 26.2 & 26.0 & 25.6 & 5.7 & 25.2 \\
\hline NL & 42.5 & 42.3 & 41.6 & 44.9 & 43.5 & 45.1 & 42.6 & 41.3 & 42.1 & 42.0 & & 41.4 & 42.2 & 42.0 & 42.3 & 41.4 & 41.8 & 40.7 & 41.3 & 42.7 & 42.3 & 41.1 & 40.3 & 42.4 & 41.8 & 42.4 & 42.3 & 40.4 \\
\hline AT & 42.5 & 42.5 & 42.8 & 42.3 & 42.2 & 42.5 & 42.6 & $\begin{array}{l}44.8 \\
\end{array}$ & $\begin{array}{l}43.8 \\
\end{array}$ & 42.2 & 42.2 & 43.1 & 42.7 & 42.6 & 42.7 & 41.6 & 42.4 & $\begin{array}{l}41.8 \\
\end{array}$ & 42.4 & 42.3 & 43.4 & 42.4 & 43.1 & 42.4 & 42.9 & 42.8 & 42.1 & 42.3 \\
\hline PL & 31.3 & 31.5 & 30.2 & 31.4 & 31.3 & 31.0 & 31.4 & 29.5 & 31.4 & 31.4 & 31.8 & 29.8 & 31.5 & 30.9 & 30.9 & 31.2 & 31.3 & 32.4 & 30.7 & 31.2 & 29.5 & 31.7 & 29.4 & 31.2 & 30.5 & 31.1 & 31.2 & 31.6 \\
\hline PT & 36.4 & 35.2 & 34.7 & 36.5 & 37.2 & 36.6 & 36.3 & 32.4 & 33.5 & 35.3 & 33.9 & 32.5 & 35.0 & 35.5 & 36.8 & 33.6 & 35.2 & 31.8 & 35.4 & 35.3 & 32.8 & 31.0 & 32.1 & 35.4 & 34.9 & 36.3 & 36.9 & 31.5 \\
\hline Ro & 31.6 & $\begin{array}{l}31.8 \\
\end{array}$ & 31.4 & 31.9 & 31.7 & 31.5 & 31.8 & 32.3 & 32.3 & 31.7 & 31.9 & 32.0 & 31.8 & 31.7 & 31.7 & 31.8 & 31.7 & 33.5 & 31.6 & 31.6 & 31.7 & 32.4 & 33.0 & 31.7 & 31.4 & 31.7 & 31.7 & 32.2 \\
\hline SI & 39.9 & 40.0 & 39.2 & 40.0 & 40.3 & 39.9 & 40.4 & 38.4 & 40.1 & 39.7 & 40.0 & 39.2 & 40.0 & 39.9 & 39.9 & 40.5 & 39.8 & 40.6 & 39.4 & 39.8 & 38.6 & 40.6 & 37.2 & 39.7 & 39.2 & 39.7 & 39.9 & 40.7 \\
\hline SK & 32.2 & 32.3 & 33.0 & 31.7 & 31.4 & 31.8 & 33.1 & 34.5 & 34.6 & 32.1 & 32.5 & 34.6 & 32.7 & 32.0 & 32.0 & 31.7 & 32.2 & 34.2 & 33.1 & 32.4 & 33.1 & 33.7 & 43.7 & 32.3 & 32.8 & 32.8 & 32.1 & 33.4 \\
\hline FI & 45.8 & 45.2 & 44.9 & 45.8 & 45.5 & 45.6 & 46.0 & 45.9 & 45.6 & 45.4 & 45.1 & 44.9 & 45.6 & 45.4 & 45.8 & 44.8 & 45.5 & 45.3 & 45.6 & 45.7 & 45.3 & 44.3 & 45.4 & 45.4 & 45.4 & 45.6 & 45.8 & 44.7 \\
\hline SE & 38.7 & 37.7 & 38.2 & 38.6 & 38.3 & 38.3 & 39.3 & 40.3 & 39.6 & 38.0 & 36.9 & 39.5 & 37.7 & 37.9 & $\begin{array}{l}38.3 \\
\end{array}$ & 37.9 & \begin{tabular}{|l|l}
37.8 \\
\end{tabular} & 38.1 & 38.9 & 37.9 & 38.9 & 38.5 & 40.2 & 38.1 & 37.5 & 38.9 & 38.7 & 38.0 \\
\hline UK & 39.8 & 39.0 & 39.6 & 39.9 & 38.9 & 39.1 & 40.7 & 40.4 & 39.7 & 39.9 & 39.9 & 39.4 & 39.7 & 39.3 & 39.3 & 39.1 & 39.3 & 39.0 & 39.2 & 39.2 & 39.0 & 38.8 & 39.3 & 40.0 & 39.7 & 39.7 & 39.8 & 38.9 \\
\hline
\end{tabular}




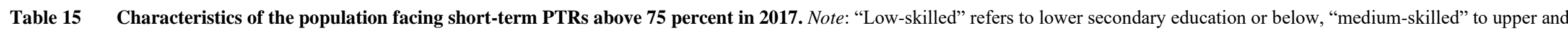
post secondary education and "high-skilled" to tertiary education. "Self-employed" are defined as those with self-employment income, who do not have employment income."Part-time" is defined as working less than 30 hours per week. "Main earner" is the individual with the highest earnings in the household. High risk of unemployment (UE) refers to the 10\% of the sample with the highest risk. Source: own calculations using EUROMOD version H1.0

\begin{tabular}{|c|c|c|c|c|c|c|c|c|c|c|c|c|c|c|c|c|c|c|c|c|c|c|c|c|c|c|c|c|}
\hline & BE & BG & CZ & DK & DE & $\mathbf{E E}$ & IE & EL & ES & FR & HR & IT & CY & LV & LT & LU & HU & MT & NL & AT & PL & PT & RO & SI & SK & FI & SE & UK \\
\hline Imple size & 3180 & 1646 & 252 & 3147 & 5266 & 376 & 366 & 1744 & 1305 & 8444 & 167 & 1911 & 314 & 133 & 194 & 3353 & 546 & 219 & 4646 & 1110 & 780 & 5129 & 349 & 1285 & 248 & 2264 & 1174 & 1188 \\
\hline sample & 1.0 & 1.9 & 3.9 & 9.7 & 8.5 & 5.9 & 7.6 & & 2.2 & 01 & & & 7.2 & 2.1 & 4.8 & 84.0 & 8.9 & 5.1 & 39.4 & & 6.0 & 63.7 & 4.9 & 11.8 & 4.3 & 20.3 & 20.5 & 7.1 \\
\hline$\%$ male & 6.4 & 48.4 & 48.8 & 43.6 & 57.9 & 49.0 & 39.4 & 49.8 & 49.8 & 51.1 & 43.8 & 33.5 & 59.0 & 40.7 & 56.0 & 51.9 & 52.9 & 59.3 & 68.6 & 42.5 & 52.6 & 45.7 & 63.2 & 57.1 & 59.9 & 48.4 & 44.3 & 48.5 \\
\hline female & 3.6 & 51.6 & 51.2 & 56.4 & 42.1 & 51.0 & 60.6 & 50.2 & 50.2 & 48.9 & 56.2 & 66.5 & 41.0 & 59.3 & 44.0 & 48.1 & 47.1 & 40.7 & 31.4 & 57.5 & 47.4 & 54.3 & 36.8 & 42.9 & 40.1 & 51.6 & 55.7 & 51.5 \\
\hline$\%$ age $(<30)$ & 20.7 & 1.2 & 16.0 & 9.8 & 9.2 & 24.3 & 15.2 & 20.1 & 16.7 & 18.3 & 12.0 & 10.5 & 14.4 & 14.5 & 27.3 & 17.4 & 20.7 & 57.5 & 7.6 & 26.3 & 10.4 & 10.8 & 33.6 & 6.0 & 21.2 & 22.7 & 33.5 & 19.0 \\
\hline$\%$ age $(30-50)$ & 58.2 & 51.8 & 54.6 & 57.8 & 63.5 & 51.9 & 57.3 & 62.7 & 63.5 & 58.3 & 61.5 & 40.0 & 63.7 & 53.4 & 57.5 & 65.3 & 32.7 & 28.9 & 54.9 & 60.7 & 56.0 & 65.7 & 44.2 & 57.8 & 61.3 & 54.9 & 46.7 & 59.4 \\
\hline 0 age $(50+)$ & 21.0 & 47.0 & 29.4 & 32.5 & 27.3 & 23.8 & 27.5 & 17.2 & 19.7 & 23.4 & 26.4 & 49.5 & 21.9 & 32.1 & 15.2 & 17.4 & 46.6 & 13.6 & 37.5 & 13.0 & 33.6 & 23.4 & 22.1 & 36.3 & 17.5 & 22.4 & 19.7 & 21.6 \\
\hline$\%$ low-skilled & 15.0 & 12.6 & 4.8 & 14.1 & 5.3 & 15.7 & 26.4 & 29.3 & 48.4 & 12.9 & 22.3 & 37.5 & 30.9 & 29.2 & 14.1 & 31.6 & 18.4 & 51.6 & 17.9 & 21.8 & 12.5 & 52.8 & 65.8 & 17.5 & 3.4 & 16.3 & 15.6 & 54.2 \\
\hline$\%$ medium-skilled & 43.0 & 65.7 & 79.7 & 52.6 & 53.0 & 60.1 & 36.7 & 49.0 & 23.9 & 47.5 & \begin{tabular}{|l|} 
\\
70.1
\end{tabular} & 47.1 & 54.2 & 59.4 & 67.7 & 40.2 & 63.3 & 31.7 & 40.2 & 58.5 & 69.9 & 26.7 & 28.4 & 64.2 & 82.8 & 49.5 & 51.7 & 26.9 \\
\hline$\%$ high-skilled & 42.1 & 21.7 & 15.4 & 33.3 & 41.8 & 24.2 & 37.0 & 21.7 & 27.7 & 39.6 & 7.5 & 15.4 & 14.9 & 11.4 & 18.2 & 28.2 & 18.2 & 16.7 & 41.9 & 19.7 & 17.6 & 20.5 & 5.8 & 18.2 & $\mid 13.8$ & 34.2 & 32.7 & 18.9 \\
\hline$\%$ employee & 98.5 & 99.4 & 34.4 & 95.7 & 99.3 & 93.9 & 79.5 & 74.1 & 79.4 & 99.3 & 55.2 & 98.7 & 82.0 & 88.5 & 95.8 & 95.3 & 60.3 & 84.1 & 99.5 & 92.4 & 62.0 & 97.8 & 13.1 & 69.5 & 37.6 & 91.9 & 92.3 & 87.6 \\
\hline 0 self-employed & 1.5 & 0.6 & 65.6 & 4.3 & 0.7 & 6.1 & 20.5 & 25.9 & 20.6 & 0.7 & 44.8 & 1.0 & 18.0 & 11.5 & 4.2 & 4.7 & 39.7 & 15.9 & 0.5 & 7.6 & 38.0 & 2.2 & 86.9 & 30.5 & 62.4 & 8.1 & 7.7 & 12.4 \\
\hline$\%$ main earner & 59.6 & 63.4 & 49.3 & 55.3 & 70.1 & 63.6 & 68.3 & 57.3 & 61.8 & 67.0 & 59.9 & 43.5 & 78.1 & 86.3 & 60.8 & 64.5 & 51.5 & 40.2 & 85.1 & 54.9 & 44.8 & 61.4 & 50.3 & 50.2 & 59.7 & 66.5 & 51.5 & 71.0 \\
\hline$\%$ secondary earner & 40.4 & 36.6 & 50.7 & 44.7 & 29.9 & 36.4 & 31.7 & 42.7 & 38.2 & 33.0 & 40.1 & 56.5 & 21.9 & 13.7 & 39.2 & 35.5 & 48.5 & 59.8 & 14.9 & 45.1 & 55.2 & 38.6 & 49.7 & 49.8 & 40.3 & 33.5 & 48.5 & 29.0 \\
\hline$\%$ part-timer & 19.4 & 5.0 & 19.6 & 12.3 & 10.6 & 26.1 & 61.6 & 45.3 & 43.2 & 11.6 & 19.9 & 26.9 & 23.8 & 39.3 & 29.1 & 16.6 & 24.3 & 33.4 & 16.5 & 41.1 & 15.4 & 5.8 & 24.2 & 16.8 & 10.2 & 27.9 & 6.6 & 47.6 \\
\hline \% earnings Q1 & 17.6 & 8.9 & 81.6 & 19.4 & 6.3 & 86.7 & 56.5 & 67.5 & 54.8 & 10.5 & 67.1 & 25.2 & 5.6 & 89.4 & 90.8 & 15.1 & 45.3 & 91.1 & 14.2 & 40.2 & 67.1 & 16.0 & 93.1 & 42.9 & 77.4 & 39.8 & 48.4 & 54.2 \\
\hline$\%$ earnings Q2 & 25.4 & 24.4 & 14.7 & 29.7 & 18.1 & 11.8 & 34.1 & 23.0 & 40.8 & 21.4 & 22.6 & 32.1 & 65.7 & 10.6 & 6.4 & 22.2 & 30.9 & 5.3 & 5.0 & 44.6 & 27.9 & 18.6 & 0.9 & 25.1 & 8.5 & 25.0 & 46.8 & 15.3 \\
\hline \% earnings Q3 & 29.1 & 25.8 & 2.4 & 31.8 & 18.5 & 1.5 & 7.8 & 8.6 & 4.3 & 23.3 & 7.7 & 25.2 & 24.8 & 0.0 & 2.8 & 22.8 & 8.4 & 3.6 & 12.1 & 10.5 & 4.4 & 22.4 & 1.5 & 27.3 & 4.6 & 14.5 & 2.4 & 16.9 \\
\hline \% earnings Q4 & 25.5 & 23.2 & 1.3 & 17.3 & 25.7 & 0.0 & 1.6 & 0.8 & 0.2 & 23.0 & 2.6 & 15.9 & 4.0 & 0.0 & 0.0 & 23.4 & 8.6 & 0.0 & 32.0 & 4.3 & 0.5 & 27.3 & 1.0 & 4.5 & 5.3 & 12.4 & 1.2 & 10.3 \\
\hline$\%$ earnings Q5 & 2.4 & 17.6 & 0.0 & 1.7 & 31.5 & 0.0 & 0.0 & 0.0 & 0.0 & 21.8 & 0.0 & 1.6 & 0.0 & 0.0 & 0.0 & 16.5 & 6.8 & 0.0 & 36.8 & 0.4 & 0.0 & 15.7 & 3.5 & 0.2 & 4.2 & 8.3 & 1.2 & 3.4 \\
\hline$\%$ poverty risk & 3.4 & 9.2 & 53.0 & 4.9 & 3.3 & 73.8 & 19.9 & 33.5 & 62.0 & 2.4 & 36.4 & 9.4 & 56.4 & 97.0 & 65.7 & 9.1 & 43.0 & 27.5 & 7.8 & 32.6 & 36.2 & 9.5 & 83.2 & 28.5 & 53.7 & 14.8 & 23.1 & 21.0 \\
\hline$\%$ high risk of UE & 12.6 & 6.5 & 22.2 & 5.9 & 5.7 & 14.9 & 10.9 & 13.3 & 18.2 & 9.1 & 19.2 & 7.3 & 5.4 & 46.1 & 32.2 & 9.4 & 15.5 & 21.7 & 10.3 & 22.5 & 11.4 & 9.2 & 14.1 & 10.5 & 14.2 & 17.8 & 21.8 & 23.3 \\
\hline
\end{tabular}




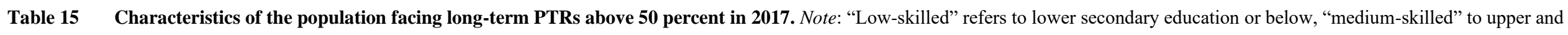
post secondary education and "high-skilled" to tertiary education. "Self-employed" are defined as those with self-employment income, who do not have employment income."Part-time" is defined as working less than 30 hours per week. "Main earner" is the individual with the highest earnings in the household. High risk of unemployment (UE) refers to the 10\% of the sample with the highest risk. Source: own calculations using EUROMOD version H1.0

\begin{tabular}{|c|c|c|c|c|c|c|c|c|c|c|c|c|c|c|c|c|c|c|c|c|c|c|c|c|c|c|c|c|}
\hline & BE & BG & CZ & DK & DE & EE & IE & EL & ES & FR & HR & IT & CY & LV & LT & LU & HU & MT & NL & AT & PL & PT & RO & SI & SK & FI & SE & UK \\
\hline mple size & 2160 & 100 & 895 & 2698 & 3184 & 663 & 1492 & 3416 & 1417 & 2183 & 153 & 353 & 1058 & 424 & 234 & 1206 & 1133 & 953 & 1069 & 2065 & 1637 & 2732 & 542 & 1575 & 1075 & 7255 & 483 & 3677 \\
\hline sample & & 2.2 & 12.9 & 9.7 & & 10.7 & & & 3.6 & & & 1.8 & & 6.8 & 6.7 & & & 21.3 & 15.9 & 36.2 & 13.3 & 32.7 & 7.6 & 19.5 & 18.0 & 2.6 & 10.2 & 21.5 \\
\hline male & 3.6 & 57.1 & 52.4 & 57.4 & 57.5 & 49.8 & 59.5 & 65.4 & 57.2 & 57.4 & 50.5 & 61.7 & 54.0 & 43.1 & 65.5 & 61.5 & 56.1 & 65.5 & 58.5 & 61.1 & 53.8 & 53.3 & 67.0 & 62.0 & 63.6 & 50.9 & 62.9 & 60.8 \\
\hline female & 1.4 & 42.9 & 47.6 & 42.6 & 42.5 & 50.2 & 40.5 & 34.6 & 42.8 & 42.6 & 49.5 & 38.3 & 46.0 & 56.9 & 34.5 & 38.5 & 43.9 & 34.5 & 41.5 & 38.9 & 46.2 & 46.7 & 33.0 & 38.0 & 36.4 & 49.1 & 37.1 & 39.2 \\
\hline$\%$ age $(<30)$ & 21.9 & 19.8 & 15.5 & 19.7 & 22.7 & 27.2 & 17.0 & 12.4 & 10.3 & 20.8 & 13.2 & 10.4 & 21.1 & 15.9 & 34.2 & 12.6 & 33.6 & 50.3 & 37.2 & 26.4 & 14.6 & 13.2 & 30.7 & 14.0 & 12.3 & 17.5 & 20.7 & 19.8 \\
\hline$\%$ age $(30-50)$ & 52.9 & 58.1 & 62.2 & 58.4 & 51.5 & 51.0 & 54.5 & 62.8 & 65.8 & 62.4 & 68.2 & 40.6 & 57.6 & 55.2 & 55.6 & 67.9 & 43.5 & 33.4 & 39.9 & 55.0 & 71.2 & 63.8 & 50.6 & 67.0 & 65.8 & 56.9 & 50.7 & 60.9 \\
\hline 0 age $(50+)$ & 25.2 & 22.1 & 22.3 & 21.9 & 25.8 & 21.7 & 28.5 & 24.8 & 23.9 & 16.7 & 18.6 & 49.0 & 21.2 & 28.8 & 10.1 & 19.5 & 23.0 & 16.3 & 22.8 & 18.6 & 14.2 & 23.0 & 18.8 & 19.0 & 21.9 & 25.6 & 28.6 & 19.4 \\
\hline$\%$ low-skilled & 12.9 & 64.6 & 5.1 & 16.6 & 9.5 & 18.1 & 19.0 & 30.1 & 48.5 & 16.5 & 17.0 & 28.0 & 28.8 & 16.6 & 20.6 & 38.4 & 13.8 & 57.5 & 29.1 & 14.6 & 9.5 & 66.1 & 60.5 & 11.9 & 3.1 & 11.9 & 16.9 & 48.9 \\
\hline$\%$ medium-skilled & 34.1 & 31.1 & 79.5 & 47.8 & 60.1 & 58.1 & 33.0 & 43.8 & 23.6 & 56.0 & 73.7 & 35.8 & 49.1 & 66.6 & 63.5 & 34.4 & 63.6 & 30.4 & 46.3 & 55.0 & 71.2 & 23.0 & 34.7 & 64.5 & 76.9 & 45.5 & 47.4 & 26.5 \\
\hline$\%$ high-skilled & 52.9 & 4.4 & 15.4 & 35.7 & 30.4 & 23.8 & 48.0 & 26.1 & 27.9 & 27.4 & 9.3 & 36.2 & 22.1 & 16.8 & 15.9 & 27.2 & 22.7 & 12.0 & 24.6 & 30.5 & 19.4 & 10.9 & 4.8 & 23.6 & 20.0 & 42.6 & 35.6 & 24.7 \\
\hline$\%$ employee & 88.7 & 74.0 & 60.7 & 95.9 & 94.9 & 94.0 & 84.5 & 41.8 & 63.0 & 91.4 & 67.3 & 25.1 & 86.3 & 91.7 & 92.6 & 93.8 & 64.7 & 87.1 & 98.5 & 90.6 & 81.2 & 92.5 & 23.7 & 81.6 & 38.8 & 93.0 & 86.8 & 86.0 \\
\hline self-employed & 1.3 & 26.0 & 39.3 & 4.1 & 5.1 & 6.0 & 15.5 & 58.2 & 37.0 & 8.6 & 32.7 & 72.5 & 13.7 & 8.3 & 7.4 & 6.2 & 35.3 & 12.9 & 1.5 & 9.4 & 18.8 & 7.5 & 76.3 & 18.4 & 61.2 & 7.0 & 13.2 & 14.0 \\
\hline$\%$ main earner & 76.8 & 87.3 & 72.2 & 75.8 & 75.2 & 71.8 & 73.6 & 77.9 & 75.1 & 75.7 & 76.9 & 63.2 & 76.9 & 95.5 & 77.9 & 91.0 & 51.7 & 50.3 & 80.4 & 82.6 & 56.1 & 86.9 & 58.7 & 80.6 & 69.1 & 71.8 & 93.2 & 88.6 \\
\hline$\%$ secondary earner & 23.2 & 12.7 & 27.8 & 24.2 & 24.8 & 28.2 & 26.4 & 22.1 & 24.9 & 24.3 & 23.1 & 36.8 & 23.1 & 4.5 & 22.1 & 9.0 & 48.3 & 49.7 & 19.6 & 17.4 & 43.9 & 13.1 & 41.3 & 19.4 & 30.9 & 28.2 & 6.8 & 11.4 \\
\hline$\%$ part-timer & 11.3 & 43.6 & 9.7 & 10.5 & 13.4 & 19.2 & 32.1 & 22.9 & 35.3 & 13.0 & 17.0 & 10.7 & 21.1 & 19.7 & 17.6 & 13.2 & 13.4 & 11.0 & 35.2 & 17.1 & 9.3 & 7.5 & 18.6 & 11.9 & 6.2 & 14.0 & 12.5 & 20.7 \\
\hline \% earnings Q1 & 17.5 & 83.4 & 43.4 & 22.1 & 20.2 & 58.5 & 24.6 & 36.4 & 39.7 & 15.5 & 46.7 & 23.6 & 26.6 & 43.4 & 64.3 & 17.3 & 30.6 & 38.1 & 30.6 & 23.7 & 29.4 & 22.4 & 80.2 & 29.1 & 36.7 & 17.9 & 25.4 & 22.8 \\
\hline \% earnings Q2 & 18.2 & 10.1 & 21.5 & 21.7 & 26.6 & 26.2 & 24.8 & 19.3 & 41.1 & 28.9 & 32.0 & 14.5 & 33.7 & 36.3 & 25.1 & 24.0 & 32.2 & 42.8 & 28.8 & 21.7 & 34.8 & 29.0 & 9.3 & 27.1 & 14.9 & 22.1 & 26.4 & 21.0 \\
\hline \% earnings Q3 & 17.9 & 4.9 & 18.2 & 20.8 & 22.3 & 11.2 & 14.8 & 13.8 & 16.0 & 26.2 & 13.3 & 9.9 & 25.3 & 14.9 & 7.9 & 23.4 & 16.1 & 16.6 & 22.5 & 19.4 & 24.7 & 25.4 & 4.7 & 19.4 & 12.7 & 19.6 & 20.5 & 22.5 \\
\hline \% earnings Q4 & 17.3 & 1.3 & 12.2 & 16.9 & 18.4 & 3.6 & 13.4 & 14.2 & 3.0 & 19.8 & 7.9 & 11.8 & 10.7 & 5.2 & 2.0 & 16.6 & 9.7 & 2.1 & 13.7 & 18.5 & 9.0 & 15.5 & 3.2 & 12.7 & 13.4 & 18.6 & 12.8 & 19.1 \\
\hline$\%$ earnings Q5 & 29.2 & 0.4 & 4.6 & 18.5 & 12.5 & 0.5 & 22.5 & 16.2 & 0.1 & 9.6 & 0.2 & 40.2 & 3.7 & 0.3 & 0.6 & 18.8 & 11.4 & 0.4 & 4.4 & 16.7 & 2.0 & 7.8 & 2.6 & 11.7 & 22.3 & 21.8 & 15.0 & 14.6 \\
\hline$\%$ poverty risk & 5.7 & 81.0 & 25.4 & 5.7 & 11.7 & 61.9 & 7.7 & 24.9 & 62.8 & 5.4 & 50.7 & 8.6 & 33.8 & 73.0 & 67.2 & 21.1 & 30.6 & 14.0 & 16.0 & 19.4 & 19.3 & 24.8 & 74.2 & 32.1 & 23.0 & 5.8 & 24.3 & 10.9 \\
\hline$\%$ high risk of UE & 17.9 & 54.9 & 23.0 & 14.3 & 16.8 & 16.1 & 15.6 & 12.2 & 17.7 & 13.0 & 27.4 & 3.1 & 8.4 & 31.8 & 39.9 & 15.5 & 17.7 & 14.2 & 30.6 & 15.1 & 10.1 & 18.7 & 16.1 & 20.3 & 10.6 & 11.9 & 16.2 & 15.0 \\
\hline
\end{tabular}




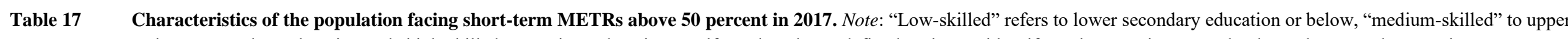
and post secondary education and "high-skilled" to tertiary education. "Self-employed" are defined as those with self-employment income, who do not have employment income."Parttime" is defined as working less than 30 hours per week. "Main earner" is the individual with the highest earnings in the household. Results for Bulgaria omitted due to small sample size. High risk of unemployment (UE) refers to the $10 \%$ of the sample with the highest risk. Source: own calculations using EUROMOD version H1.0

\begin{tabular}{|c|c|c|c|c|c|c|c|c|c|c|c|c|c|c|c|c|c|c|c|c|c|c|c|c|c|c|c|c|}
\hline & $\mathbf{E}$ & BG & CZ & DK & DE & EE & IE & EL & ES & FR & HR & IT & CY & LV & LT & LU & HU & MT & NL & AT & PL & PT & RO & SI & SK & FI & SE & UK \\
\hline Sample size & 18 & 26 & 185 & 1995 & 2200 & 100 & 1508 & 912 & 54 & 1743 & 49 & 3410 & 476 & 86 & 69 & 955 & 372 & 106 & 2553 & 601 & 465 & 496 & 411 & 1077 & 509 & 4143 & 2150 & 3085 \\
\hline$\%$ sample & .4 & - & 2.7 & 28.8 & 21.1 & 1.7 & 32.3 & 8.6 & 0.5 & 17.6 & 0.9 & 21.0 & 9.1 & 1.3 & 2.1 & 25.1 & 7.0 & 2.5 & 24.0 & 11.0 & 3.5 & 6.3 & 5.4 & 1.7 & 9.8 & 1.4 & 4.0 & 16.9 \\
\hline$\%$ male & 5.3 & - & 38.4 & 64.4 & 40.6 & 52.2 & 59.3 & 78.8 & 49.2 & 53.4 & 64.3 & 68.8 & 39.7 & 41.6 & 65.5 & 44.2 & 62.9 & 63.0 & 71.6 & 53.6 & 55.4 & 51.4 & 67.4 & 58.9 & 75.0 & 63.8 & 65.4 & 54.0 \\
\hline$\%$ female & 44.7 & - & 61.6 & 35.6 & 59.4 & 47.8 & 40.7 & 21.2 & 50.8 & 46.6 & 35.7 & 31.2 & 60.3 & 58.4 & 34.5 & 55.8 & 37.1 & 37.0 & 28.4 & 46.4 & 44.6 & 48.6 & 32.6 & 41.1 & 25.0 & 36.2 & 34.6 & 46.0 \\
\hline$\%$ age ( & 5.5 & - & 15.2 & 9.0 & 13.7 & 27.6 & 5.4 & 2.3 & 0.9 & 27.2 & 21.8 & 5.2 & 23.5 & 14.6 & 40.0 & 17.3 & 9.7 & 47.3 & 16.5 & 20.1 & 18.2 & 9.0 & 35.4 & 13.5 & 11.4 & 11.6 & 5.6 & 15.4 \\
\hline$\%$ age $(30-50)$ & 60.8 & - & 68.1 & 59.4 & 54.6 & 52.9 & 67.1 & 63.0 & 76.5 & 53.1 & 42.0 & 68.4 & 58.6 & 57.5 & 50.7 & 61.9 & 62.0 & 34.4 & 58.5 & 52.7 & 65.2 & 66.5 & 40.5 & 68.8 & 67.8 & 57.3 & 60.0 & 66.6 \\
\hline$\%$ age $(50+)$ & 3.6 & - & 16.6 & 31.6 & 31.7 & 19.5 & 27.5 & 34.7 & 22.5 & 19.7 & 36.2 & 26.4 & 17.9 & 27.9 & 9.3 & 20.8 & 28.4 & 18.3 & 25.0 & 27.2 & 16.5 & 24.5 & 24.0 & 17.7 & 20.8 & 31.1 & 34.4 & 17.9 \\
\hline$\%$ low-skilled & 10.5 & - & 10.7 & 10.5 & 9.1 & 14.9 & 13.6 & 13.6 & 32.1 & 17.9 & 14.9 & 26.0 & 34.1 & 34.8 & 24.9 & 24.4 & 5.8 & 58.6 & 16.7 & 14.3 & 14.8 & 34.3 & 72.8 & 13.5 & 1.6 & 8.1 & 7.7 & 51.5 \\
\hline$\%$ medium-skilled & 36.2 & - & 78.1 & 36.1 & 54.4 & 62.4 & 16.9 & 31.1 & 15.9 & 55.0 & 42.8 & 44.9 & 46.1 & 55.5 & 65.3 & 36.3 & 59.6 & 30.9 & 37.5 & 47.9 & 70.4 & 18.2 & 26.4 & 62.3 & 75.8 & 30.0 & 39.8 & 25.6 \\
\hline$\%$ high-skilled & 53.2 & - & 11.2 & 53.4 & 36.6 & 22.7 & 69.5 & 55.3 & 52.0 & 27.0 & 42.3 & 29.1 & 19.7 & 9.7 & 9.8 & 39.3 & 34.6 & 10.5 & 45.8 & 37.8 & 14.8 & 47.5 & 0.9 & 24.2 & 22.6 & 61.9 & 52.5 & 22.9 \\
\hline$\%$ employee & 92.7 & - & 89.9 & 95.5 & 94.7 & 94.3 & 90.9 & 44.8 & 96.6 & 90.5 & 97.0 & 80.5 & 89.1 & 85.0 & 100.0 & 93.2 & 40.7 & 87.2 & 95.7 & 73.6 & 93.2 & 94.1 & 3.9 & 86.2 & 11.9 & 94.5 & 94.3 & 84.3 \\
\hline$\%$ self-employed & 7.3 & - & 10.1 & 4.5 & 5.3 & 5.7 & 9.1 & 55.2 & 3.4 & 9.5 & 3.0 & 19.2 & 10.9 & 15.0 & 0.0 & 6.8 & 59.3 & 12.8 & 4.3 & 26.4 & 6.8 & 5.9 & 96.1 & 13.8 & 88.1 & 5.5 & 5.7 & 15.7 \\
\hline$\%$ main earner & 67.0 & - & 76.1 & 87.7 & 60.9 & 88.9 & 77.3 & 94.7 & 79.2 & 71.6 & 93.8 & 84.8 & 64.2 & 82.1 & 84.5 & 65.6 & 67.9 & 51.4 & 89.0 & 71.1 & 66.8 & 71.8 & 48.3 & 74.4 & 78.2 & 82.2 & 84.1 & 84.2 \\
\hline$\%$ secondary earner & 33.0 & - & 23.9 & 12.3 & 39.1 & 11.1 & 22.7 & 5.3 & 20.8 & 28.4 & 6.2 & 15.2 & 35.8 & 17.9 & 15.5 & 34.4 & 32.1 & 48.6 & 11.0 & 28.9 & 33.2 & 28.2 & 51.7 & 25.6 & 21.8 & 17.8 & 15.9 & 15.8 \\
\hline$\%$ part-timer & 10.9 & - & 9.8 & 5.2 & 27.2 & 26.2 & 18.4 & 4.2 & 15.3 & 21.7 & 7.0 & 4.4 & 34.6 & 42.5 & 32.7 & 20.7 & 3.1 & 26.0 & 17.6 & 26.8 & 20.8 & 8.5 & 24.4 & 11.4 & 4.9 & 10.2 & 3.4 & 29.1 \\
\hline \% earnings Q1 & 7.2 & - & 44.5 & 8.2 & 30.0 & 93.4 & 8.7 & 5.3 & 6.7 & 29.7 & 29.4 & 1.5 & 65.5 & 97.2 & 89.5 & 18.0 & 5.0 & 72.3 & 11.9 & 30.2 & 44.6 & 25.1 & 96.4 & 24.1 & 18.2 & 12.1 & 7.4 & 33.2 \\
\hline \% earnings Q2 & 21.7 & - & 38.2 & 9.9 & 15.9 & 6.6 & 9.8 & 2.1 & 23.3 & 34.9 & 8.7 & 3.7 & 25.0 & 2.2 & 2.9 & 14.4 & 15.9 & 22.3 & 13.1 & 31.5 & 27.7 & 14.4 & 2.6 & 39.5 & 13.4 & 4.8 & 2.9 & 29.4 \\
\hline \% earnings Q3 & 22.9 & - & 11.5 & 9.7 & 9.2 & 0.0 & 10.8 & 6.4 & 40.8 & 15.5 & 8.5 & 11.2 & 3.9 & 0.0 & 7.6 & 11.9 & 26.7 & 5.4 & 23.1 & 7.2 & 13.6 & 2.5 & 1.0 & 15.3 & 14.3 & 2.7 & 2.4 & 16.0 \\
\hline \% earnings Q4 & 23.6 & - & 4.8 & 7.5 & 28.5 & 0.0 & 20.0 & 4.8 & 15.3 & 0.1 & 4.0 & 40.6 & 2.9 & 0.0 & 0.0 & 39.6 & 19.8 & 0.0 & 12.7 & 14.4 & 7.6 & 7.1 & 0.0 & 7.9 & 18.8 & 16.6 & 26.4 & 6.1 \\
\hline \% earnings Q5 & 24.7 & - & 1.0 & 64.6 & 16.3 & 0.0 & 50.7 & 81.4 & 13.9 & 11.8 & 49.4 & 43.1 & 2.7 & 0.6 & 0.0 & 16.1 & 32.7 & 0.0 & 39.3 & 16.7 & 6.5 & 50.9 & 0.0 & 13.1 & 35.4 & 63.8 & 60.9 & 15.3 \\
\hline$\%$ poverty risk & 1.2 & - & 30.7 & 1.2 & 14.7 & 100.0 & 1.7 & 7.5 & 27.5 & 9.4 & 34.1 & 2.5 & 41.7 & 97.8 & 87.8 & 18.2 & 10.4 & 24.6 & 9.8 & 31.5 & 27.3 & 28.1 & 88.0 & 31.7 & 21.3 & 5.8 & 6.9 & 12.1 \\
\hline$\%$ high risk of UE & 9.1 & - & 42.5 & 7.2 & 14.1 & 19.9 & 7.9 & 4.4 & 6.0 & 20.0 & 28.9 & 5.3 & 10.4 & 49.2 & 59.5 & 11.9 & 7.8 & 24.2 & 10.3 & 14.2 & 19.5 & 14.9 & 14.1 & 15.8 & 9.7 & 8.4 & 4.3 & 17.4 \\
\hline
\end{tabular}


Table 18 Characteristics of the population facing short-term PTRs above 120 percent of the median in each country in 2017. Note: "Low-skilled" refers to lower secondary education or below, "medium-skilled" to upper and post secondary education and "high-skilled" to tertiary education. "Self-employed" are defined as those with self-employment income, who do not have employment income."Part-time" is defined as working less than 30 hours per week. "Main earner" is the individual with the highest earnings in the household. Results for

Luxembourg omitted due to small sample size. High risk of unemployment (UE) refers to the $10 \%$ of the sample with the highest risk. Source: own calculations using EUROMOD version H1.0

\begin{tabular}{|c|c|c|c|c|c|c|c|c|c|c|c|c|c|c|c|c|c|c|c|c|c|c|c|c|c|c|c|c|}
\hline & BE & BG & CZ & DK & E & EE & IE & EL & ES & FR & HR & IT & CY & LV & LT & LU & $\mathrm{HU}$ & MT & NL & AT & PL & PT & RO & SI & SK & FI & SE & UK \\
\hline Imple size & 246 & 1155 & 1644 & 896 & 334 & 563 & 1124 & 2571 & 3375 & 281 & 432 & 1229 & 1176 & 159 & 1128 & 21 & 1254 & 1836 & 393 & 909 & 3392 & 603 & 958 & 2370 & 602 & 577 & 560 & 5465 \\
\hline (t) & & 1.7 & & 5.5 & & 3.8 & & 5.0 & 0.3 & 2.8 & 8.4 & & 4.5 & 2.5 & 24.6 & & & 41.0 & 5.9 & 16.5 & 27.1 & 7.8 & 13.4 & 21.4 & 10.4 & 4.9 & 9.9 & 31.1 \\
\hline male & 7.9 & 47.8 & 53.6 & 36.8 & 65.0 & 48.6 & 49.4 & 52.4 & 52.6 & 48.0 & 43.5 & 30.7 & 54.7 & 42.7 & 52.6 & & 57.2 & 64.8 & 65.7 & 38.9 & 53.5 & 26.4 & 54.7 & 53.7 & 63.1 & 48.9 & 48.8 & 53.6 \\
\hline female & 2.1 & 2.2 & 46.4 & 63.2 & & 51.4 & 0.6 & 47.6 & 47.4 & 2.0 & 56.5 & 69.3 & 45.3 & 57.3 & 47.4 & - & 42.8 & 35.2 & 34.3 & 61.1 & 46.5 & 73.6 & 45.3 & 46.3 & 36.9 & 51.1 & 51.2 & 46.4 \\
\hline age $(<30)$ & 7.4 & 15 & 7.6 & 15.2 & 35.7 & 21.2 & 12.6 & 19.1 & 18.3 & 26.6 & 6.8 & 10.4 & 19.6 & 15.9 & 16.4 & & 19.5 & 43.5 & 31.0 & 26.4 & 12.6 & 13.1 & 18.0 & 4.4 & 17.0 & 21.4 & 30.7 & 17.1 \\
\hline$\%$ age $(30-50)$ & 0.4 & 37.7 & 38.3 & 54.3 & 54.8 & 54.3 & 53.9 & 62.8 & 61.5 & 51.5 & \begin{tabular}{|l|}
73.3 \\
\end{tabular} & 41.1 & 59.1 & 53.4 & 38.0 & & 32.6 & 38.1 & 46.7 & 61.8 & 53.7 & 63.8 & 58.6 & 56.4 & 62.2 & 50.2 & 47.7 & 63.2 \\
\hline age $(50+)$ & 2.2 & 60.8 & 54.1 & 30.5 & 9.5 & 24.5 & 33.5 & 18.2 & 20.2 & 21.9 & 19.9 & 48.5 & 21.3 & 30.7 & 45.5 & - & 47.9 & 18.4 & 22.3 & 11.8 & 33.8 & 23.2 & 23.4 & 39.3 & 20.9 & 28.4 & 21.6 & 19.7 \\
\hline low-skilled & 28.4 & 12.7 & 3.7 & 18.5 & 21.7 & 17.2 & 20.7 & 28.6 & 45.4 & 25.6 & 21.8 & 39.0 & 27.4 & 26.1 & 7.3 & - & 15.1 & 50.0 & 26.2 & 22.3 & 9.6 & 55.7 & 45.9 & 18.0 & 3.1 & 15.1 & 17.5 & 49.6 \\
\hline$\%$ med & 45.7 & 68.2 & 80.4 & 53.1 & 50.6 & 57.7 & 31.8 & 48.6 & 25.0 & 55.9 & 70.9 & 47.3 & 48.9 & 62.1 & 70.5 & - & 62.5 & 28.8 & 53.0 & 58.2 & 72.3 & 21.5 & 50.7 & 66.2 & 78.3 & 54.0 & 51.9 & 26.1 \\
\hline 0 high-skilled & 25.9 & 19.2 & 15.9 & 28.4 & 27.7 & 25.1 & 47.6 & 22.7 & 29.6 & 18.4 & 7.3 & 13.7 & 23.7 & 11.8 & 22.2 & - & 22.4 & 21.2 & 20.9 & 19.5 & 18.1 & 22.8 & 3.4 & 15.8 & 18.6 & 30.9 & 30.6 & 24.3 \\
\hline employee & 2.2 & 99.3 & 62.2 & 89.4 & 99.3 & 95.1 & 84.4 & 72.6 & 84.7 & 898 & 72.3 & 98.1 & 86.5 & 88.4 & 98.0 & - & 67.2 & 90.2 & 98.2 & 92.9 & 81.4 & 94.4 & 60.8 & 79.2 & 38.6 & 77.4 & 86.7 & 89.9 \\
\hline self-employed & 7.8 & 0.7 & 37.8 & 10.6 & 0.7 & 4.9 & 15.6 & 27.4 & 15.3 & 10.2 & 27.7 & 1.6 & 13.5 & 11.6 & 2.0 & & 32.8 & 9.8 & 1.8 & 7.1 & 18.6 & 5.6 & 39.2 & 20.8 & 61.4 & 22.6 & 13.3 & 10.1 \\
\hline 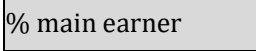 & 7.0 & 62.8 & 61.0 & 44.3 & 54.4 & 61.3 & 71.5 & 61.9 & 66.3 & 42.9 & 57.8 & 41.0 & 76.4 & 88.5 & 55.9 & & 57.4 & 54.2 & 78.3 & 49.6 & 57.0 & 31.1 & 54.0 & 54.4 & 66.4 & 70.1 & 57.9 & 78.3 \\
\hline$\%$ secondary earner & 43.0 & 37.2 & 39.0 & 55.7 & 45.6 & 38.7 & 28.5 & 38.1 & 33.7 & 57.1 & 42.2 & 59.0 & 23.6 & 11.5 & 44.1 & - & 42.6 & 45.8 & 21.7 & 50.4 & 43.0 & 68.9 & 46.0 & 45.6 & 33.6 & 29.9 & 42.1 & 21.7 \\
\hline$\%$ part-timer & 67.6 & 6.1 & 6.7 & 24.9 & 15.1 & 24.2 & 41.2 & 36.3 & 30.3 & 37.7 & 12.5 & 29.7 & 20.2 & 36.3 & 9.8 & & 15.7 & 9.7 & 47.8 & 46.5 & 10.6 & 25.3 & 11.4 & 13.5 & 8.9 & 29.6 & 10.1 & 27.6 \\
\hline \% earnings Q1 & 95.7 & 10.6 & 31.1 & 48.6 & 42.7 & 78.8 & 31.0 & 52.8 & 24.3 & (1.0 & 43.9 & 34.0 & 24.8 & 81.3 & 32.4 & & 33.9 & 25.6 & 60.8 & 47.0 & 31.9 & 61.8 & 45.4 & 28.9 & 50.1 & 53.6 & 62.4 & 30.1 \\
\hline \% earnings Q2 & 4.3 & 23.9 & 24.8 & 48.3 & 12.2 & 16.9 & 25.9 & 31.7 & 36.9 & 12.6 & 32.8 & 35.8 & 30.7 & 16.7 & 32.1 & & 19.6 & 25.2 & 18.1 & 44.4 & 28.4 & 4.3 & 42.4 & 27.0 & 13.9 & 29.5 & 33.9 & 19.8 \\
\hline \% earnings Q3 & 0.0 & 27.4 & 16.8 & 1.3 & 12.7 & 3.4 & 14.8 & 9.9 & 27.2 & 5.4 & 20.1 & 19.7 & 24.6 & 1.9 & 22.8 & & 17.5 & 22.8 & & 7.0 & 24.1 & 5.8 & 7.9 & 29.3 & 10.2 & 8.6 & 1.0 & 19.2 \\
\hline \% earnings Q4 & 0.0 & 22.2 & 18.1 & 1.3 & 17.1 & 0.9 & 12.7 & 5.2 & 11.3 & 1.2 & 3.3 & 9.7 & 12.5 & 0.0 & 11.9 & & 15.9 & 16.1 & 3.7 & 1.4 & 13.9 & 22.6 & 3.0 & 13.9 & 10.9 & 5.4 & 0.8 & 16.8 \\
\hline \% earnings Q5 & 0.0 & 15.9 & 9.2 & 0.4 & 15.2 & 0.0 & 15.6 & 0.4 & & 1.4 & & & 7.4 & 0.0 & & - & 13.1 & 10.2 & 8.6 & 0.1 & 1.8 & 5.6 & 1.3 & 0.9 & 15.0 & 2.9 & 1.8 & 14.0 \\
\hline$\% 0$ poverty 11sк & 30.1 & 10.3 & 16.2 & 14.1 & 10.8 & 62.3 & 8.2 & 27.5 & 34.1 & 15.4 & 23.0 & 12.7 & 30.6 & 95.3 & 24.8 & & 26.7 & 7.8 & 36.4 & 36.8 & 17.5 & 15.8 & 40.0 & 21.5 & 37.1 & 18.0 & 39.3 & 8.5 \\
\hline$\%$ high risk of UE & 28.7 & 6.8 & 12.3 & 9.2 & 13.5 & 12.6 & 11.1 & 13.6 & 17.2 & 17.9 & 9.6 & 7.6 & 7.8 & 44.7 & 13.3 & & 13.0 & 11.4 & 26.6 & 22.5 & 10.3 & 10.5 & 8.3 & 9.7 & 13.8 & 13.1 & 23.0 & 14.4 \\
\hline threshold & 93.3 & 80.4 & 57.8 & 89.9 & 89.8 & 66.6 & 54.0 & 66.8 & 52.8 & 95.6 & 67.2 & 77.8 & 47.1 & 69.7 & 49.9 & 105.3 & 56.5 & 36.5 & 85.7 & 82.3 & 51.0 & 95.0 & 59.2 & 69.8 & 59.1 & 85.0 & 77.5 & 48.9 \\
\hline
\end{tabular}


Table 19 Characteristics of the population facing long-term PTRs above 120 percent of the median in each country in 2017. Note: "Low-skilled" refers to lower secondary education or below, "medium-skilled" to upper and post secondary education and "high-skilled" to tertiary education. "Self-employed" are defined as those with self-employment income, who do not have employment income."Part-time" is defined as working less than 30 hours per week. "Main earner" is the individual with the highest earnings in the household. High risk of unemployment (UE) refers to the $10 \%$ of the sample with the highest risk. Source: own calculations using EUROMOD version H1.0

\begin{tabular}{|c|c|c|c|c|c|c|c|c|c|c|c|c|c|c|c|c|c|c|c|c|c|c|c|c|c|c|c|c|}
\hline & BE & BG & CZ & DK & DE & EE & IE & EL & ES & FR & HR & IT & CY & LV & LT & LU & $\mathrm{HU}$ & MT & NL & AT & PL & PT & RO & SI & SK & FI & SE & UK \\
\hline ample size & 1040 & 1390 & 2136 & 1806 & 2960 & 1691 & 1240 & 3165 & 3577 & 2840 & 1395 & 6299 & 2133 & 981 & 1054 & 1181 & 1789 & 1898 & 3474 & 1692 & 3404 & 3405 & 1699 & 2358 & 2775 & 2299 & 1817 & 6386 \\
\hline sample & 9.8 & 0.1 & 0.3 & 37.3 & 29.0 & 27.5 & 5.6 & \begin{tabular}{|l|}
30.2 \\
\end{tabular} & 3.4 & 30.0 & 26.6 & 36.3 & \begin{tabular}{|l|}
45.0 \\
\end{tabular} & 15.9 & 27.6 & 32.6 & 28.6 & 42.4 & 33.8 & 29.9 & 28.3 & 41.2 & 24.1 & 28.7 & 43.4 & 22.2 & 31.7 & 36.7 \\
\hline$\%$ male & 6.2 & 55.2 & 57.6 & 53.5 & 56.8 & 48.0 & 59.7 & 64.7 & 59.6 & 58.2 & 54.7 & 61.6 & \begin{tabular}{|l|}
58.8 \\
\end{tabular} & 50.4 & 53.4 & 61.1 & 56.3 & 67.2 & 68.4 & 59.9 & 58.4 & 55.7 & 64.4 & 61.3 & 61.8 & 49.8 & 65.4 & 60.3 \\
\hline female & 3.8 & 44.8 & 42.4 & 46.5 & 43.2 & 52.0 & 40.3 & 35.3 & 40.4 & 41.8 & 45.3 & 38.4 & 41.2 & 49.6 & 46.6 & 38.9 & 43.7 & 32.8 & 31.6 & 40.1 & 41.6 & 44.3 & 35.6 & 38.7 & 38.2 & 50.2 & 34.6 & 39.7 \\
\hline age $(<30)$ & 20.0 & 10.9 & 12.7 & 22.1 & 22.4 & 24.5 & 17.8 & 12.0 & 7.4 & 19.9 & 16.3 & 6.5 & 17.0 & 13.8 & 29.5 & 12.8 & 31.3 & 42.4 & 22.4 & 29.0 & 12.8 & 11.1 & 27.1 & 14.3 & 24.4 & 29.5 & 11.6 & 18.0 \\
\hline$\%$ age $(30-50)$ & 55.7 & 65.9 & 65.0 & 58.6 & 51.9 & 51.1 & 52.5 & 62.6 & 66.0 & 61.9 & 56.5 & 59.8 & 58.8 & 57.5 & 47.9 & 67.7 & 47.8 & 38.0 & 43.5 & 54.0 & 72.8 & 65.0 & 53.5 & 66.6 & 57.6 & 46.4 & 58.7 & 60.9 \\
\hline 0 age $(50+)$ & 24.3 & 23.3 & 22.3 & 19.2 & 25.7 & 24.3 & 29.7 & 25.4 & 26.6 & 18.1 & 27.3 & 33.7 & 24.3 & 28.8 & 22.6 & 19.5 & 20.9 & 19.7 & 34.1 & 17.0 & 14.4 & 23.9 & 19.4 & 19.1 & 17.9 & 24.1 & 29.7 & 21.1 \\
\hline$\%$ low-skilled & 17.9 & 21.4 & 3.6 & 17.1 & 10.0 & 15.7 & 21.0 & 31.2 & 36.9 & 15.3 & 6.1 & 19.9 & 22.0 & 12.9 & 7.8 & 38.8 & 10.5 & 47.1 & 20.0 & 16.1 & 7.2 & 58.8 & 39.1 & 10.7 & 2.4 & 17.5 & 10.9 & 47.2 \\
\hline$\%$ medium-skilled & 39.0 & 56.1 & 77.4 & 49.0 & 60.6 & 56.6 & 33.7 & 44.2 & 23.6 & 55.4 & 51.3 & 44.0 & 41.9 & 59.9 & 57.7 & 34.3 & 61.4 & 29.0 & 39.5 & 56.1 & 64.7 & 23.0 & 50.0 & 58.4 & 71.9 & 53.2 & 44.2 & 25.7 \\
\hline$\%$ high-skilled & 43.1 & 22.4 & 19.0 & 33.9 & 29.4 & 27.7 & 45.4 & 24.6 & 39.6 & 29.3 & 42.6 & 36.2 & 36.2 & 27.2 & 34.5 & 26.9 & 28.2 & 24.0 & 40.5 & 27.8 & 28.1 & 18.2 & 10.8 & 30.9 & 25.6 & 29.3 & 44.9 & 27.2 \\
\hline$\%$ employee & 85.6 & 72.8 & 65.7 & 96.5 & 94.8 & 96.6 & 84.0 & 39.9 & 75.3 & 92.1 & 82.1 & 63.0 & 88.0 & 94.2 & 84.8 & 93.8 & 75.9 & 89.7 & 96.9 & 90.1 & 82.4 & 92.9 & 68.3 & 84.4 & 70.9 & 88.1 & 93.8 & 87.5 \\
\hline$\%$ self-employed & 14.4 & 27.2 & 34.3 & 3.5 & 5.2 & 3.4 & 16.0 & 60.1 & 24.7 & 7.9 & 17.9 & 35.5 & 12.0 & 5.8 & 15.2 & 6.2 & 24.1 & 10.3 & 3.1 & 9.9 & 17.6 & 7.1 & 31.7 & 15.6 & 29.1 & 11.9 & 6.2 & 12.5 \\
\hline$\%$ main earner & 89.8 & 73.0 & 72.4 & 74.9 & 75.9 & 67.0 & 72.5 & 77.6 & 79.5 & 76.6 & 60.4 & 69.0 & 82.2 & 95.8 & 78.1 & 90.8 & 57.6 & 57.8 & 84.2 & 83.0 & 67.7 & 87.6 & 73.1 & 79.1 & 67.6 & 77.7 & 89.8 & 85.4 \\
\hline$\%$ secondary earner & 10.2 & 27.0 & 27.6 & 25.1 & 24.1 & 33.0 & 27.5 & 22.4 & 20.5 & 23.4 & 39.6 & 31.0 & 17.8 & 4.2 & 21.9 & 9.2 & 42.4 & 42.2 & 15.8 & 17.0 & 32.3 & 12.4 & 26.9 & 20.9 & 32.4 & 22.3 & 10.2 & 14.6 \\
\hline$\%$ part-timer & 16.3 & 7.8 & 7.1 & 11.8 & 14.0 & 13.5 & 34.8 & 23.3 & 19.7 & 11.6 & 4.5 & 5.7 & 13.4 & 11.2 & 8.5 & 13.4 & 9.2 & 7.4 & 23.1 & 17.9 & 6.6 & 6.1 & 6.7 & 9.4 & 3.0 & 26.7 & 6.0 & 18.3 \\
\hline \% earnings Q1 & 29.5 & 18.2 & 27.8 & 24.7 & 21.3 & 37.1 & 28.4 & 38.5 & 18.8 & 12.8 & 12.8 & 6.1 & 15.3 & 21.1 & 22.1 & 17.6 & 20.7 & 21.9 & $\mid 18.2$ & 27.6 & 16.5 & 17.9 & 32.2 & 22.8 & 19.8 & 42.1 & 13.8 & 19.4 \\
\hline \% earnings Q2 & 20.1 & 25.7 & 20.6 & 24.8 & 28.2 & 34.6 & 27.1 & 18.0 & 22.6 & 26.7 & 12.3 & 11.4 & 20.6 & 26.3 & 20.4 & 24.4 & 23.7 & 24.0 & 17.6 & 21.7 & 20.5 & 23.1 & 24.1 & 23.2 & 16.8 & 26.2 & 14.7 & 17.7 \\
\hline \% earnings Q3 & 17.5 & 21.6 & 18.1 & 24.0 & 21.3 & 15.2 & 13.4 & 14.1 & 20.5 & 27.9 & 8.8 & 11.1 & 20.4 & 19.7 & $\mid 18.8$ & 23.6 & 20.2 & 22.3 & 14.0 & 21.2 & 22.7 & 20.4 & 20.4 & 18.6 & 22.5 & 13.5 & 12.8 & 19.9 \\
\hline \% earnings Q4 & 17.5 & 16.3 & 16.7 & 18.2 & 17.7 & 9.7 & 12.4 & 14.4 & 17.5 & 21.1 & 21.9 & 21.0 & 20.4 & 18.3 & 17.9 & 16.6 & 20.2 & 16.0 & 13.4 & 18.5 & 23.1 & 18.7 & 17.7 & 15.1 & 21.1 & 10.3 & 12.3 & 19.3 \\
\hline \% earnings Q5 & 15.4 & 18.2 & 16.8 & 8.3 & 11.5 & 3.3 & 18.6 & 14.9 & 20.7 & 11.5 & 44.2 & 50.4 & 23.4 & 14.6 & 20.8 & 17.7 & 15.2 & 15.7 & 36.8 & 11.0 & \begin{tabular}{|l|}
17.2 \\
\end{tabular} & 19.9 & 5.6 & 20.4 & 19.8 & 7.9 & 46.4 & 23.7 \\
\hline$\%$ poverty risk & 11.4 & 22.3 & 13.9 & 7.4 & 12.5 & 30.6 & 9.3 & 26.4 & 29.7 & 4.7 & 8.0 & 3.2 & 18.1 & 38.3 & 22.1 & 21.5 & 21.2 & 7.3 & 8.0 & 23.2 & 12.0 & 19.7 & 30.9 & 23.5 & 10.3 & 15.7 & 12.5 & 7.3 \\
\hline$\%$ high risk of UE & 29.9 & 17.3 & 16.4 & 15.9 & 17.6 & 14.7 & 16.6 & 12.0 & 13.8 & 11.3 & 7.2 & 5.1 & 7.2 & 23.3 & 21.2 & 15.7 & 14.4 & 9.6 & 17.4 & 17.3 & 8.5 & 16.6 & 18.4 & 17.0 & 10.9 & 23.4 & 8.7 & 12.0 \\
\hline threshold & 57.1 & 26.4 & 37.3 & 59.8 & 50.8 & 36.8 & 52.6 & 51.3 & 34.3 & 46.4 & 32.3 & 30.0 & \begin{tabular}{|l|}
24.8 \\
\end{tabular} & 34.3 & 26.9 & 50.6 & 41.4 & 30.5 & 34.9 & 54.0 & 35.7 & 44.0 & 34.8 & 43.6 & 37.0 & 61.9 & 31.2 & 39.4 \\
\hline
\end{tabular}


Table 20 Characteristics of the population facing METRs above 120 percent of the median in each country in 2017. Note: "Low-skilled" refers to lower secondary education or below, "medium-skilled" to upper and post secondary education and "high-skilled" to tertiary education. "Self-employed" are defined as those with self-employment income, who do not have employment income."Part-time" is defined as working less than 30 hours per week. "Main earner" is the individual with the highest earnings in the household. High risk of unemployment (UE) refers to the $10 \%$ of the sample with the highest risk. Source: own calculations using EUROMOD version H1.0

\begin{tabular}{|c|c|c|c|c|c|c|c|c|c|c|c|c|c|c|c|c|c|c|c|c|c|c|c|c|c|c|c|c|}
\hline & BE & BG & CZ & DK & DE & EE & IE & EL & ES & FR & HR & IT & CY & LV & LT & LU & $\mathrm{HU}$ & MT & NL & AT & PL & PT & RO & SI & SK & FI & SE & UK \\
\hline ample size & 3 & 471 & 495 & 983 & 1169 & 160 & 401 & 2156 & 3247 & 2138 & 2536 & 2408 & 2174 & 88 & 70 & 420 & 397 & 1110 & 667 & 518 & 1136 & 1371 & 591 & 1680 & 1392 & 1392 & 2,362 & 5232 \\
\hline sample & 1.5 & 95 & 8.1 & 28.5 & 11.1 & 2.5 & 8.6 & 20.4 & 25.1 & 22.1 & 47.0 & 14.7 & 43.3 & 1.4 & 2.2 & 11.5 & 7.6 & 25.7 & 9.6 & 9.5 & 9.8 & 17.7 & 8.6 & 17.3 & 22.8 & 9.5 & 37.8 & 29.6 \\
\hline$\%$ male & .3 & 65.7 & 64.0 & 64.3 & 36.3 & 57.2 & 48.4 & 72.8 & 58.6 & 55.0 & 55.8 & 67.5 & 56.9 & 42.0 & 66.4 & 48.4 & 62.6 & 60.3 & 63.1 & 52.2 & 47.7 & 50.0 & 70.1 & 60.3 & 47.8 & 65.4 & 63.3 & 60.2 \\
\hline female & .7 & 34.3 & 36.0 & 35.7 & 63.7 & 42.8 & 51.6 & 27.2 & 41.4 & 45.0 & 44.2 & 32.5 & 43.1 & 58.0 & 33.6 & 51.6 & 37.4 & 39.7 & 36.9 & 47.8 & 52.3 & 50.0 & 29.9 & 39.7 & 52.2 & 34.6 & 36.7 & 39.8 \\
\hline$\%$ age $(<30)$ & 32.0 & 10.7 & 8.3 & 9.0 & 18.4 & 19.6 & 6.8 & 2.7 & 7.1 & 26.4 & 15.3 & 6.4 & 9.5 & 14.2 & 38.9 & 13.8 & 9.7 & 33.6 & 36.7 & 20.8 & 20.3 & 7.2 & 24.3 & 9.7 & 16.2 & 26.1 & 6.3 & 11.6 \\
\hline age ( & 3.4 & 57.5 & 62.2 & 59.3 & 51.3 & 54.2 & 66.5 & 63.9 & 61.6 & 52.5 & 56.4 & 67.0 & 65.3 & 57.6 & 52.0 & 64.9 & 62.8 & 49.8 & 45.8 & 54.0 & 60.2 & 66.7 & 54.8 & 66.7 & 62.6 & 45.9 & 0.0 & 64.8 \\
\hline age ( & 4.6 & 31.8 & 29.5 & 31.7 & 30.3 & 26.3 & 26.7 & 33.5 & 31.3 & 21.1 & 28.3 & 26.6 & 25.2 & 28.2 & 9.1 & 21.3 & 27.5 & 16.6 & 17.5 & 25.2 & 19.5 & 26.1 & 20.9 & 23.6 & 21.2 & 28.0 & 33.7 & 23.6 \\
\hline low_ckilled & 20.3 & 21.8 & 4.9 & 10.4 & 15.7 & 14.2 & 22.3 & 13.2 & 17.0 & 16.1 & 4.8 & 27.3 & 14.3 & 35.4 & 24.3 & 40.9 & 5.5 & 38.8 & 26.6 & 15.9 & 11.0 & 22.5 & 54.9 & 9.6 & 3.0 & 12.1 & 8.2 & 42.9 \\
\hline$\%$ medium-skilled & 0.1 & 48.0 & 75.0 & 36.1 & 57.3 & 59.1 & 22.5 & 36.6 & 21.2 & 53.4 & 58.6 & 44.6 & 34.6 & 54.1 & 66.2 & 36.6 & 60.0 & 33.2 & 49.2 & 48.1 & 60.8 & 23.7 & 41.8 & 49.5 & 77.0 & 36.2 & 40.5 & 23.3 \\
\hline$\%$ high-skilled & 29.6 & 30.2 & 20.1 & 53.4 & 27.0 & 26.8 & 55.2 & 50.2 & 61.9 & 30.5 & 36.5 & 28.1 & 51.1 & 10.4 & 9.5 & 22.5 & 34.5 & 28.0 & 24.2 & 36.0 & 28.3 & 53.9 & 3.3 & 40.9 & 20.0 & 51.7 & 51.3 & 33.8 \\
\hline employee & 4.9 & 17.0 & 34.2 & 95.5 & 91.4 & 80.1 & 93.6 & 42.4 & 95.9 & 89.1 & 93.4 & 75.8 & 91.9 & 83.9 & 100.0 & 86.5 & 44.8 & 91.4 & 95.4 & 72.5 & 97.0 & 97.9 & 38.7 & 87.1 & 57.5 & 90.0 & 94.9 & 85.1 \\
\hline self-employed & 5.1 & 83.0 & 65.8 & 4.5 & 8.6 & 19.9 & 6.4 & 57.6 & 4.1 & 10.9 & 6.6 & 24.0 & 8.1 & 16.1 & 0.0 & 13.5 & 55.2 & 8.6 & 4.6 & 27.5 & 3.0 & 2.1 & 61.3 & 12.9 & 42.5 & 10.0 & 5.1 & 14.9 \\
\hline$\%$ main earner & 54.7 & 64.9 & 79.5 & 87.8 & 60.3 & 85.5 & 80.3 & 90.6 & 74.6 & 72.2 & 62.6 & 82.0 & 76.8 & 82.5 & 82.3 & 68.7 & 68.6 & 58.6 & 80.8 & 68.4 & 53.2 & 68.1 & 62.5 & 77.3 & 50.4 & 81.7 & 83.5 & 85.4 \\
\hline$\%$ secondary earner & 5.3 & 35.1 & 20.5 & 12.2 & 39.7 & 14.5 & 19.7 & 9.4 & 25.4 & 27.8 & 37.4 & 18.0 & 23.2 & 17.5 & 17.7 & 31.3 & 31.4 & 41.4 & 19.2 & 31.6 & 46.8 & 31.9 & 37.5 & 22.7 & 49.6 & 18.3 & 16.5 & 14.6 \\
\hline$\%$ part-timer & 10.9 & 12.5 & 6.1 & 5.3 & 38.2 & 20.5 & 35.6 & 3.9 & 7.9 & 19.4 & 0.7 & 5.1 & 9.4 & 41.5 & 31.8 & 28.2 & 3.5 & 5.0 & 31.4 & 30.1 & 18.1 & 3.9 & 15.8 & 7.8 & 4.2 & 25.9 & 4.3 & 19.1 \\
\hline \% earnings Q1 & 23.8 & 29.2 & 18.3 & 8.3 & 50.2 & 68.3 & 17.3 & 2.2 & 2.3 & 26.6 & 0.6 & 1.8 & 14.0 & 94.8 & 89.8 & 37.1 & 5.0 & 8.2 & 26.3 & 33.9 & 45.0 & 9.6 & 61.4 & 16.3 & 39.3 & 37.3 & 9.3 & 20.9 \\
\hline \% earnings Q2 & 71.1 & 15.2 & 18.9 & 9.8 & 24.0 & 8.4 & 27.4 & 1.1 & & 30.1 & & 4.6 & 6.5 & 2.1 & 2.8 & 29.6 & 16.0 & 8.1 & 26.3 & 35.4 & 24.0 & 6.9 & 4.1 & 26.7 & 22.9 & 9.2 & 5.2 & 17.5 \\
\hline \% earnings Q3 & 3.5 & 15.8 & 6.1 & 9.5 & 10.1 & 10.8 & 16.4 & 4.7 & 18.6 & 16.4 & 24.6 & 8.4 & 2.1 & 0.0 & 7.4 & 12.6 & 25.7 & 53.3 & 40.4 & 6.9 & 7.3 & 3.9 & 14.7 & 11.4 & 9.4 & 2.2 & 3.5 & 10.1 \\
\hline \% earnings Q4 & 1.2 & 16.0 & 20.8 & 7.5 & 10.5 & 2.3 & 15.0 & 20.7 & 11.8 & 10.7 & 28.5 & 48.7 & & 0.0 & & 14.7 & 18.7 & 17.3 & 5.9 & 10.9 & 6.4 & 12.7 & 16.5 & 7.1 & 9.7 & 2.9 & 27.2 & 4.7 \\
\hline$\%$ earnings Q5 & 0.4 & 23.9 & 35.8 & 64.9 & 5.2 & 10.1 & 23.8 & 71.2 & 61.4 & 16.1 & 41.6 & 36.6 & 49.0 & 3.1 & 0.0 & 6.0 & 34.6 & 13.2 & 1.1 & 12.9 & 17.3 & 66.9 & 3.2 & 38.5 & 18.6 & 48.4 & 54.8 & 46.7 \\
\hline$\%$ poverty risk & 5.8 & 23.4 & 14.8 & 1.3 & 27.5 & 76.1 & 4.8 & 4.1 & 1.0 & 8.5 & 0.7 & 2.4 & 9.6 & 95.4 & 85.5 & 39.5 & 10.7 & 3.4 & 20.3 & 36.2 & 22.0 & 10.0 & 63.5 & 21.8 & 11.4 & 17.9 & 8.7 & 7.3 \\
\hline$\%$ high risk of UE & 21.3 & 12.6 & 18.9 & 7.1 & 20.0 & 13.9 & 13.4 & 5.3 & 5.2 & 19.3 & 6.0 & 6.5 & 4.0 & 48.0 & 57.9 & 20.0 & 8.1 & 7.3 & 22.2 & 15.2 & 17.3 & 7.7 & 14.4 & 10.7 & 13.0 & 21.8 & 4.5 & 11.0 \\
\hline threshold & 66.3 & 26.4 & 37.3 & 51.4 & 53.4 & 27.5 & 60.0 & 43.3 & 34.6 & 44.5 & 24.0 & 52.1 & 15.8 & 37.3 & 37.8 & 52.2 & 41.4 & 30.0 & 59.0 & 51.9 & 36.4 & 43.0 & 35.8 & 46.3 & 35.8 & 56.2 & 38.8 & 41.3 \\
\hline
\end{tabular}


Table 21 Probit results for facing low work incentives using an absolute threshold in 2017. Note: Standard errors in parentheses. * $\mathrm{p}<0.05 * * \mathrm{p}<0.01 * * * \mathrm{p}<0.001$. Including country-fixed effects. dy/dx refers to the discrete change from the base level. Absolute threshold refers to 75 percent for short-term PTR and 50 percent for long-term PTR and METR. N = 212,607. Source: own calculations using EUROMOD version H1.0

\begin{tabular}{|c|c|c|c|c|c|c|c|c|c|c|c|c|}
\hline \multirow[b]{3}{*}{ Men } & \multicolumn{6}{|c|}{ Coefficients } & \multicolumn{6}{|c|}{ Marginal effects (dy/dx) } \\
\hline & \multicolumn{2}{|c|}{ A. Short-term PTR } & \multicolumn{2}{|c|}{ B. Long-term PTR } & \multicolumn{2}{|c|}{ C. METR } & \multicolumn{2}{|c|}{ A. Short-term PTR } & \multicolumn{2}{|c|}{ B. Long-term PTR } & \multicolumn{2}{|c|}{ C. METR } \\
\hline & 0.000 & (.) & 0.000 & (.) & 0.000 & (.) & 0.000 & (.) & 0.000 & (.) & 0.000 & (.) \\
\hline Women & $-0.040^{* * *}$ & $(0.000)$ & $-0.122^{* * *}$ & $(0.000)$ & $0.018^{* * *}$ & $(0.000)$ & $-0.010^{* * *}$ & $(0.000)$ & $-0.028^{* * *}$ & $(0.000)$ & $0.004^{* * *}$ & $(0.000)$ \\
\hline$<30$ & 0.000 & (.) & 0.000 & (.) & 0.000 & (.) & 0.000 & (.) & 0.000 & (.) & 0.000 & (.) \\
\hline $30-50$ & $0.310^{* * *}$ & $(0.000)$ & $-0.036^{* * *}$ & $(0.000)$ & $0.162^{* * *}$ & $(0.000)$ & $0.071^{* * *}$ & $(0.000)$ & $-0.009 * * *$ & $(0.000)$ & $0.033^{* * *}$ & $(0.000)$ \\
\hline $50+$ & $0.354^{* * *}$ & $(0.000)$ & $-0.227^{* * *}$ & $(0.000)$ & $0.036^{* * *}$ & $(0.000)$ & $0.082^{* * *}$ & $(0.000)$ & $-0.051^{* * *}$ & $(0.000)$ & $0.007^{* * *}$ & $(0.000)$ \\
\hline low-skilled & 0.000 & (.) & 0.000 & (.) & 0.000 & (.) & 0.000 & (.) & 0.000 & (.) & 0.000 & (.) \\
\hline medium-skilled & $-0.067^{* * *}$ & $(0.000)$ & $-0.048^{* * *}$ & $(0.000)$ & $-0.026^{* * *}$ & $(0.000)$ & $-0.016^{* * *}$ & $(0.000)$ & $-0.011^{* * *}$ & $(0.000)$ & $-0.006^{* * *}$ & $(0.000)$ \\
\hline high-skilled & $-0.102^{* * *}$ & $(0.000)$ & $-0.131^{* * *}$ & $(0.000)$ & $-0.067^{* * *}$ & $(0.000)$ & $-0.025^{* * *}$ & $(0.000)$ & $-0.031^{* * *}$ & $(0.000)$ & $-0.014^{* * *}$ & $(0.000)$ \\
\hline employed & 0.000 & (.) & 0.000 & (.) & 0.000 & (.) & 0.000 & (.) & 0.000 & (.) & 0.000 & (.) \\
\hline self-employed & $-0.687^{* * *}$ & $(0.000)$ & $0.473^{* * *}$ & $(0.000)$ & $0.153^{* * *}$ & $(0.000)$ & $-0.148^{* * *}$ & $(0.000)$ & $0.123^{* * *}$ & $(0.000)$ & $0.034^{* * *}$ & $(0.000)$ \\
\hline main earner & 0.000 & (.) & 0.000 & (.) & 0.000 & (.) & 0.000 & (.) & 0.000 & (.) & 0.000 & (.) \\
\hline secondary earner & $0.031^{* * *}$ & $(0.000)$ & $-0.611^{* * *}$ & $(0.000)$ & $-0.303^{* * *}$ & $(0.000)$ & $0.007^{* * *}$ & $(0.000)$ & $-0.134^{* * *}$ & $(0.000)$ & $-0.061^{* * *}$ & $(0.000)$ \\
\hline full-time & 0.000 & (.) & 0.000 & (.) & 0.000 & (.) & 0.000 & (.) & 0.000 & (.) & 0.000 & $()$. \\
\hline part-time & $-0.120^{* * *}$ & $(0.000)$ & $-0.128^{* * *}$ & $(0.000)$ & $0.119^{* * *}$ & $(0.000)$ & $-0.028^{* * *}$ & $(0.000)$ & $-0.029^{* * *}$ & $(0.000)$ & $0.026^{* * *}$ & $(0.000)$ \\
\hline Q1 & 0.000 & (.) & 0.000 & (.) & 0.000 & (.) & 0.000 & (.) & 0.000 & (.) & 0.000 & $()$. \\
\hline Q2 & $-0.031^{* * *}$ & $(0.000)$ & $-0.057^{* * *}$ & $(0.000)$ & $-0.175^{* * *}$ & $(0.000)$ & $-0.008^{* * *}$ & $(0.000)$ & $-0.016^{* * *}$ & $(0.000)$ & $-0.038^{* * *}$ & $(0.000)$ \\
\hline Q3 & $-0.210^{* * *}$ & $(0.000)$ & $-0.310^{* * *}$ & $(0.000)$ & $-0.406^{* * *}$ & $(0.000)$ & $-0.051^{* * *}$ & $(0.000)$ & $-0.083^{* * *}$ & $(0.000)$ & $-0.080^{* * *}$ & $(0.000)$ \\
\hline Q4 & $-0.162^{* * *}$ & $(0.000)$ & $-0.576^{* * *}$ & $(0.000)$ & $-0.120^{* * *}$ & $(0.000)$ & $-0.040^{* * *}$ & $(0.000)$ & $-0.142^{* * *}$ & $(0.000)$ & $-0.027^{* * *}$ & $(0.000)$ \\
\hline Q5 & $-0.261^{* * *}$ & $(0.000)$ & $-0.793^{* * *}$ & $(0.000)$ & $0.085^{* * *}$ & $(0.000)$ & $-0.063^{* * *}$ & $(0.000)$ & $-0.182^{* * *}$ & $(0.000)$ & $0.020^{* * *}$ & $(0.000)$ \\
\hline non-poor & 0.000 & $()$. & 0.000 & $()$. & 0.000 & (.) & 0.000 & (.) & 0.000 & (.) & 0.000 & (.) \\
\hline poverty risk & $0.635^{* * *}$ & $(0.000)$ & $0.640^{* * *}$ & $(0.000)$ & $0.329^{* * *}$ & $(0.000)$ & $0.165^{* * *}$ & $(0.000)$ & $0.175^{* * *}$ & $(0.000)$ & $0.077^{* * *}$ & $(0.000)$ \\
\hline low risk of UE & 0.000 & (.) & 0.000 & (.) & 0.000 & (.) & 0.000 & (.) & 0.000 & (.) & 0.000 & (.) \\
\hline high risk of UE & $-0.095^{* * *}$ & $(0.000)$ & $0.140^{* * *}$ & $(0.000)$ & $0.188^{* * *}$ & $(0.000)$ & $-0.022^{* * *}$ & $(0.000)$ & $0.034^{* * * *}$ & $(0.000)$ & $0.042^{* * *}$ & $(0.000)$ \\
\hline Pseudo R-squared & & & 0.1 & & & & & & & & & \\
\hline
\end{tabular}

